\title{
Crandallite-rich beds of the Libkovice Member, Most Basin, Czech Republic: climatic extremes or paleogeographic changes at the onset of the Miocene Climatic Optimum?
}

\author{
Karel Mach ${ }^{1} \quad$ Vladislav Rapprich $^{2} \quad$ Martin Faměra $^{3,6} \quad$ Martina Havelcová $^{4} \quad$ Tomáš Matys Grygar $^{3} \quad$ Tomáš Novotný1 $^{1}$ \\ Michal Řehoř ${ }^{5}$ Yulia V. Erban Kochergina ${ }^{2}$
}

\author{
'Severočeské doly a.s. \\ Doly Bílina, ul. 5. Května 213, 41829 Bílina, Czech Republic \\ ${ }^{2}$ Czech Geological Survey \\ Klárov 3, 11821 Prague, Czech Republic \\ ${ }^{3}$ Institute of Inorganic Chemistry of the Czech Academy of Sciences \\ 25068 Řež, Czech Republic
}

${ }^{4}$ Institute of Rock Structure and Mechanics of the Czech Academy of Sciences

Klárov 3, 11821 Prague, Czech Republic

${ }^{5}$ Brown Coal Research Institute, Inc.

tř. Budovatelů 2830/3, 43401 Most, Czech Republic

${ }^{6}$ Department of Geology, Faculty of Science

Palacký University, 17. Listopadu 1192/12, 77146 Olomouc, Czech Republic

\begin{abstract}
We describe the occurrence and possible origin of rare beds $1-10 \mathrm{~cm}$ thick and containing $20-70 \%$ of crandallite, a Ca-Al phosphate enriched in $\mathrm{Sr}$ and $\mathrm{Ba}$, found within otherwise monotonous clay-rich lacustrine sediments of the Most Basin in the Central-European Neogene Ohře Rift system. The beds were formed at ca. 17.31, 17.06, and $16.88 \mathrm{Ma}$, while the entire suite of monotonous clays of the Libkovice Member was deposited between 17.46 and 16.65Ma. Trace-element and organic geochemistry, Ar-Ar geochronology and C-O-Sr isotope systematics are used to infer their source and processes leading to their formation. The most enigmatic aspect of the formation of the crandallite beds is the removal of a huge amount of phosphorus from its biogenic cycle in the lacustrine system, which was otherwise stable for ca. $0.8 \mathrm{My}$. Formation of detritus-poor crandallite beds could result from some exceptional environmental disruptions that hindered transport of fine clastic material to the basin floor. Silicic volcanic activity in the area of the Pannonian Basin could have triggered this disruption. Crandallite could provide evidence of long-lasting droughts and acidification of the exogenic environment, as they are roughly coeval with the onset of the Miocene Climatic Optimum at ca. 17.0Ma.
\end{abstract}




\section{INTRODUCTION}

This paper deals with phosphate-rich beds found within the Lower Miocene lacustrine fill of the continental Most Basin within the Eger Rift in Central Europe (Matys Grygar and Mach, 2013; Matys Grygar et al., 2014, 2017; Fig. 1). The main mineral component of these beds is $\mathrm{Sr}$ - and $\mathrm{Ba}-$ rich $\mathrm{Ca}-\mathrm{Al}$ phosphate of the crandallite group $\left(\mathrm{CaAl}_{3}\left(\mathrm{PO}_{4}\right)\right.$ $\left.\left(\mathrm{PO}_{3} \mathrm{OH}\right)(\mathrm{OH})_{6}\right)$ (Novák et al., 1993). Widespread beds containing crandallite intercalated in otherwise monotonous siliciclastic lacustrine sediments have not been described elsewhere, and the mechanism of their formation is thus not well constrained.

The occurrence of $\mathrm{Ca}-\mathrm{Al}$ phosphates is commonly limited to weathering crusts, altered volcanic rocks, and very specific sedimentary environments (Dill, 2001). They were described as a finely dispersed admixture in tonsteins within coal-bearing units (Kokowska-Pawlovska and Nowak, 2012; Muszyński and Wyszomirski, 1998), kaolinite-bearing altered tuffs (Triplehorn and Bohor, 1983), or fluvial sandy sediments (Borruel-Abadía et al., 2016; Pe-Piper and Dolansky, 2005; Spötl, 1990). Autochthonous phosphates of the crandallite-group in paleosols and fluvial sediments were attributed to early diagenetic alteration of calcium phosphates and $\mathrm{Al}$ sources by percolating acidic meteoric water (Bauluz et al., 2014; Spötl, 1990; Pe-Piper and Dolansky, 2005). Such formation of crandallite in fluvial sediments was assigned to global acidification of the exogenic environment during biotic crises (Borruel-Abadía et al., 2016, 2019). The $\mathrm{P}_{2} \mathrm{O}_{5}$ content in rock formations with crandallite admixture is maximally $6 \mathrm{wt} . \%$, but concentrations less than $1 \mathrm{wt} . \%$ are more common (Kokowska-Pawlowska and Nowak, 2012). Extreme contents of $\mathrm{P}_{2} \mathrm{O}_{5}$ exceeding 20wt.\% in early Miocene sediments of the Most Basin from lacustrine clays forming the coal seam overburden (Coufal and Mejstříková, 1996; Matys Grygar and Mach, 2013; Novák et al., 1993) is the topic of this contribution.

The crandallite beds $(\mathrm{C \#})$ in the Most Basin are found at the base of certain $\mathrm{K}$-concentration minima within lacustrine clays of the Libkovice Member pointing to onsets of periods of more intensive chemical weathering in the watershed (Matys Grygar et al., 2019a). Because the $\mathrm{K}$-concentration minima in the Most Basin were orbitally paced (Matys Grygar et al., 2014, 2017, 2019b), we hypothesize that Crandallite beds manifest some special environmental conditions related to the climatic cyclicity. The aim of characterizing environmental changes during sedimentation of the Most Formation is motivated by insufficient knowledge of what triggered the Miocene Climatic Optimum that started around 17.0Ma (Holbourn et al., 2015). The individual $\mathrm{C \#}$ are present as outcrops in opencast mines and drill cores have been systematically sampled and documented since 2009. The geochemical research of surrounding clays was carried out concurrently and already published (Matys Grygar et al., 2014). This paper summarizes both new and previously published knowledge we have gathered on these beds resulting in an interpretation of their origin.

\section{STUDY AREA AND MATERIALS}

\section{Geological background}

The Most Basin (Fig. 1A) is the largest sedimentary basin in the Oligocene to early Miocene tectonic structure of the Ohře Rift (Eger Graben) in the north-western part of the Bohemian Massif (Kasinski, 1991; Rajchl et al., 2009). The basement of the basin is formed by Late Proterozoic gneisses, Carboniferous felsic magmatic rocks (AltenbergTeplice Volcanic Complex) and Late Cretaceous marine sediments (mainly sandstone, limestones and marlstones). Basin filling began with the Oligocene volcanogenic Střezov Formation, an equivalent of exposed rocks of the České Středohoří and Doupovské Hory volcanic complexes surrounding the Most basin from the SE and W. Both are represented by alkaline basalts, basanites, tephrites and various trachytic rocks. The Miocene fill is formed by the Most Formation, subdivided into the Oligocene/Miocene transitional Duchcov Member, the main coal seam-bearing Holešice Member, monotonous lacustrine clays of the Libkovice Member, variegated Lom Member containing so-called Lom Seam on its top, and the youngest lacustrine clays of the Osek Member (Fig. 1D). Clastic parts of the Most Formation have been formed by sedimentation of locally-sourced weathered material (the Krušné Hory Mts., the České Středohoří Mts., and the Doupovské Hory Mts.) as well as more distal sources in the south-west of the Bohemian Massif (Fig. 1C), as revealed by evaluation of heavy minerals associations (Mach et al. 2014). According to this research of heavy minerals, older basin sediments were formed by the end of the Oligocene and beginning of the Miocene from local weathering products of volcanic rocks in České Středohoří and Doupovské Hory mountains together with Proterozoic and Paleozoic metamorphic formations and the Carboniferous felsic magmatic rocks. Sedimentation occurred in a fluvial environment, showing a gradual spreading of the river floodplains. The esediment routing system extended from catchments areas in the SW part of Bohemian Massif to the marine depositional environments of the Leipzig bay of the Miocene North Sea. Later, local sources of clastic material on the floodplain were gradually covered by expanding peat-forming swamp and more distally-transported material from Proterozoic and Paleozoic metamorphic formations in the south-western part of the Bohemian Massif with an admixture of the marine Cretaceous sediments from areas east of the Most Basin 

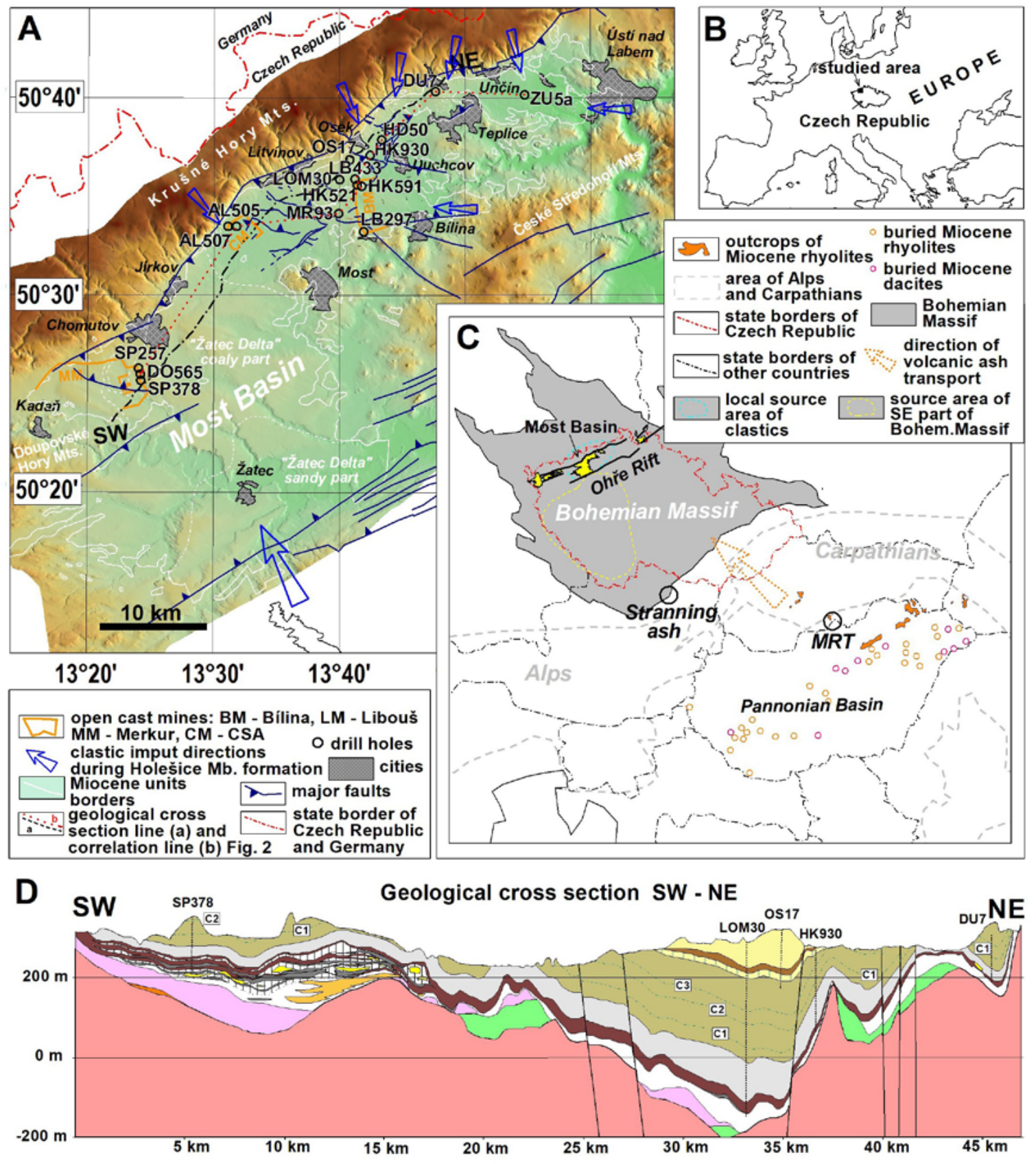

\begin{tabular}{|c|c|c|c|c|}
\hline \multicolumn{2}{|c|}{ Miocene, Most Formation: } & $\begin{array}{l}\text { Holešice Member } \\
\text { main coal seam, coal }\end{array}$ & \multicolumn{2}{|c|}{ Older formations: } \\
\hline & $\begin{array}{l}\text { Osek Member } \\
\text { clay }\end{array}$ & $\begin{array}{l}\text { Holešice Member } \\
\text { coaly claystones, coal }\end{array}$ & & $\begin{array}{l}\text { Eocene } \\
\text { sandstone }\end{array}$ \\
\hline & $\begin{array}{l}\text { Lom Member } \\
\text { coaly claystones, coal }\end{array}$ & $\begin{array}{l}\text { Holešice Member } \\
\text { clays within coal seam }\end{array}$ & & $\begin{array}{l}\text { Oligocene - Střezov Formation } \\
\text { alcaline volcanites }\end{array}$ \\
\hline & $\begin{array}{l}\text { Lom Member } \\
\text { clays }\end{array}$ & $\begin{array}{l}\text { Holešice Member } \\
\text { sands }\end{array}$ & & $\begin{array}{l}\text { Cretaceous } \\
\text { limestone, sandstone }\end{array}$ \\
\hline & $\begin{array}{l}\text { Libkovice Member } \\
\text { clays + C layers }\end{array}$ & $\begin{array}{l}\text { Duchcov Member } \\
\text { sands }\end{array}$ & & $\begin{array}{l}\text { basement - Proterozoic gneisses, } \\
\text { acid Carboniferous magmatites }\end{array}$ \\
\hline & $\begin{array}{l}\text { Holešice Member } \\
\text { clays }\end{array}$ & $\begin{array}{l}\text { Duchcov Member } \\
\text { clays }\end{array}$ & a b & a) faults, b) drill holes \\
\hline
\end{tabular}

FIGURE 1. A) Map of the Most Basin, B) position of the study area within Europe, C) map of potential volcanic sources of basal quartz + biotite sandy laminae. MRT: Middle Rhyolite tuff after Roetzel et al., 2014; buried acid volcanic centers after Zelenka et al., 2004, D) geological cross section SW-NE. 
gradually became more prevalent. Within the layer of peat, this clastic alluvial input formed a widespread accumulation of sandy clay intercalations locally called the Žatec Delta (Fig. 1A). Geochemistry and mineralogical composition of associated clays correspond with the described heavy mineral associations. Peat accumulation was gradually declining as clastic input increased to the Bílina area, where a local lake was formed with fast sedimentation supported by peat compaction. This lake together with others lakes covered the entire area of the basin in stepwise fashion and started the lacustrine stage of the basin development (Mach et al. 2014). Heavy minerals of the Libkovice Member formed by this basin-wide lake are inaccessible, because only fine sediments have been preserved from the lacustrine phases, however the chemical composition of the Libkovice Member is comparable with the uppermost clays of the Holešice Member (the Břešt'any clay). The clays within the Most Formation should be classified as silty clays, because of considerable and variable contents of quartz silt dispersed in the clay. More significant for the $200 \mathrm{~m}$ thick Libkovice Member is the difference in the mineralogical composition, that can be attributed to the spreading and deepening of the lake during the deposition of this member (Matys Grygar and Mach, 2012). This change created distinct sedimentary conditions and led to more pronounced grain-size sorting expressed not only by variable content of silt but also by composition of clay minerals. Typical kaolinite or kaoliniteillite clay composition of the Holešice Member was replaced by sedimentation of kaolinite-illite-illite-smectite composition during the Libkovice Member formation. Hypothesis of considerable paleoenvironmental change during the Libkovice Member formation is supported by differences in the dispersed organic matter composition between the Holešice and the Lom members on one hand and the Libkovice Member on the other hand. Havelcová et al. (2015) found a higher proportion of liptinite macerals, mainly alginite (from algae) against huminite macerals (from plant detritus) in the Libkovice Member clays comparing to the Holešice Member. A climatically driven weathering regime in the basin catchment of South-western part of the Bohemian Massif led to the variability of material eroded and transported to local lacustrine reservoirs within peatforming swamp and then to a single basin-wide lake over the former peat swamp. This seemingly inconspicuous cyclic variability in geochemical composition could be used to date the sedimentary sequence by means of cyclostratigraphy in combination with magnetostratigraphy (Matys Grygar et al., 2014, 2017). Shallowing of the Libkovice Lake and changes in the distributary network of the alluvial system led first to the return of kaolinite-illite clay sedimentation (15-20m thick) and then to transition from lacustrine to swamp environments on its northern border. The product of swampy conditions is now represented by the so-called Lom Coal Seam, a 15m thick part of the Lom Member (Figs. 1D; 2). The top of the sedimentary profile was formed in renewed lacustrine conditions. This stage is represented by silty clays of the Osek Member similar to the Libkovice one.

Authigenic minerals represent substantial components of the basin fill together with clay minerals and quartz silt or sand. They have either dispersed, concretional, or thin layer forms that occur within all sedimentary units of the Most Formation. Commonly, these minerals are represented by carbonates of the siderite-ankerite-dolomite-calcite series, and by pyrite or marcasite. Most of these minerals were formed by bacterial processes of sulphate reduction or methanogenesis (Mach et al., 1999, 2001).

The evolution of the Most Basin was described by Rajchl et al. (2009). The majority of the basin fill was formed during the initial S-N extension regime in four basic subdepocenters divided by E-W trending faults. Finally, there was a change to NW-SE extension, which led to interruption of sedimentary filling of the basin and formation of present system of SW-NE trending fault system. The Most Basin was a hydrologically open, overfilled basin through its time of filling, because there are no signs of dry periods leading to aerial exposure of the lake bottom such as in the nearby Sokolov Basin of the same age (Rojík, 2004). Even during peat-forming periods, input of water to the basin was in equilibrium with output. This is documented by continuing transfer of Bohemian Massif clastic material to the area of Germany (Mach et al., 2014).

\section{Crandallite in the Most Formation}

In the Most Formation phosphates were accumulated in form of layers with thicknesses of a few $\mathrm{cm}$ (crandallite layers or beds) or in the form of phosphate-rich concretions. The latter are known from the Holešice Member, in particular in the clay partings of the Main Coal Seam in the Chomutov area (Novotný and Mach, 2017) but they are not described in this work. Crandallite beds are a volumetrically minor, but very specific part of the Libkovice Member (Fig. 2). The Libkovice Member includes monotonous lacustrine silty clays with a significant portion of clay minerals with smectite structures. Several laterally-continuous crandallite-rich beds, each with thicknesses of 0.5 to several $\mathrm{cm}$, have a specific stratigraphic position within sediment chemostratigraphy, developed by paleomagnetic dating and cyclostratigraphy (Matys Grygar et al., 2014, 2017), i.e. they were formed coevally on the paleolake bottom. The crandallite-rich layers are overlaid by sediments with clear $\mathrm{Sr}$ concentration minima, these both are located in the bottom part of the K-concentration minima identified in the entire basin floor (Matys Grygar and Mach, 2013) (Figs. $2 ; 3)$. The composition of the crandallite-rich beds was first studied in the Merkur and Libouš coal mines in the western part of the basin (Coufal and Mejstříková, 1996; Novák et al., 1993). According to these previous investigations, 


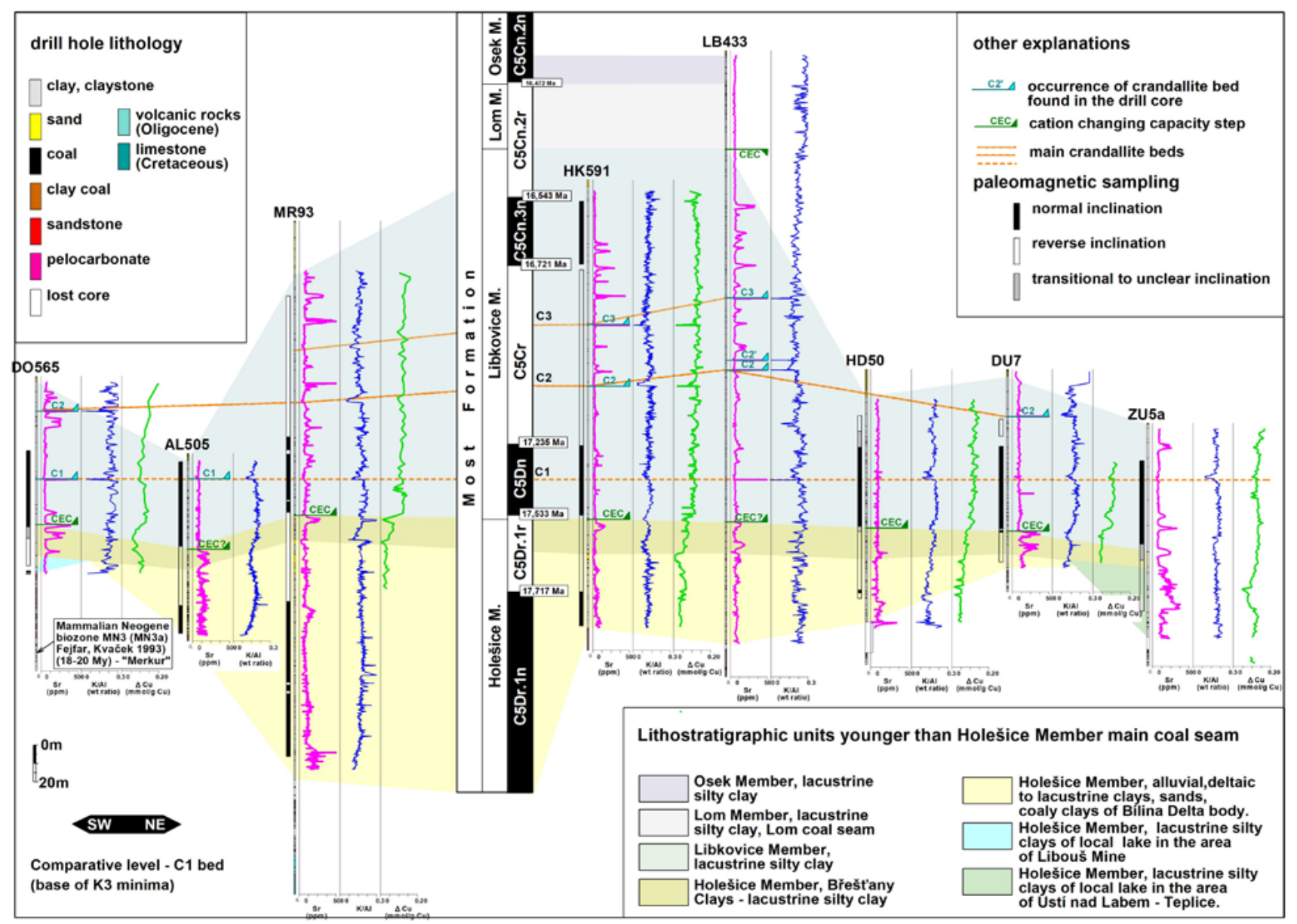

FIGURE 2. General correlation scheme of drillholes through the Most Basin along a W-E transect, with highlighted positions of Crandallite beds within Libkovice Member. This scheme was constructed according to early published data on litho- chemo- and magnetostratigrafic subdivision of the Most Formation (according to Matys Grygar et al., 2019).

it consists of $\mathrm{Ca}-\mathrm{Al}$ phosphate with some other mineral admixtures. Usually, the phosphate is defined as a $\mathrm{Sr}$-, Ba-rich crandallite, a member of isomorphous series of crandallite-goyazite-gorceixite minerals. The crandallite bed contains up to $70 \%$ of phosphate, a significant portion of which can consist of metastable $\mathrm{SiO}_{2}$ polymorphs, mainly cristobalite and tridymite (Novák et al., 1993) and clay minerals (kaolinite, illite). There are three prominent crandallite-rich beds within the Libkovice Member; they are numbered consecutively $\mathrm{C \#}$ (C1-C3) in an upward direction (Matys Grygar and Mach, 2013; Matys Grygar et al., 2014). Several other not-so-striking occurrences have been found later. These were labelled $\mathrm{C} 1 \mathrm{a}$ and $\mathrm{C} 2 \mathrm{a}$, the latter divided to $\mathrm{C} 2$ ' and $\mathrm{C} 2$ ".

During detailed geochemical research it has been found that not only centimeter thick $\mathrm{C \#}$ beds contain crandallite. Dispersed crandallite particles result in anomalously high contents of $\mathrm{Sr}, \mathrm{Ba}$ and $\mathrm{P}$ in layers of clays with several meter thicknesses, typically with $\mathrm{Sr}$ concentrations of 100-350ppm $\mathrm{Sr}$ in comparison to ca. 50-70ppm base concentrations, i.e. ca. $2-5$ times above the background (Fig. $3)$. These anomalies are correlated over 20-80 kilometers between drill cores (Fig. 2) within the topmost parts of the Holešice Member and the Libkovice Member clays (Matys Grygar et al., 2017). Even so, this anomalous $\mathrm{Sr} / \mathrm{Ba} / \mathrm{P}$ content is two orders of magnitude lower than in $\mathrm{C \#}$ beds. In the Libkovice Member clays, elevated Sr concentrations correlate with elevated $\mathrm{Al} / \mathrm{Si}$ (Fig. 3), corresponding with stages of higher supply of kaolinite clay minerals in relation to silt-sized quartz grains. As a result of this correlation, higher $\mathrm{Sr} / \mathrm{Ba} / \mathrm{P}$ content is well displayed by cation changing capacity curve (minima) and a geophysical log of electric induction (minima). All these features and methods show a specific composition of the clay content and mineralogy associated with crandallite (Fig. 3).

\section{Studied sediments}

A complete correlation scheme of drill hole profiles down the Most Basin longitudinal axis (Figs. 1; 2) shows relations of lithostratigraphic units above than 


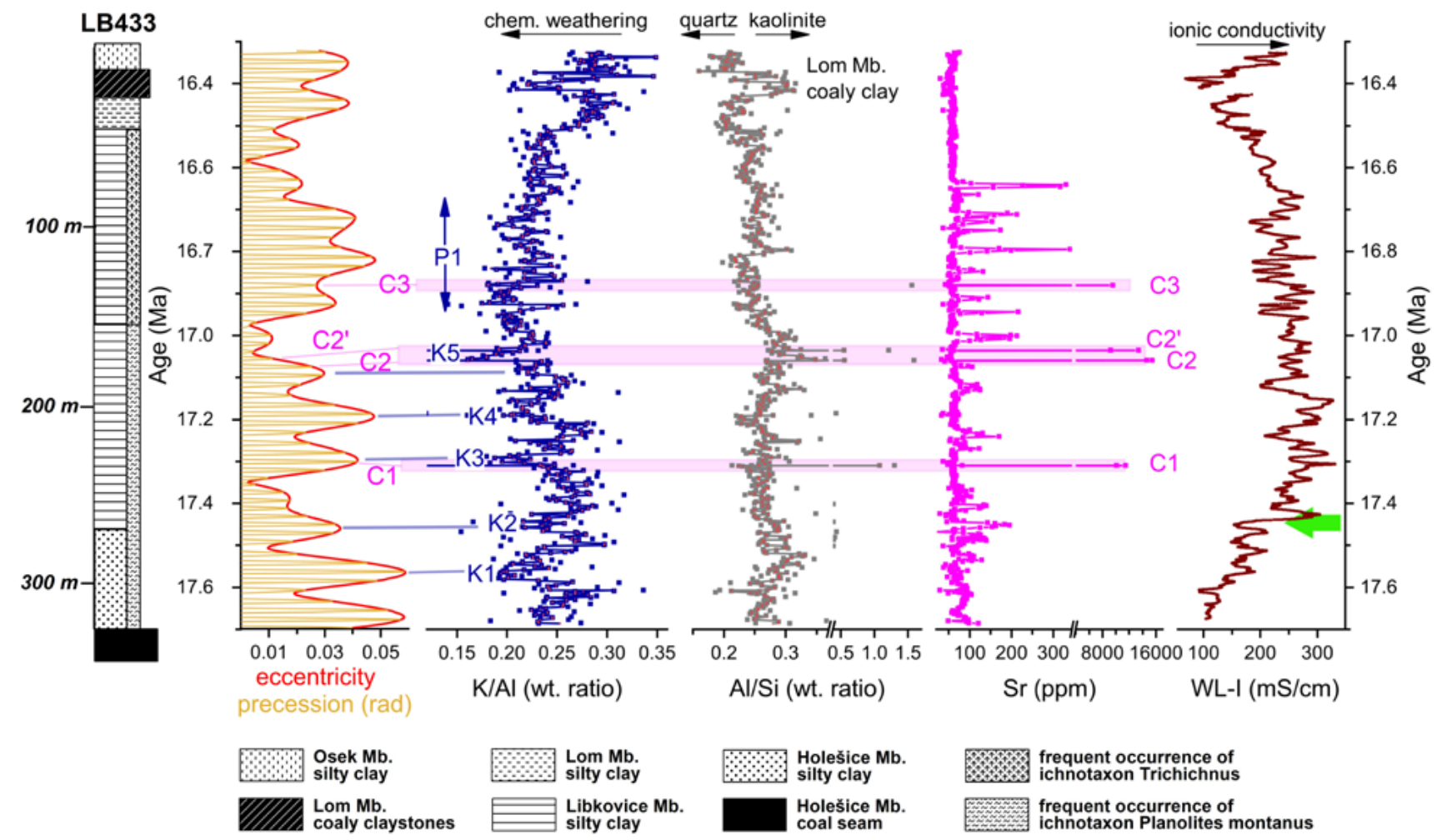

FIGURE 3. Simplified LB433 borehole profile with important geochemical characteristics and age model. Positions of C\# beds are located by Sr extremes.

main coal seam together with magnetic polarity and chemostratigraphic horizons. As a representative profile, the LB433 drill hole from the central part of the basin was chosen (Fig. 3). The depth-age model for the LB433 core was obtained by matching $\mathrm{K}$ minima to the orbital eccentricity maxima as described earlier by Matys Grygar et al. (2019b). The depth-age model is based on integrated stratigraphy based on biostratigraphy, magnetic polarity, and cyclostratigraphy, corroborated and validated by extensive lateral correlation of sediment cores (Matys Grygar et al.,2014, 2017, 2019b). The primary age model for LB433 was obtained by alignment to the stratigraphic scheme published in Matys Grygar et al. (2019b). The profile of LB433 borehole consists of all known stratigraphic units of the Most Basin younger than the main coal seam of the Holešice Member. Profile starts from the $18 \mathrm{~m}$ thick upper half of main coal seam. Then starts clayey part of the profile by $65 \mathrm{~m}$ of clays of Holešice Member local Bílina lake. Younger monotonous clays of the Libkovice Member reach 204m. Libkovice Member clays are usually gray. As it is usual on the central part of the basin, clays of the Libkovice Member are fossil barren, but we can distinguish ichnofossils representing some token of lacustrine life. Two sub-units can be distinguished in the Libkovice member profile, the lower half frequently bioturbated by Planolites montanus borings (Mikuláš et al., 2006) and the upper half with abundant occurrence of sulphidic hairy structures related to "Trichichnus" ichnofossils (Kedzierski et al., 2015). Dense, 0.5-2mm in diameter tube-like formations, Planolites montanus (Mikuláš et al., 2006) are interpreted as domichnia of unknown small unvertebrates. Their occurrence points at more oxic conditions in top 1-2 $\mathrm{cm}$ of the lake bottom mud. On the contrary thin pyritic hairy fibers, "fossilized bioelectric wires" of Trichichnus (Kedzierski et al., 2015) are interpreted as a product of bacterial activities in the oxygen-depleted part of sediments and so they are related nearly to at least temporary anoxic conditions on the surface of bottom sediment. Libkovice Member hosts $\mathrm{C \#}$ beds. A typical feature of $\mathrm{C \#}$ beds occurrences within outcrops in open cast mines is a contrast of the color of clays on either side of thin C\# beds (Fig. 4). Mineralogical and geochemical differences lead to the darker gray color of underlying clay and light gray color of the overburden. The overburden layers commonly display better visible layering and seem lighter within several meters thickness (Fig. 4). In the case of $\mathrm{C} 1$ in the Libouš Mine this lighter overburden clay is even fossiliferous (unpublished association of macroflora with rare insect imprints) unlike the uniform fossil-barren Libkovice Member.

The subsequent $18 \mathrm{~m}$ of the Most Formation in the LB433 profile are represented by clays of lacustrine Lom Member clays and $17 \mathrm{~m}$ of the Lom Member Coal Seam. The top of the profile is formed by $15 \mathrm{~m}$ of the Osek Member 
lacustrine clays. Neither of these units contain similar occurrences of phosphate like the Libkovice Member.

\section{METHODS}

We used a variety of methods to describe the extraordinary phosphate occurrences, their specifics within the Holešice and Libkovice members and thereby searched for evidence of their origin.

\section{Microscopic description and mineral chemistry}

Twenty $2 \times 3 \mathrm{~cm}$ petrographic thin sections were prepared at the Czech Geological Survey in Prague (CGS). The sections represented the majority of $\mathrm{C} \#$ beds, in both horizontal and vertical directions. The textures, structures, granularity, and mineral composition of the beds were studied. Five polished sections were also prepared from the $\mathrm{C} 1$ bed in the Libouš Mine. The sections were used to study the chemical composition of individual clasts, crystals or amorphous phases using a JEOL JxA-8600 electron microprobe equipped with SE (Secondary Electron), BSE (BackScattered Electron), EDS (Energy-Dispersive X-ray Spectroscopy) and WDS (Wavelength-Dispersive X-Ray Spectroscopy) detectors housed at the Dept. of Geology, Faculty of Science, Palacký University in Olomouc. An accelerating voltage of $15 \mathrm{kV}$, beam current of $10 \mathrm{nA}$ and counting time of 100 s were used for analysis of silicates and oxides. The following standards were used: jadeite $(\mathrm{Na})$, barite $(\mathrm{Ba})$, apatite $(\mathrm{P})$, diopside $(\mathrm{Mg}, \mathrm{Ca})$, microcline $(\mathrm{Si}, \mathrm{K}, \mathrm{Al})$, elemental manganese $(\mathrm{Mn})$, magnetite $(\mathrm{Fe})$, sphalerite $(\mathrm{S}, \mathrm{Zn})$, albite (Na), ilmenite (Ti). Chemical composition of biotite crystals from the sandy basis of the $\mathrm{C} 2$ bed sampled at Bílina and Tušimice mines, together with biotite flakes from the Sokolov Basin (Rojík, 2004) were studied separately using the Tescan MIRA 3GMU Field Emission Gun-equipped Scanning Electron Microscope (FEG-SEM), housed at the CGS, equipped with the X-Max 20 (Oxford Instruments) EDS microanalysis system to avoid preferential evaporation of alkali elements from the matrix (cf. WDS). EDS analyses were conducted with an accelerating voltage of $15 \mathrm{kV}$, beam current of $3 \mathrm{nA}$ and the working distance of $15 \mathrm{~mm}$. For quantitative EDS analyses, the SPI set of mineral standards was used for standardization, pure Co for quant optimization.

\section{Chemical and mineralogical composition}

Selected samples of the parts of the C\# beds richest in crandallite and also sandy bases of the beds were collected for bulk-rock chemical analyses. Conventional wet chemical analyses (major elements) were provided by laboratories of the CGS. Trace element concentrations (including Rare-Earth Elements (REEs) were determined using the ThermoFisher Scientific $X$ Series II ICP-MS
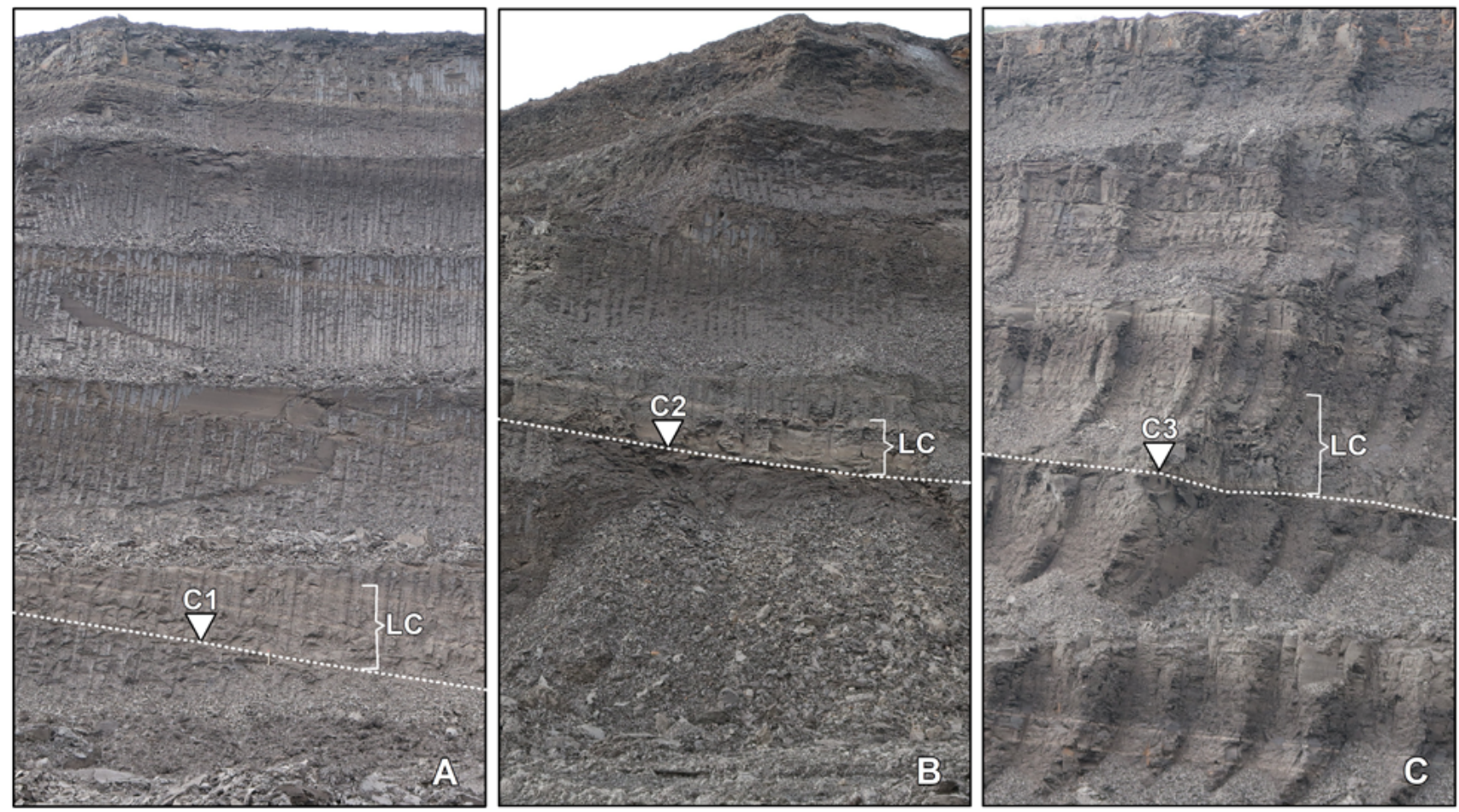

FIGURE 4. Position of main C\# beds in the Libkovice Member profile, Bílina Mine overburden faces. Notice the darker clays bellow C\# beds an several meters thick lighter layers (marked as LC) above them. Lighter layers above C\# beds represent K-minima. Height of profiles approximately 20 m. Note high degree of similarity of these photos notwithstanding that the stratigraphic position of individual beds differs in tens meters. 
(mass spectrometry with inductively coupled plasma; Ba, $\mathrm{Cr}, \mathrm{Ga}, \mathrm{Hf}, \mathrm{Nb}, \mathrm{Ni}, \mathrm{Pb}, \mathrm{Rb}, \mathrm{Sr}$, Th, U, Zr, Y, REEs) housed at the CGS. For the ICP-MS determinations, the samples were decomposed fusion with $\mathrm{LiBO}_{2}-\mathrm{Na}_{2} \mathrm{CO}_{3}$ mixture in a Pt-beaker.

Mineral composition of 18 representative samples was determined semi-quantitatively by conventional powder X-Ray Diffraction (XRD). The majority of these samples (14) were analyzed in the Brown Coal Research Institute accredited according to ČSN EN ISO/IEC 17025. Analyses of powder samples were realized using a D 5000 Siemens diffractometer and evaluated with the DIFFRAC plus EVA application. Part of the software is database "Powder Diffraction File" (PDF) updated by the International Centre for Diffraction Data (ICDD). The main analytical parameters were: acquisition time 1 hour, angular spectrum $3 \div 80^{\circ} 2 \theta$ detector slit $0.2 \mathrm{~mm}$, primary X-rays slit $2 \mathrm{~mm}$, secondary X-rays slit $2 \mathrm{~mm}$, angular step $0.02^{\circ}$.

Composition of additional four samples was analyzed semi-quantitatively in laboratories of the CGS. Powder $\mathrm{X}$-ray diffraction data were here collected in BraggBrentano geometry on a Bruker D8 Advance diffractometer equipped with a LynxEye XE detector and Soller slits $\left(2.5^{\circ}\right)$ in primary and secondary beams. $\mathrm{CuK} \alpha$ radiation was used. The samples mixed with acetone were gently pulverized in an agate mortar. The data were collected in an angular range from 4 to $80^{\circ}$ of $2 \theta$, with a $0.015^{\circ}$ step and counting time of 0.8 sec. per step. Qualitative phase analysis was performed using the DIFFRAC. Eva (Bruker AXS, 2015) program and the PDF-2 database (ICDD, 2002). Subsequent quantitative phase analysis was carried out by the Rietveld method using the Topas 5 (Bruker AXS, 2014) program. Crystal structure models for the detected phases were adapted from the Inorganic Crystal Structure Database (Zagorac et al., 2019).

\section{Analysis of $\mathrm{C}$ and $\mathrm{O}$ stable isotopes}

Compositions of stable $\mathrm{C}$ and $\mathrm{O}$ isotopes in carbonates (siderite) in the sediment and the $\mathrm{C} \#$ beds ( $\mathrm{C} 1$ from the Libouš Mine) were examined at the CGS. Stable isotope composition of carbon $\left(\delta^{13} \mathrm{C} \%\right.$ ) and oxygen $\left(\delta^{18} \mathrm{O} \% \mathrm{)}\right.$ ) in samples of siderite was determined in $\mathrm{CO}_{2}$ gas produced by the decomposition of the sample in $100 \%$ phosphoric acid under vacuum condition, at the temperature of $100^{\circ} \mathrm{C}$ for 24 hours (Rosenbaum and Sheppard, 1986). The isotopic composition of carbon and oxygen in emitted $\mathrm{CO}_{2}$ gas was measured on Delta V Advantage (ThermoFisher, Bremen, Germany) mass spectrometer. The total error yields $\pm 0.1 \%$. Isotopic composition of carbon is relative to V-PDB international standard. In the case of siderite, the $\delta^{18} \mathrm{O}$ value is corrected by the value +1.44 .

\section{Strontium isotope systematics}

Strontium isotopic composition of the studied sediments as well as of potential source rocks were obtained at the CGS. Silicate samples were dissolved using a combined $\mathrm{HF}-\mathrm{HNO}_{3}-\mathrm{HCl}$ digestion. Carbonate samples were first digested in $\mathrm{HCl}$ and the remaining undissolved silicate residue was dissolved by $\mathrm{HF}-\mathrm{HNO}_{3}-\mathrm{HCl}$; the extracts were combined prior to chromatographic separation. Strontium was isolated from the bulk matrix using Sr. spec resin (Triskem Intl.) (Pin et al., 2014). Isotopic analyses were performed with a Triton Plus (Thermo Fisher Scientific Inc.) thermal ionization mass spectrometer in static mode using a single Ta filament assembly. The measured ${ }^{87} \mathrm{Sr} /{ }^{86} \mathrm{Sr}$ ratios were corrected for mass fractionation assuming ${ }^{86} \mathrm{Sr} /{ }^{88} \mathrm{Sr}=0.1194$. External reproducibility and measurement accuracy were demonstrated by repeated analyses of the NBS $987\left({ }^{87} \mathrm{Sr} /{ }^{86} \mathrm{Sr}=0.710253 \pm 0.000018\right.$ $(2 \sigma, n=54)$ reference material (see Jochum et al., 2005). Analyzed samples represent Miocene phosphates and carbonates, clays with normal and anomalous Sr content, and also by rocks representing potential sediment sources gneisses and acid magmatic rocks of the Krušné Hory Mountains and Cretaceous marls from the Louny area south of the Most Basin. All data, newly acquired and found in the literature, were recalculated to the time of deposition, i.e. 17Ma, based on constraints given by Steiger and Jäger (1977). Sr and Rb concentrations for the samples not analyzed by ICP-MS were obtained using portable XRFanalyzer Niton 3 Gold+ Thermo Fischer Scientific as an average of 5 measurements.

\section{Organic Geochemistry}

Powdered samples $(<0.2 \mathrm{~mm})$ of $\mathrm{C} 1, \mathrm{C} 2$ and $\mathrm{C} 3$ beds and clays surrounding the $\mathrm{C} \#$ beds sampled from the outcrops in the Bílina Mine were extracted using ASE extractor (Dionex) by dichloromethane. Gas chromatography/mass spectrometry (GC/MS) analysis were performed using a Trace 13101310 Gas Chromatography (GC) equipped with an ISQ (In Situ Quantitative) single quadrupole MS (Thermo Scientific) instrument equipped with a TR-5MS column $(60 \mathrm{~m} \times 0.25 \mathrm{~mm} \times 0.25 \mu \mathrm{m})$. The oven temperature program was set to $1 \mathrm{~min}$ step at $40^{\circ} \mathrm{C}$ followed by increase to $120^{\circ} \mathrm{C}$ at rate of $15^{\circ} \mathrm{C} / \mathrm{min}$, than increase to $220^{\circ} \mathrm{C}$ at rate of $6^{\circ} \mathrm{C} / \mathrm{min}$ followed by increase to $300^{\circ} \mathrm{C}$ at $12^{\circ} \mathrm{C} / \mathrm{min}$ and finally $5 \mathrm{~min}$ delay at $300^{\circ} \mathrm{C}$. Samples were injected in splitless mode, the injector temperature was set at $250^{\circ} \mathrm{C}$ and helium was the carrier gas. Mass spectra were obtained by scanning from $\mathrm{m} / \mathrm{z} 45$ to 650 in full scan mode. Aliquots of the total extracts were converted to ester derivatives by reaction with methanol and $14 \%$ boron trifluoride (BF3) for $1 \mathrm{~h}$ at $90^{\circ} \mathrm{C}$ and analyzed under the same conditions. The mass spectrometer detector was operated in the Total Ion Current acquisition mode and was combined with the 
Selected Ion Monitoring acquisition mode for alkanes, and methyl ester fatty acids. For data processing, the Chromeleon software (Thermo Scientific) was used.

\section{${ }^{40} \mathrm{Ar}-{ }^{39} \mathrm{Ar}$ geochronology of biotite}

Biotite samples were separated from the bottom part of $\mathrm{C} 2$ from the Bílina and Libouš mines. For comparison, a biotite sample from the so-called greigite horizon of probably aeolian origin (Rojík, 2004) of the lower Miocene in the Sokolov Basin (the Jiř́i open cast mine) was prepared.

The biotites were prepared after coarse mechanic separation in the field followed by physical-chemical separation in the Czech Geological Survey laboratory. The separates were irradiated for 7 hours in the NM-304 package at the Oregon State University TRIGA reactor (CLOCIT position) along with the standard Fish Canyon tuff sanidine as a neutron flux monitor. The samples were analyzed in the New Mexico Geochronology Research Laboratory (NMGRL) in Socorro by a combination of bulk aliquot step-heating and single crystal laser fusion methods using a defocused diode laser to heat the samples.

\section{Specific weight}

5 whole-rock samples of C\# beds (weight 25-40g) were tested to determine approximate specific weight (density) in nature and dry stage. A simple method of weighing samples and measuring their displacement volume in a $200 \mathrm{ml}$ water cylinder were applied with approximately $5 \%$ precision in laboratory of the Severočeské doly a.s.

\section{RESULTS}

\section{Macroscopic description of individual C\# beds}

C1 is stratigraphically the lowest, and hence the oldest $\mathrm{C} \#$ bed. Because of its position in the oldest part of the lacustrine sequence, it is present in major part of the basin (Fig. 4A, B, D, F). C1 is less than $1 \mathrm{~cm}$ thick in the Bílina area (Fig. 4A), whereas in the Chomutov-Kadan̆ area (the Libouš Mine and its vicinity) its thickness is $6-12 \mathrm{~cm}$ (Fig. 4B, F). The $\mathrm{C} 1$ bed always contains laminae of fine biotite-quartz sand at its base. In contrast to the later $\mathrm{C} 2$ bed (described below), the biotite at the base of $\mathrm{C} 1$ is commonly strongly altered (sericitized) and could not hence be separated and further analyzed. The upper half of $\mathrm{C} 1$ in the Libouš Mine area is hard, while the lower parts of the bed in the Libouš Mine and the entire bed in other areas is rather soft. Convolute structures approximately in the middle part of the $\mathrm{C} 1$ bed (Figs. 4F; 5A) may be evidence of Kelvin-Helmholz and/or Rayleigh-Taylor instabilities
(Fernando, 1991; Gladstone et al., 2018), whereas the top third of the bed shows clear planar lamination (Fig. 4F).

C1A bed was discovered in the Libouš Mine as a discontinuous horizon with a maximum thickness of $0.5 \mathrm{~cm}$. It is located between the $\mathrm{C} 1$ and $\mathrm{C} 2$ beds near the bottom of K4 orbital-triggered minimum of potassium (or $\mathrm{K} / \mathrm{Al}$ ) concentrations. A similar discontinuous, up to $1 \mathrm{~mm}$ thick layer of anomalous $\mathrm{P}, \mathrm{Sr}$, and Ba contents occurs near the K4 minimum (according to the stratigraphic scheme in Matys Grygar et al., 2017) in the Bílina Mine. It could be a lateral equivalent of the $\mathrm{C} 1 \mathrm{~A}$ bed in the Libouš Mine. $\mathrm{C} 1 \mathrm{~A}$ has not been found in any heretofore studied drill core.

C2 bed (Fig. 3C) has the typical appearance of the C\# beds mainly in the central part of the basin. It also occurs in the Chomutov-Kadaň part of the basin, while further to the south and west the strata with $\mathrm{C} 2$ have not been preserved. The strata with C2 are also absent in the area near Krušné Hory Mountains (the ČSA open cast mine). The bed is 1.8$2.5 \mathrm{~cm}$ thick in most localities. At the base of $\mathrm{C} 2$, there is a $2 \mathrm{~mm}$ thick lamina of fine quartz-biotite sand (Fig. $4 \mathrm{G}$ ). In the vicinity of Teplice in the eastern part of the basin, this bed is up to $1 \mathrm{~cm}$ thick, and differs from typical $\mathrm{C} 2$ by a lack of biotite and quartz sand on the bottom. Biotite is macroscopically dark brown, reflective on cleavage planes, without any signs of alteration (Fig. 4G). The base of C2 bed in DU7 drill core is formed by fine rounded grains (clasts) of kaolinized rocks cemented by crandallite.

The bed C32' was first found in outcrop in the Libouš Mine but later was also identified during documentation of drill cores in the Bílina Mine area (LB433, LOM30, HK930). It is represented by a $0.5 \mathrm{~cm}$ thick, continuous crandallite-rich bed with less than $1 \mathrm{~mm}$ thick laminae of quartz-biotite sand at its base.

Similar bed C2" has until now only been found in two drill cores - LOM30 and LB433 - in the Bílina Mine area. The maximal thickness of this discontinuous orangecolored layer is $3 \mathrm{~mm}$. Biotite flakes at its base were not identified.

$\mathrm{C} 3$ is the youngest identified $\mathrm{CH}$ bed. Its similarity to C2 (the same thickness and shape) prevented the earlier distinguishing of $\mathrm{C} 2$ and $\mathrm{C} 3$ in the outcrops of the Bílina Mine. The C 3 thickness is $1.8-2.5 \mathrm{~cm}$. It differs from C2 only by a very thin or indistinct sandy lamina on its bottom, usually with biotite flakes not observed macroscopically due to their intensive weathering. As the $\mathrm{C} 3$ bed occurs in the topmost part of the Libkovice Member, its presence (preservation) is limited to the deepest part of the Most Basin between cities of Bílina, Litvínov, and Osek (Fig. 4C). Only a limited erosional remnant of $\mathrm{C} 3$ occurred several $\mathrm{m}$ from the surface within the deepest overburden profile of the Libouš Mine. 

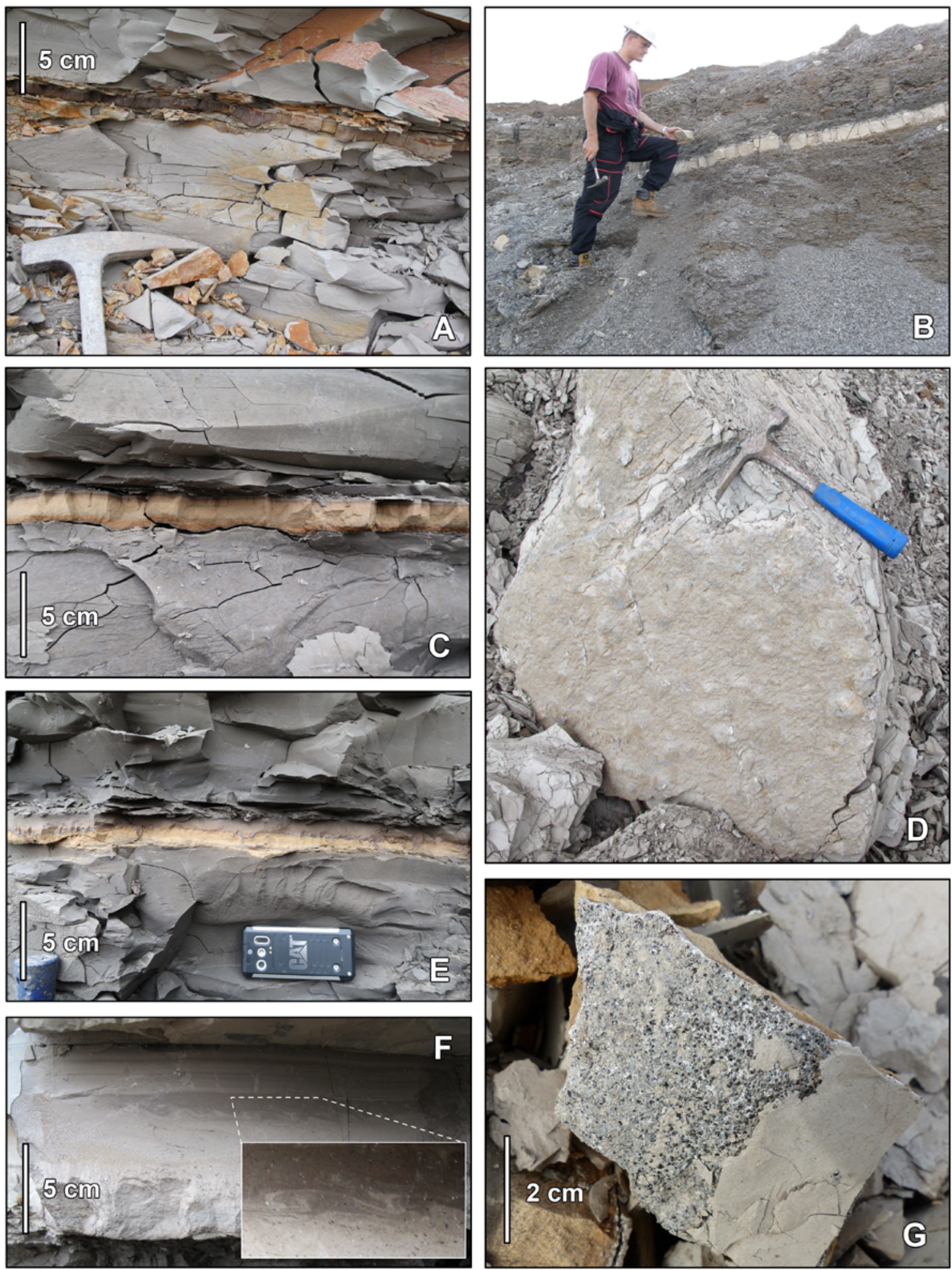

FIGURE 5. Macroscopic features of C\# beds: A) C1, Bílina Mine $1 \mathrm{~cm}$ thick, B) C1, Libouš Mine-maximal thickness of C\# beds within the basin, near to $12 \mathrm{~cm}, \mathrm{C}$ ) usual shape of $\mathrm{C} 2$, Bílina Mine, lower surface appears wavy due to frequent occurrence of circular depressions filled by bottom sandy laminae and phosphate, D) bottom surface of C1 Bilina Mine with typical flat relief frequently diversified by individual circular elevations 2-3cm in diameter $0.3-0.5 \mathrm{~cm}$ high, view from the bottom to the top, in fact these elevations represent filled depressions described in the previous figure, E) C3, Bílina Mine, F) C1, Libouš Mine detail of stratification with convolute bedding (see detail in window) in the middle sideritic part and lamination under the top of the bed, G) detail view to the bottom of C2, Bílina Mine with biotite oriented parallell to the bottom of bed and quartz sand grains. 
In all $\mathrm{C \#}$ beds, crandallite shows the microcrystalline character and gray or yellow to orange colors on their fresh cuts. These colors quickly turn white by weathering in outcrops. The C\# beds typically disintegrate to prisms via two systems of perpendicular cracks. The bottoms of the beds show irregular but very contrasting surfaces dividing the underlying clay and $\mathrm{C \#}$ bottom sand with many dents and mounds reflecting the original shape of the lake bottom (Fig. 4D). In some places it resembles circular bioturbation holes of Selenichnites, distinguished in sediments of the Holešice Member (Mikuláš et al., 2006). On the other hand, the upper contacts of the beds with clays are sharp and flat in all cases (Fig. 4A, C, E, F). The internal structure of the majority of $\mathrm{C \#}$ beds is similar and does not depend on the bed thickness. Substantial difference of $\mathrm{C} 1$ structure in the Libouš Mine is described above. In contrast to the situation in hosting Libkovice Member clays described above (LB433 borehole Fig. 3) no signs of bioturbation were found in any occurrence of $\mathrm{C} \#$ beds or its upper surface.

\section{Microscopic examination of $\mathrm{C} \#$ beds}

Both optical and electron microscopy confirmed the occurrence of distinct thin (1-3mm) sandy to silty laminae at the bottom of $\mathrm{CH}$ beds (Fig. 6A, B, C). In C3, the basal coarser lamina was not apparent macroscopically (Fig. 6C). Basal sandy to silty laminae consist of very fine-grained phosphate matrix with irregular to amoeboid crandallite grains. Individual idiomorphic biotite flakes (up to $0.5 \mathrm{~mm}$ in their largest dimension, Fig. 6D) and sharply limited irregular fragments of quartz $(0.1-0.5 \mathrm{~mm}$ in diameter, Fig. 6E, H, I) are embedded within this matrix. Flakes of green-brown biotite have commonly a perfectly euhedral shape of hexagonal plates (Fig. 6F) in some samples, with pronounced pleochroism (Fig. 6H, I). In some vertical cross-sections, the weathering of biotite crystals is obvious as the brush-shaped cleavage of their rims (Fig. 6D). In more weathered samples, e.g. C2 from the Libouš mine, the biotite crystals have lost their color and pleochroism. Present in every sample within the basal sandy laminae are apatite grains or crystals (Figs. 5; 6F) and irregular grains of some mineral completely transformed to a very fine mix of probably amorphous $\mathrm{SiO}_{2}$ and clay minerals. These are oval to angular grains with medium-high relief, often with inclusions of opaque minerals (Fig. 6F in the middle or 5D in the upper right part of the photo). Grain size of apatite and transformed minerals is similar to grain size of quartz. Apatite is also present as inclusions in biotite (Figs. 1 ; 6F). Several grains of a grass-green mineral with low relief without any cleavage were found; we interpret them as glauconite (Fig. 6E) but the small amount of material did not allow more accurate identification. Other common constituents of basal laminae are opaque (ore) minerals in globular concretions (up to $10 \mu \mathrm{m}$ in diameter Fig. 6F) or in the form of grains of various forms with similar dimensions (Fig. 6D, E) or they highlight the lower contact of the C\# bed with underlaying clay (Fig. 6A, B, C). High relief enhances visibility of a common minor admixture of irregularly dispersed fine idiomorphic crystals of 5-10 $\mu \mathrm{m}$ large siderite (Fig. 6H, F, G). Biotite and quartz represent up to $50 \mathrm{vol} . \%$ of the rock near the bottom of the bed, but its occurrence significantly decrease upwards (Fig. 6A, B). Their decrease correlates with the decreasing grain size. Although the admixture of quartz and biotite within the upper half of the $\mathrm{C \#}$ beds is not visible macroscopically, microscopy in many cases confirms their sparse presence. Their proportion in the upward direction decreases below the XRD detection limits. In all cases, the uneven, sharp contact with the underlying clays was confirmed (Fig. 6A, B, C, D). Biotite flakes near the contact are commonly oriented sub parallel to this contact or they lay just on it (Fig. 6D). Upward in the profile, this subparallel orientation of biotite flakes prevails but is not universal (Fig. 6I).

Clusters of crandallite precipitate highly variable in form (Figs. 1-9; 6F, G) or homogeneous orange mass (Fig. 6D) are the main constituent of every $\mathrm{C \#}$ bed. Individual grains can only be distinguished by SEM (Figs. 1-9; 6F), as their dimensions vary from 3 to $15 \mu \mathrm{m}$. A similar grain size is typical for idiomorphic crystals of carbonates, mostly siderite (Figs. 1-3; 6G; 7-9). Rare larger idiomorphic grains of carbonate were identified as dolomite by electron microprobe (Figs. 2; 6G; 7). Sparsely distributed flakes of biotite (partly sericitized) and irregular fragments of quartz and altered feldspar with a size of $20 \mu \mathrm{m}$ were identified. In the majority of samples, carbonate reaches up to $5 \mathrm{vol} . \%$. Only in the harder upper part of $\mathrm{C} 1$ from the Libouš Mine does its proportion exceed 50 vol.\% (Fig. 6G), i.e. the bed contains more carbonate than phosphate. In this part of $\mathrm{C} 1$ bed, the dimensions of all mineral grains are approximately $1 / 3$ or $1 / 2$ compared to the underlying phosphate-rich part of C\#. Syndepositional deformation convolute structures $1-2 \mathrm{~cm}$ thick in the lower half of siderite rich part of this bed (Fig. 6A) commented above represent a special feature of $\mathrm{C} 1$ of the Libouš Mine.

The upper boundary of $\mathrm{C \#}$ beds is in all cases flat with a very sharp transition to overlying clay. Mineral composition varies at the scale of several mineral grains (Fig. 6J). Phosphate — or mixed phosphate_ carbonate-bearing mass is upward replaced by clay with an admixture of carbonate and organic matter. Carbonate grains dispersed within clays are considerably coarser than the grains dispersed in the $\mathrm{C \#}$ bed (Fig. 6J). Clay minerals in the lacustrine clays are not distinguishable optically. Irregular dark fragments of very fine organic matter but often subangular silt-sized grains of quartz were usually found together with clay minerals and carbonates. Clays in the overburden and bellow $\mathrm{C \#}$ beds are intensively bioturbated (Planolites montanus according to 

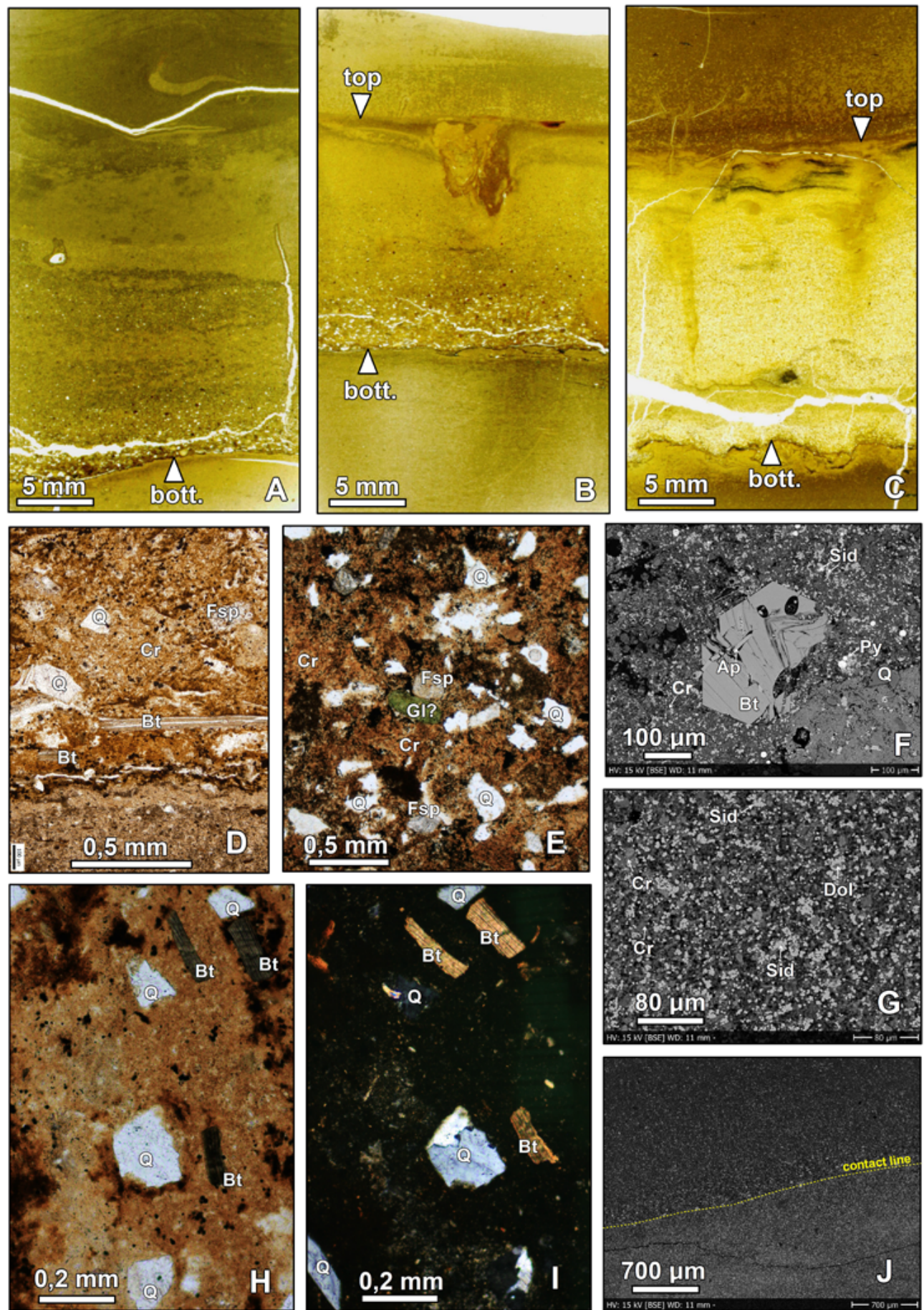

FIGURE 6. Microscopic features of C\# beds: A) C1, Libouš Mine, lower part with bottom (bott.) contact with clay , B) C1, Bílina Mine, total thickness in natural orientation with both bottom (bott.) and top contact, C) C3, Bílina Mine, total thickness in natural orientation with both bottom (bott.) and top contact, D) detail of the bottom contact of C1 Bílina Mine, vertical section, notice the large plates of biotite (Bt) and angular grains of quartz (Q) floating in basic orange crandallite matrix, probably altered feldspar (Fsp) is changed predominantly to mix of clay minerals, E) C1, CSA Mine, horizontal section through the sandy basal laminae, in the middle notice green grain of probably glauconite, white grains are represented by quartz, grainy gray, unidentified mineral grains (probably altered feldspar) completely transformed to the mix of clay minerals. F) C1, Libouš Mine, SEM detail of horizontal section of bottom sandy laminae. Bt: biotite, Sid: siderite (minute light gray grains), Q: quartz (angular gray grains), Cr: crandalite, grainy gray matrix, Py: pyrite framboids (white, circular shape), Ap: apatite, thin crystal penetrating plate of biotite, G) C1, Libouš Mine, SEM detail of the lower part of the bed, prevalence of gray matrix of crandallite $(\mathrm{Cr})$ and isometric grains of siderite (Sid), rare rhomboedric crystal of dolomite (Dol). H) C1, CSA Mine, vertical section of bottom sandy laminae with orange largely crandallite matrix, white angular quartz grains $(Q)$ and green-brown flat idiomorfic grains of biotite (Bt), Fsp: altered grains, probably former feldspar, Gl: glauconite, I) the same as $\mathrm{H}$ with analyzer (x Nicols), J) SEM detail of sharp upper contact (yellow line) of top sideritic C1 bed, Libouš Mine, with overlying silty clay. We can distinguish difference of both layers in granularity and content of light gray siderite. Top of crandallite bed has finer granularity and more siderite. Both features are changing in the profile during several grains. 


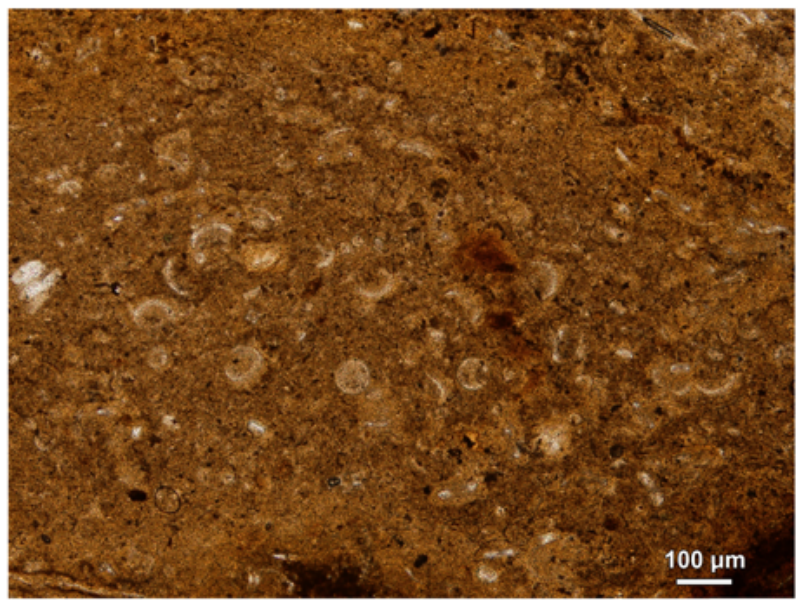

FIGURE 7. Biogenic circular structures in the $\mathrm{C} 3$ and $\mathrm{Cla}$ overburden clays. Dimensions of disordered circular to moon-like formed sections of individual objects reach $50-70 \mathrm{~mm}$ in diameter. Some of them are circular with thicker borders, some of them crescent up to box-like cross-sections depending of their orientation. Probably these are remains of some centric diatoms.

Mikuláš et al., 2006). It is very important that no traces of bioturbation were found in any of the $\mathrm{C \#}$ beds. Commonly, in the case of Bílina $\mathrm{C} 2$ and $\mathrm{C} 3$, wedge-like structures transect the beds from the top to the bottom (Figs. $5 \mathrm{C}$; $6 \mathrm{~B})$; however, no differences of mineral composition or structures are visible in these wedge areas. We interpret wedge-formed coloring as a product of weathering along diagenetic cracks, not an original sedimentary structure.

Microfossil-like structures were found only in two cases in the connection with $\mathrm{C \#}$ beds. In both cases, they are represented by flat circular objects probably composed of amorphous $\mathrm{SiO}_{2}$ (Fig. 6A, B), with their shapes resembling some circular diatoms. They were located in the $2 \mathrm{~mm}$ thick zone of an overburden of $\mathrm{C} 3$ bed in Bílina Mine and the vicinity of $\mathrm{C} 1 \mathrm{~A}$ bed in its Libouš Mine occurrence.

\section{Mineralogy by XRD}

XRD mineralogy of bulk samples is summarized in Table 1. Mineralogically the $\mathrm{C} 1$ crandallite bed occurs in two distinct forms. In the central part of the Most Basin, it is present as a $1 \mathrm{~cm}$ thick bed with prominent basal $1 \mathrm{~mm}$ thick fine-sand lamina with prevailing detrital quartz, biotite, kaolinite and a crandallite admixtures. Crandallite is dominant within the main part of $\mathrm{C} 1$; the admixtures of quartz, biotite and clay minerals (kaolinite, illite) were also found. The $\mathrm{C} 1$ bed from the western part of the basin near the Libouš Mine is thicker than in the central part of the basin; with siderite more abundant than crandallite in the upper half of $\mathrm{C \#}$ and crandallite more abundant than siderite in the soft, lower part of the bed. The main detectable admixture in siderite an crandallite is quartz. In the lower

TABLE 1. XRD mineralogy of C\# beds and its parts; *analyzed by CGS Prague, xxxx: dominant, xxx: abundant, xx: minor, $x$ : near detection limits. Names of individual samples represent code of C\# + locality (DNT: Libouš, DB: Bílina, CSA: Czechoslovak Army Mine) + sample of layer. A means the topmost sample in the profile

\begin{tabular}{|c|c|c|c|c|c|c|c|}
\hline sample & locality & description & 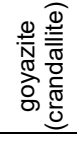 & $\begin{array}{l}\frac{N}{T} \\
\frac{T}{0}\end{array}$ & 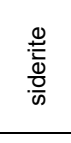 & 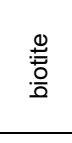 & 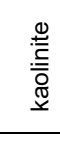 \\
\hline C2DNT & $\begin{array}{l}\text { Libouš North } \\
\text { Libouš }\end{array}$ & phosphate part & $x x x x$ & & & & $\mathrm{x}$ \\
\hline C1DNTA & $\begin{array}{l}\text { South } \\
\text { Libouš }\end{array}$ & phosphate-siderite hard part top & $x x x x$ & & $x x x x$ & & $\mathrm{x}$ \\
\hline C1DNTB & $\begin{array}{l}\text { South } \\
\text { Libouš }\end{array}$ & phosphate-siderite hard part & $x x x x$ & & $x x x x$ & & $\mathrm{x}$ \\
\hline C1DNTC & $\begin{array}{l}\text { South } \\
\text { Libouš }\end{array}$ & phosphate-siderite soft part & $x x x$ & $x x x$ & $x x x$ & & $x x$ \\
\hline C1DNTD & South & basal clastic lamina with phosphate & $x x x$ & $x x x x$ & $x x x$ & $x x$ & $x x$ \\
\hline C1DBA & Bílina Mine & phosphate part & $x x x x$ & $x x x$ & & & $x x$ \\
\hline C1DBB & Bílina Mine & basal clastic lamina with phosphate & $x x x x$ & $x x x x$ & & $x x x x$ & $x x$ \\
\hline C2DBA & Bílina Mine & phosphate part & $x x x x$ & $x$ & & $\mathrm{xx}$ & \\
\hline C2DBB & Bílina Mine & basal clastic lamina with phosphate & $x x x$ & $x x x x$ & & $x x x x$ & \\
\hline C3DBA & Bílina Mine & phosphate part & $x x x x$ & $x x$ & & $x x$ & $\mathrm{x}$ \\
\hline C3DBB & Bílina Mine & basal clastic lamina with phosphate & $x x x$ & $x$ & & $x x$ & $x$ \\
\hline C1ADNT & Libouš Mine & lenticular formation of phosphate & $x x x$ & $\mathrm{x}$ & & & $x$ \\
\hline C1CSAA & ČSA Mine & phosphate part & $x x x x$ & $x x x x$ & & $x x x$ & $x \mathrm{xx}$ \\
\hline C1CSAB & ČSA Mine & basal clastic lamina with phosphate & $x x$ & $x x x x$ & & $x x x x$ & $x x x$ \\
\hline C1DNTSD* & Libouš North & phosphate-siderite hard part & $x x x x$ & $\mathrm{x}$ & $x x x x$ & $x$ & \\
\hline C1DNTSE* & $\begin{array}{l}\text { Libouš North } \\
\text { Libouš }\end{array}$ & basal clastic lamina with phosphate & $x x x$ & $x x$ & $x x x$ & & $\mathrm{x}$ \\
\hline C1DNTJC* & $\begin{array}{l}\text { South } \\
\text { Libouš }\end{array}$ & phosphate-siderite soft part & $x x x x$ & $\mathrm{x}$ & $x x x x$ & & \\
\hline C1DNTJD* & South & basal clastic lamina with phosphate & $x x x x$ & & $x x x$ & $\mathrm{x}$ & \\
\hline
\end{tabular}


third of $\mathrm{C} 1$, the diffraction lines of clay minerals (kaolinite, illite, especially illite-smectite) are more intensive than those of siderite and crandallite. The composition of the $5 \mathrm{~mm}$ thick bottom sandy lamina is similar as in the central part of the basin (Bílina Mine, ČSA Mine areas). Biotite, quartz, and crandallite are dominant minerals, siderite and clay minerals are detectable, and trace amounts of pyrite were also found. The content of illite-smectite is higher and could indicate weathering of biotite or feldspar.

$\mathrm{C} 2$ bed is laterally very homogeneous throughout the whole area of its occurrence. Basal sandy laminae are distinct mainly in non-weathered outcrops of the Bílina Mine (Fig. 4G); their composition is dominated by biotite with significant admixtures of crandallite and quartz and a minor amount of kaolinite. A major component of the soft, main part of $\mathrm{C} 2$ bed is crandallite, minor admixtures are kaolinite and some amorphous matter, probably opal, minor amounts of biotite were also detected in the Bílina Mine. Because of intensive weathering of $\mathrm{C} 2$ on the Libouš Mine outcrops, the sandy lamina on the bottom was not macroscopically distinguishable and thus were not subjected to XRD analysis.

The youngest bed C3, preserved mainly in the deepest central part of the basin and little erosional remnant in western part, shows mineralogy very similar to $\mathrm{C} 2$. C3 consists mainly of crandallite with an admixture of biotite and traces of clay minerals.

The lenticular C1A bed in the Libouš Mine resembles $\mathrm{C} 2$ in composition, exclusively crandallite with some admixture of amorphous matter (probably opal). Other C\# beds were not analyzed because of the insufficient amount of representative material.

Generally, XRD analyses confirm the above-described strong mineralogical difference between bottom sandy laminae with prevalence of detrital biotite and quartz and main bed body formed predominantly by phosphate or siderite only with some admixture of other minerals.

\section{Chemical composition}

The presence of crandallite-group phosphates is indicated by high contents of $\mathrm{P}_{2} \mathrm{O}_{5}, \mathrm{CaO}, \mathrm{Sr}$ and $\mathrm{Ba}$. Minimal $\mathrm{P}_{2} \mathrm{O}_{5}$ content in $\mathrm{C \#}$ samples slightly exceeds $6 \mathrm{wt} . \%$, maximum reaches $22 \mathrm{wt} . \%$ (Table 2). The content of phosphate mineral calculated from $\mathrm{P}_{2} \mathrm{O}_{5}$ content is equivalent to entire content of $\mathrm{SrO}, \mathrm{BaO}, \mathrm{CaO}$ and the stoichiometric part of $\mathrm{Al}_{2} \mathrm{O}_{3}$. In such case, the content of crandallite in samples gives 18-69wt.\% in samples within the C\# bed. The content of crandallite is generally lowest in $\mathrm{C} 1$ in the Libouš Mine and basal parts of other C\# occurrences. In the first case, it is due to the high content of siderite. In the other cases crandallite is diluted by clastic biotite, quartz and other minerals. On the contrary, the highest phosphate contents were detected in the soft parts of the $\mathrm{C \#}$ beds above the basal sandy laminae. Samples of the harder, upper half of $\mathrm{C} 1$ from the Libous Mine show a significant excess of $\mathrm{FeO}$ and $\mathrm{MgO}$ over $\mathrm{CaO}$ in the residue after crandallite subtraction from the entire composition. The high content of $\mathrm{CO}_{2}$ in these samples corresponds with that fact, so it can be concluded that $\mathrm{MgO}$ and $\mathrm{FeO}$ are bound in carbonates, mainly siderite identified according to XRD. In the soft lower part, the $\mathrm{P}_{2} \mathrm{O}_{5}$ content is lower than in other samples of $\mathrm{CH}$ beds what is compensated by higher $\mathrm{SiO}_{2}$ and $\mathrm{Al}_{2} \mathrm{O}_{3}$ content. This observation agrees with XRD results giving a prevalence of clay minerals over phosphates or carbonates. In C2 and C3 a slight excess of $\mathrm{Ba}$ over $\mathrm{Sr}$ was found. On the contrary, $\mathrm{C} 1$ shows more $\mathrm{Sr}$ than $\mathrm{Ba}$. Excess of $\mathrm{Al}_{2} \mathrm{O}_{3}$ over the crandallite content is
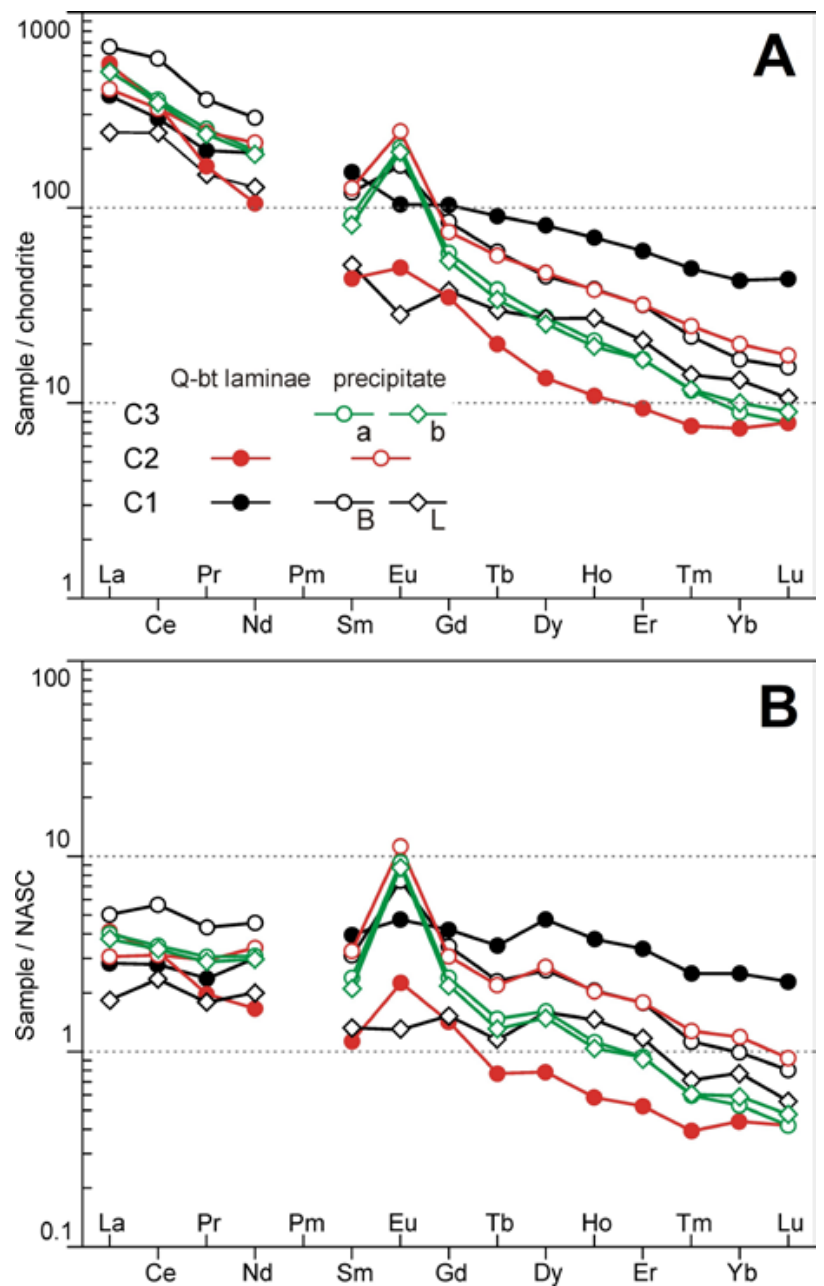

FIGURE 8. Cr REE-REE patterns of crandallite beds normalized to: A) chondrite (Boynton, 1984) and B) North American Shale Composite (NASC: Haskin and Haskin, 1966). Samples: C3, represent two samples of phosphate bed divided to two ones, locality Bílina, A) upper half of profile, B) lower half of profile; C2, sample of bottom sandy laminae + sample of the whole phosphate precipitate part, both Bílina locality; C1, sample of bottom sandy laminae of Bílina locality + sample of Bílina (B) and Libouš (L) phosphate precipitate part of bed. 
TABLE 2. Chemical composition of $\mathrm{C \#}$ beds and its parts. For sample identification see explanations of the Table 1

\begin{tabular}{|c|c|c|c|c|c|c|c|c|c|c|c|c|c|c|}
\hline \multirow{3}{*}{ sample } & $\mathrm{SiO}_{2}$ & $\mathrm{TiO}_{2}$ & $\mathrm{Al}_{2} \mathrm{O}_{3}$ & $\mathrm{Fe}_{2} \mathrm{O}_{3}$ & $\mathrm{FeO}$ & $\mathrm{MgO}$ & $\mathrm{MnO}$ & $\mathrm{CaO}$ & $\mathrm{SrO}$ & $\mathrm{BaO}$ & $\mathrm{Li}_{2} \mathrm{O}$ & $\mathrm{Na}_{2} \mathrm{O}$ & $\mathrm{K}_{2} \mathrm{O}$ & $\mathrm{P}_{2} \mathrm{O}_{5}$ \\
\hline & WET & WET & WET & WET & WET & WET & WET & WET & WET & WET & WET & WET & WET & WET \\
\hline & $\%$ & $\%$ & $\%$ & $\%$ & $\%$ & $\%$ & $\%$ & $\%$ & $\%$ & $\%$ & $\%$ & $\%$ & $\%$ & $\%$ \\
\hline C1DNTA & 12,91 & 0,21 & 12,59 & 0,73 & 28,25 & 1,94 & 0,456 & 3,46 & 0,570 & 1,704 & 0,008 & 0,12 & 0,66 & 7,181 \\
\hline C1DNTB & 13,31 & 0,20 & 10,40 & 0,19 & 27,30 & 1,79 & 0,499 & 3,59 & 0,596 & 1,771 & 0,006 & 0,13 & 0,45 & 7,694 \\
\hline C1DNTC & 27,68 & 0,22 & 20,25 & 0,95 & 13,05 & 1,56 & 0,353 & 3,48 & 0,589 & 0,907 & 0,005 & 0,23 & 0,15 & 7,809 \\
\hline C1DNTD & 34,83 & 0,24 & 18,71 & 3,16 & 9,22 & 1,37 & 0,315 & 3,11 & 0,348 & 0,033 & 0,005 & 0,29 & 0,86 & 6,155 \\
\hline C1DBA & 23,25 & 0,03 & 21,88 & 2,75 & 1,42 & 0,27 & 0,159 & 9,53 & 1,424 & 0,073 & 0,003 & 0,12 & 0,64 & 15,346 \\
\hline C1DBB & 21,25 & 0,34 & 21,37 & 3,12 & 2,15 & 0,45 & 0,183 & 8,13 & 1,290 & 0,083 & 0,004 & 0,14 & 1,16 & 14,523 \\
\hline C2DNT & 9,05 & 0,17 & 27,12 & $<0.01$ & 0,52 & 0,12 & 0,045 & 9,53 & 1,761 & 3,871 & 0,003 & 0,10 & 0,24 & 20,859 \\
\hline C2DBA & 5,83 & 0,25 & 27,96 & 0,67 & 0,60 & 0,17 & 0,025 & 12,06 & 2,074 & 3,315 & 0,003 & 0,10 & 0,35 & 22,511 \\
\hline C2DBB & 23,84 & 0,60 & 27,17 & 1,70 & 1,74 & 0,75 & 0,042 & 4,12 & 1,375 & 0,913 & 0,014 & 0,16 & 1,54 & 13,156 \\
\hline C3DB & 6,39 & 0,51 & 27,51 & 0,60 & 1,13 & 0,18 & 0,028 & 13,18 & 1,515 & 2,965 & 0,003 & 0,16 & 0,40 & 22,043 \\
\hline C1DBA (Cr01c) & 24,65 & 0,26 & 20,79 & 1,68 & 1,62 & 0,47 & 0,071 & 5,99 & 1,564 & 3,293 & 0,002 & 0,21 & 0,55 & 14,969 \\
\hline C1DBB (Cr01t) & 41,90 & 0,56 & 18,35 & 1,77 & 1,72 & 0,96 & 0,046 & 9,77 & 0,274 & 0,510 & 0,009 & 0,23 & 1,17 & 8,692 \\
\hline $\mathrm{C} 2 \mathrm{DBA}(\mathrm{CrO2c})$ & 7,52 & 0,26 & 27,41 & 0,18 & 1,01 & 0,26 & 0,015 & 6,94 & 1,850 & 5,655 & 0,001 & 0,10 & 0,34 & 22,599 \\
\hline C2DBB (Cr02t) & 47,66 & 0,64 & 25,95 & 1,96 & 2,30 & 1,28 & 0,033 & 1,20 & 0,369 & 0,876 & 0,017 & 0,18 & 1,35 & 3,278 \\
\hline C3DB (Cr03a) & 6,57 & 0,22 & 26,68 & 1,48 & 0,92 & 0,28 & 0,028 & 6,60 & 1,631 & 4,772 & 0,001 & 0,19 & 0,41 & 22,641 \\
\hline C3DB (CrO3b) & 16,53 & 0,29 & 24,59 & 0,54 & 0,95 & 0,42 & 0,026 & 5,73 & 1,768 & 4,972 & 0,002 & 0,25 & 0,71 & 19,092 \\
\hline
\end{tabular}

probably bound in micas, kaolinite, or other clay minerals. Higher content of $\mathrm{SiO}_{2}$ in the main crandallite parts of some samples confirms probable content of opal, which could be the XRD amorphous phase. $\mathrm{SiO}_{2}$ in the form of opal were often identified together with other minerals by electron microprobe (Table I; Figs I-IX) as inseparable ingrowths with crandallite clusters.

In some samples ca. $1 \mathrm{wt} \% \mathrm{~S}$ was found, however neither sulfate nor sulfidic phase was detected by XRD. This could mean the presence of $\mathrm{SO}_{4}{ }^{2+}$ in the crandallite (partial $\mathrm{PO}_{4}{ }^{3-}$ replacement by $\mathrm{SO}_{4}^{2-;}$ Dill, 2001). Alternatively, the sulfide micro-concretions visible by optic and SEM microscopy could have been present in abundances below the XRD detection limit.

Carbon not bound in carbonates (mainly organic) does not exceed $4 \mathrm{wt} . \%$. Fewer concentrations of non-carbonate $\mathrm{C}$ were detected in $\mathrm{C} 1$ bed of Libouš Mine where the content of carbonates is maximal.

REE content was determined in 7 samples of C\# beds prevalently from the Bílina Mine area. One sample represents part of $\mathrm{C} 1$ of Libouš locality. Results are summarized in Table 3 and presented also in graphic form (Fig. 8). Data normalized to chondrite (Fig. 8A; Boynton,
1984) and North American Shale Composite (Fig. 8B; NASC: Haskin and Haskin, 1966) show a significant positive Eu-anomaly in C\# samples from the Bílina Mine except for quartz-biotite laminae. Only the sample of $\mathrm{C} 1$ from the Libouš Mine shows a slight negative Eu-anomaly.

\section{Strontium ${ }^{87} \mathrm{Sr} /{ }^{86} \mathrm{Sr}$ isotope systematics}

All results of strontium isotopic analyses are presented in Table II and Figure 9. Strontium isotope ratios were analyzed in C1, C2 and C3 from the Bílina Mine. Basal sandy laminae and main crandallite parts of beds were separated and analyzed in the case of $\mathrm{C} 1$ and $\mathrm{C} 2$, whereas C3 was only split to lower and upper halves. The initial ${ }^{87} \mathrm{Sr} /{ }^{86} \mathrm{Sr}$, recalculated to $17 \mathrm{Ma}$, vary from 0.70974 to $0.71022 \mathrm{ppm}$ and display only subtle variations (Table II; Fig. 9). The same Sr isotope ratios were found in basal sandy layers and upper massive parts of C3. Negligible variations in ${ }^{87} \mathrm{Sr} /{ }^{86} \mathrm{Sr}$ isotope ratios, in addition, do not reflect the relatively wide variations in $\mathrm{Sr}$ contents (2300-15700ppm). Similar isotope ratios $\left({ }^{87} \mathrm{Sr} /{ }^{86} \mathrm{Sr}_{17}=0.70859-0.70992\right)$ were also obtained for phosphate concretions in the Holešice Member (the main coal seam) from the Libouš Mine.

On the other hand, strontium isotope ratios in the Most Basin clays display unusual variability ranging from 0.7122

TABLE 3. REE composition of $\mathrm{C \#}$ beds and its parts. For sample identification see explanations of the Table 1

\begin{tabular}{|c|c|c|c|c|c|c|c|c|c|c|c|c|c|c|c|c|c|}
\hline sample & La & $\mathrm{Ce}$ & $\mathrm{Pr}$ & $\mathrm{Nd}$ & $\mathrm{Sm}$ & $\mathrm{Eu}$ & $\mathrm{Gd}$ & $\mathrm{Tb}$ & Dy & Ho & $\mathrm{Er}$ & $\mathrm{Tm}$ & $\mathrm{Yb}$ & $\mathrm{Lu}$ & Sum_REE & $\mathrm{Eu} / \mathrm{Eu}^{*}$ & $\mathrm{Ce} / \mathrm{Ce}^{*}$ \\
\hline C1DBA (Cr01c) & 206,20 & 468,45 & 43,68 & 173,21 & 23,33 & 12,08 & 21,94 & 2,82 & 14,33 & 2,75 & 6,65 & 0,71 & 3,50 & 0,49 & 980,13 & 1,63 & 1,19 \\
\hline C1DBB (Cr01t) & 116,14 & 231,26 & 23,90 & 114,12 & 29,64 & 7,64 & 26,72 & 4,29 & 26,11 & 5,04 & 12,60 & 1,58 & 8,85 & 1,39 & 609,28 & 0,83 & 1,06 \\
\hline C3DBA (Cr03a) & 164,63 & 288,90 & 30,86 & 117,32 & 17,91 & 14,98 & 15,17 & 1,81 & 8,85 & 1,50 & 3,52 & 0,38 & 1,87 & 0,25 & 667,96 & 2,78 & 0,98 \\
\hline C3DBB (Cr03b) & 154,71 & 277,38 & 29,03 & 112,72 & 15,90 & 14,18 & 13,84 & 1,60 & 8,19 & 1,39 & 3,50 & 0,38 & 2,09 & 0,29 & 635,20 & 2,92 & 1,00 \\
\hline C2DBB (CrO2t) & 169,01 & 268,74 & 19,88 & 63,09 & 8,46 & 3,62 & 9,01 & 0,95 & 4,32 & 0,78 & 1,97 & 0,25 & 1,55 & 0,25 & 551,88 & 1,27 & 1,12 \\
\hline C2DBA (Cr02c) & 125,54 & 259,20 & 29,66 & 129,15 & 24,56 & 18,09 & 19,48 & 2,69 & 14,95 & 2,72 & 6,69 & 0,80 & 4,19 & 0,56 & 638,29 & 2,53 & 1,02 \\
\hline C1DNT (DH1232AFOSF) & 75,24 & 195,20 & 18,03 & 76,17 & 9,92 & 2.08 & 9,70 & 1,41 & 8,73 & 1,95 & 4,38 & 0,45 & 2,74 & 0,34 & 406,34 & 0,65 & 1,28 \\
\hline
\end{tabular}




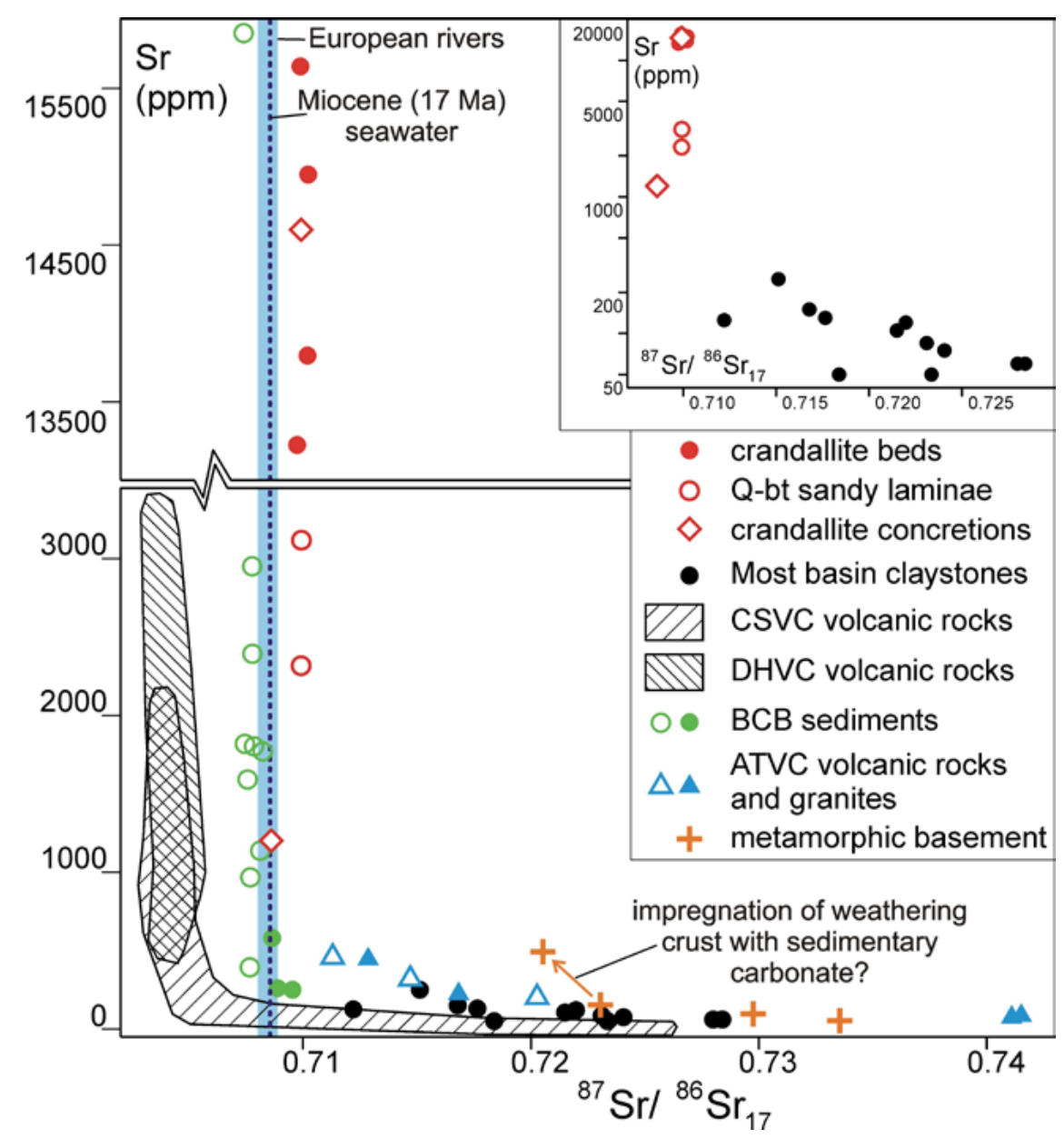

FIGURE 9. Strontium isotope diagram of Miocene sediments and potential sources (data see Table I). Text abbreviations, CSVC: České Středohoří Volcanic Complex, DHVC: Doupovské.

to $0.7284 \mathrm{ppm}$ at low but relatively constant $\mathrm{Sr}$ contents (50-250ppm). The strontium signature of clays resembles values obtained from metamorphic basement and magmatic rocks of the Altenberg-Teplice Volcanic Complex (ATVC). The gneisses are characterized by ${ }^{87} \mathrm{Sr} /{ }^{86} \mathrm{Sr}_{17}$ ratios $0.72307-$ 0.78992 at rather low $\mathrm{Sr}$ contents (40-150ppm), with an exception of the sample from the buried weathering surface sampled in Merkur locality in the western margin of the Most Basin. This sample has elevated $\mathrm{Sr}$ content reaching 500ppm with ${ }^{87} \mathrm{Sr} /{ }^{86} \mathrm{Sr}_{17}$ shifted to more pristine value 0.72052 , suggesting possible influx of non-radiogenic strontium by surface water (possibly from nearby volcanic rocks of the Doupovské Hory Mts.) prior to burial of the weathering surface by Miocene sediments.

Broader variability of $\mathrm{Sr}$ content and isotope composition was found within the late- to post-Variscan Altenberg-Teplice Volcanic Complex. The rocks of the early phase of that volcanic complex (including Fláje granite and Schönfeld-Altenbeg sequence) have higher $\mathrm{Sr}$ contents (69-450ppm) with only weakly radiogenic signature $\left({ }^{87} \mathrm{Sr} /{ }^{86} \mathrm{Sr}_{17}=0.71123-0.7202\right.$ : Walther et al., 2016 and new data for Fláje granite). The younger volcanic and dike rocks of that volcanic complex have very low $\mathrm{Sr}$ contents (9-90ppm) and elevated Rb concentrations (150$470 \mathrm{ppm}$ ), that resulted in highly radiogenic $\mathrm{Sr}$ signatures $\left({ }^{87} \mathrm{Sr} /{ }^{86} \mathrm{Sr}_{17}=0.73909-1.73909\right.$. The consequence of the deficiency of $\mathrm{Sr}$ relative to $\mathrm{Rb}$ is extremely pronounced in the latest magmatic products of the complex, represented by $\mathrm{Sn}$-microgranites $(\mathrm{Sr}=3-6 \mathrm{ppm}, \mathrm{Rb}=1000-1200 \mathrm{ppm}$; Stemprok, 2016): here the values of ${ }^{87} \mathrm{Sr}^{86} \mathrm{Sr}_{17}$ exceed 1.9 and reach maximum of 3.5 .

For comparison, we also present isotopic and concentration data for $\mathrm{Sr}$ in the Oligocene to lower Miocene alkaline volcanic complexes of the České Středohoří Volcanic Complex (CSVC) Mts. and the Doupovské Hory Volcanic Complex Mts., were considered possible resources for crandallite beds and the Most Basin clays. A relatively narrow range in ${ }^{87} \mathrm{Sr} /{ }^{86} \mathrm{Sr}_{17}$ ratios (0.70359-0.70495) of the Doupovské Hory volcanic complex encompasses primitive as well as 
highly fractionated rocks with highly variable Sr contents (520-3350ppm, Holub et al., 2010; Rapprich and Holub, 2008). Most of th<<e volcanic rocks within the CSVC isotopically resemble those of DHVC. $\left({ }^{87} \mathrm{Sr} /{ }^{86} \mathrm{Sr}_{17}=\right.$ 0.703155- 0.70513; Sr= 70-1700ppm: Ackerman et al., 2015; Ulrych et al., 2002), but several strongly fractionated phonolites with $\mathrm{Sr}$ contents decreased to $11-133 \mathrm{ppm}$ revealed significantly modified ratios (up to 0.72581 , Ackerman et al., 2015) reaching the values of the metamorphic basement. The phonolites with the most radiogenic signatures differ from gneisses in even lower $\mathrm{Sr}$ contents (11-13ppm). The phonolite domes and exposed laccoliths also represent relatively small bodies, not providing enough sedimentary material to significantly modify the geochemical signatures of sediments in the Most Basin.

\section{$\mathrm{O}$ and $\mathrm{C}$ stable isotope composition of siderite}

Because mineralogical analysis and optical and SEM microscopy detected a higher content of siderite mainly in $\mathrm{C} 1$ in the Libous Mine, stable isotope $\mathrm{C}$ and $\mathrm{O}$ analyses were performed to estimate under what conditions carbonate precipitated in this bed. The $\mathrm{C}$ and $\mathrm{O}$ stable isotope ratios plot to a single line in the scatterplot for all analyzed samples (Fig. 10), with $\delta^{13} \mathrm{C}$ ranging from 1.1 to -3.2 and $\delta^{18} \mathrm{O} \%$ from -4.5 to $-6.0 \%$ vs. Pee Dee Belemnite (PDB) (Table III).

\section{Organic geochemistry}

No substantial differences in the micropetrography and organic geochemistry in the clay sediment below and above C\# beds was found by Havelcová et al. (2015). However, that previous study (Havelcová et al., 2015) did not include directly the $\mathrm{C \#}$ beds. The organic compounds in $\mathrm{C \#}$ beds (B samples) and in overlying (A samples) and underlying clays ( $\mathrm{C}$ samples) are characterized in Table IV. The organic analysis showed features indicating the biogenic origin of organic compounds in sediment, but it also revealed significant differences in parameters documenting specific conditions during the $\mathrm{C \#}$ bed formation. Parameters that are similar for all sample extracts include the Carbon Preference Index (CPI) or the distribution of $n$-alkanes. The CPI ranges from 2.4 to 4.0 , which is typical for land-plant input and in the distribution of $n$-alkanes only a very slight predominance of shortchain $n$-alkanes (up to 20) in C \# beds are documented. The parameter TAR (Terrigenous/Aquatic Ratio) is one of the results indicating a difference in the conditions of $\mathrm{C \#}$ beds formation in comparison with overlying and underlying clays (Fig. 11A). The lower TAR values for extracts from $\mathrm{C \#}$ beds suggests a reduced supply in the proportion of substances derived from terrestrial plants in relation to materials of aquatic ecosystems (Bourbonniere and Meyers, 1996). The $\mathrm{Pr} / \mathrm{Ph}$ ratio of isoprenoid hydrocarbons of pristane $(\mathrm{Pr})$ and phytane $(\mathrm{Ph})$, which are

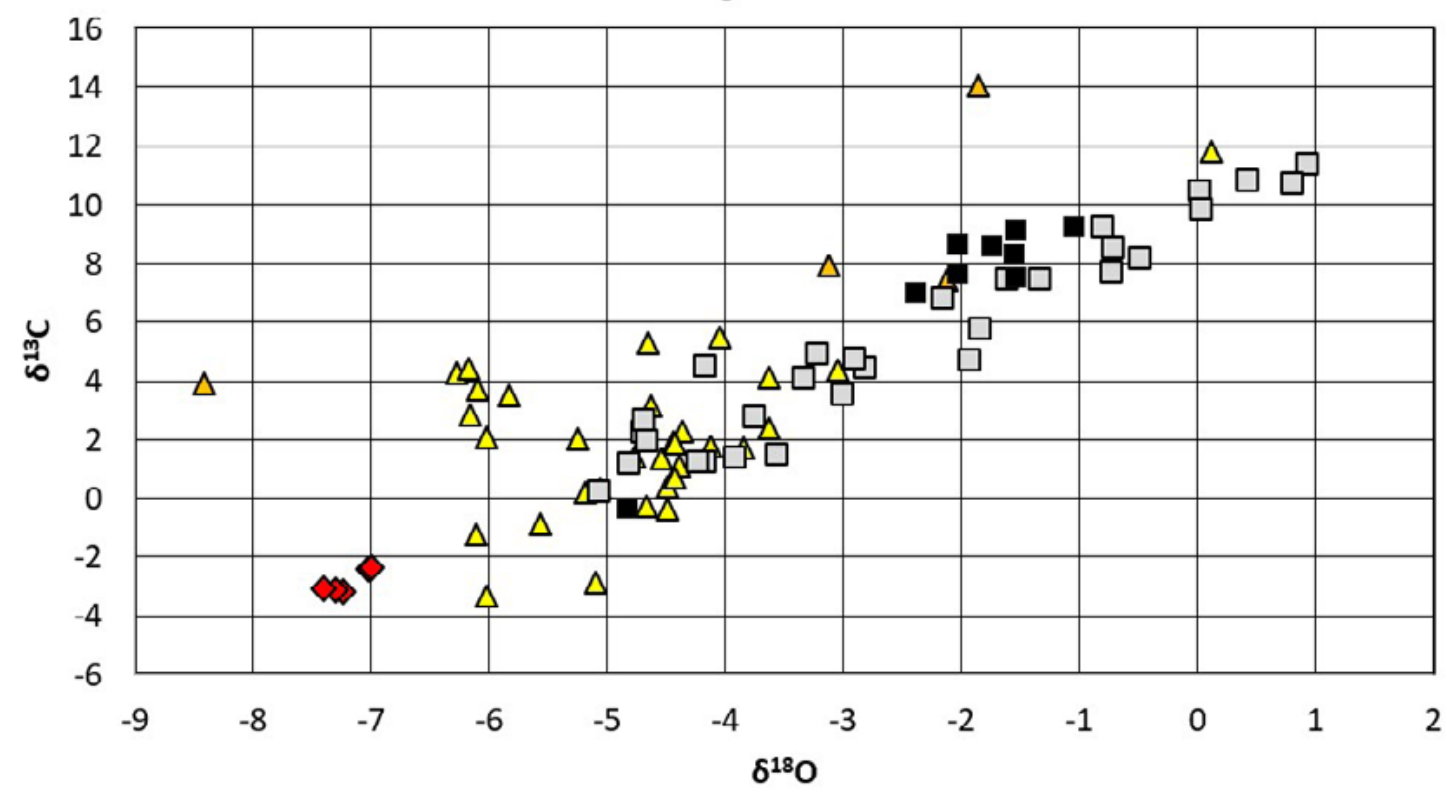

\section{$\triangle$ Holešice Member SP257 $\triangle$ Holešice Member}

$\square$ Libkovice Member

- Libkovice Member SP257 $\diamond$ C1 bed Libouš siderite

FIGURE 10. Composition of $\mathrm{C}$ and $\mathrm{O}$ stable isotopes of Libkovice Member carbonates according to its stratigraphic relations. Samples of clays from SP257, LB297, AL405, HK521 drill holes core. SP257 samples are detached because it belongs to the Libouš locality, the source of the C1 siderite sample. 
diagenetic products of phytol (chlorophyll) is reduced in the case of $\mathrm{C \#}$ beds compared to the surrounding clays (Fig. 11B). This ratio characterizes the redox conditions in situ in processes of microbial degradation of organic matter (Didyk et al., 1978). Other ratios that differ for $\mathrm{C \#}$ beds are $\mathrm{Pr} / n-\mathrm{C}_{17}$ (Fig. $11 \mathrm{C}$ ) and $\mathrm{Ph} / n-\mathrm{C}_{18}$ (Fig. 11D). These ratios are based on the greater resistance of isoprenoid hydrocarbons to microbial degradation compared to $n$-alkanes and are mainly used to determine the maturity and biodegradation of the material (ten Haven et al., 1987). Using derivatized extracts, significant differences were found between $\mathrm{CH}$ beds and surrounding clays for fatty acids (Fig. 11E). Extracts from C\# beds extracts contain a higher proportion of Fatty Acids (FA) with shorter carbon chains and used $\mathrm{FA}$ ratio $\left(\mathrm{FA}_{20-28} /\right.$ $\mathrm{FA}_{12-18}$ ) documents the proportion of fatty acids derived from vegetable waxes (longer chains) and bacterial - algal origin (shorter chains) (Volkman et al., 1980).

\section{${ }^{40} \mathrm{Ar} /{ }^{39} \mathrm{Ar}$ age and chemical composition of biotite}

Biotite from $\mathrm{C} 2$ bed in the Bílina and Libouš mines produced ages of $17.37 \pm 0.04 \mathrm{Ma}$ and $17.63 \pm 0.02 \mathrm{Ma}$, respectively. Both these ages are older than 17.07Ma, which was inferred for the $\mathrm{C} 2$ age obtained by the combination of paleomagnetic analysis and geochemical cyclostratigraphy for drill core MR93 and other long cores studied in detail (Matys Grygar et al., 2017, 2019b, 2021). Both C2 biotite samples have very similar compositions (Table 4). This supports the idea of their unique magmatic source.

The chemical composition of biotite from both localities in the Most Basin differs from the composition of the biotite sample collected from the so-called "greigite horizon" (Rojík, 2004) in the Sokolov Basin (western part of the Ohře Rift). C2 bed biotite in the Most Basin has higher contents of $\mathrm{Ti}, \mathrm{Mg}$ and $\mathrm{Fe}$, whereas the Sokolov Basin biotite is enriched in $\mathrm{Al}$ and $\mathrm{K}$. The biotite from the Sokolov Basin provided Carboniferous age (322.7 $\pm 0.2 \mathrm{Ma})$ corresponding well to the magmatic age of the NejdekEibenstock granite pluton $\left({ }^{207} \mathrm{~Pb} /{ }^{206} \mathrm{~Pb}\right.$ age of $320 \pm 8 \mathrm{Ma}$ : Kempe et al., 2004).

\section{Specific weight (density)}

The whole-rock samples of $\mathrm{C \#}$ beds from the Bílina and Libouš mines have a very low specific weight (density) around $1.02 \mathrm{~g} / \mathrm{cm}^{3}$ in dry state and $1.26 \mathrm{~g} / \mathrm{cm}^{3}$ in natural state. In comparison with the known density of crandallite $\left(2.8-3 \mathrm{~g} / \mathrm{cm}^{3}\right)$, the low density of $\mathrm{C \#}$ indicates that the most concentrated phosphate layers have very high porosity of $60-66 \%$. Only in the case of the siderite-bearing upper part of $\mathrm{C} 1$ from the Libouš Mine the density in a dry stage was higher: 1.16 to $1.31 \mathrm{~g} / \mathrm{cm}^{3}$, which could mean that the pores in $\mathrm{C} 1$ were partly filled by siderite.
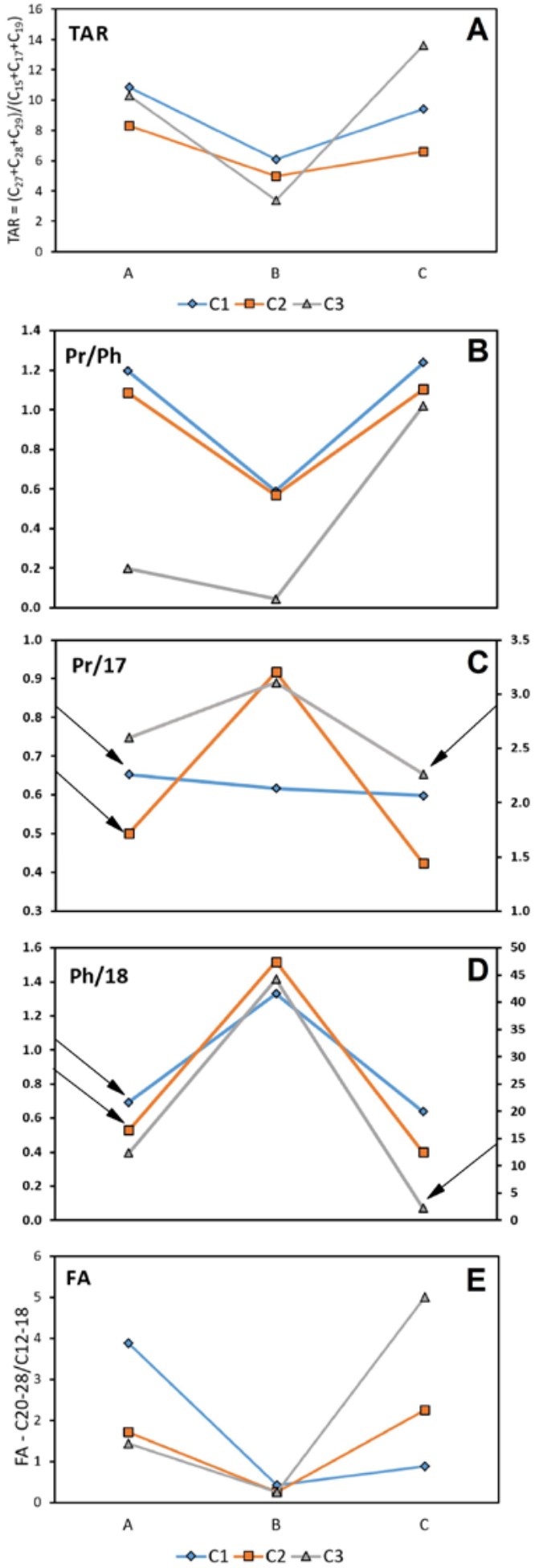

FIGURE 11. Relations of extractable organic compounds of $\mathrm{C} \#$ beds and surrounding clays (see Table II). A) overburden clay, B) phosphate layer, $\mathrm{C}$ ) underlying clay. $\mathrm{Pr} / \mathrm{Ph}$, pristane $(\mathrm{Pr})$ and phytane $(\mathrm{Ph})$ ratio, FA: Fatty Acids ratio $\left(\mathrm{FA}_{20-28} / \mathrm{FA}_{12-18}\right)$, ratio of long chain fatty acids $\left(\mathrm{C}_{12}-\mathrm{C}_{18}\right)$ and short chain fatty acids $\left(\mathrm{C}_{20}-\mathrm{C}_{28}\right)$, TAR: Terrigenous/ Aquatic Ratio, ratio of certain $n$-alkanes: TAR $=\left(n-\mathrm{C}_{27+29+31}\right) /(n$ $\mathrm{C}_{15+17+19}$ ), CPI: Carbon Preference Index, relative abundance of odd vs. even carbon-numbered $n$-alkanes: $\mathrm{CPI}=1 / 2\left(n-\mathrm{C}_{25+27+29+31+33} / n\right.$ $\left.\mathrm{C}_{24+26+28+30+32}+n-\mathrm{C}_{25+27+29+31+33} / n-\mathrm{C}_{26+28+30+32+34}\right)$. 


\section{DISCUSSION}

We assign the $\mathrm{C \#}$ beds within the lacustrine clays of the Libkovice Member to combination of the deposition of clastic components with organic matter and extensive formation of authigenic components. The clastic components were transported to the basin in the same manner as "normal" lacustrine clays below and above the $\mathrm{C \#}$ beds. The authigenic compounds were precipitated near the bottom or under the surface of bottom of the lake from solutions, or by transformation of some extraordinary material. Our observations show that the clastic portion of the $\mathrm{C \#}$ beds comprises biotite and quartz grains of sand- to silt grain size. Clay minerals identified by XRD can be detritic as in the entire Libkovice Member, or they could result from alteration of mineral grains like feldspars and micas. Carbonates, sulfides, amorphous silica and phosphates found in the $\mathrm{C \#}$ beds were likely precipitated near the bottom of the lake.

\section{Origin of biotite-quartz horizons in $\mathrm{C} \#$ beds}

Clastic material is found at the base of each $\mathrm{C \#}$ bed. Novák et al. (1993) interpreted the biotite flakes abundant in the $\mathrm{C \#}$ bases as a sign of their volcanic origin. Dating, however, showed that this biotite was probably formed before the $\mathrm{C \#}$ deposition in the basin. The wide and flat plateaus in the $\mathrm{Ar} / \mathrm{Ar}$ geochronology data of $\mathrm{C} 2$ biotite point towards a simple crystallization history without any recrystallization events. The obtained ages $(17.37 \pm 0.04$ and $17.63 \pm 0.02 \mathrm{Ma})$ therefore roughly correspond to their crystallization. Accordingly, any older formations containing biotite and/ or quartz (all Proterozoic and Paleozoic metamorphic and magmatic formations of Bohemian Massif) must be excluded from further consideration. The studied time interval, however, post-dates the extinction of the two main volcanic complexes in the Ohře Rift (e.g. Ulrych et al., 2011) and includes the period when only minor scattered basaltic eruptions occurred more than $100 \mathrm{~km}$ east of the Most Basin (the Jičín Volcanic Field, Rapprich et al., 2007). Small volumes of dry basaltic magmas with low explosivity could not have produced so much biotite and distributed it over such a large area. Similarly, volcanic eruptions occurring in that time along the Rhine Graben in Germany were mostly effusive associated with rather small explosive eruptions (e.g. Lippolt, 1983). The large eruptions of alkaline magmas in French Massif Central, which could distribute pyroclastic material over the vast area are on the other hand at least by some 6My younger (e.g. Baubron and Demange, 1982). The lower Miocene was a period when volcanic activity in Carpatho-Pannonian region started (Pécskay et al., 2006). After the earliest intrusions around 23Ma, volcanic activity started there at $21 \mathrm{Ma}$ and lasted until sub-recent times. Besides numerous volcanoes with remarkable morphology in the Carpathian arc, there were other volcanic centers in the Pannonian Basin, now buried by sediments (Fig. 1C). Volcanic products and, to a limited extent, some volcanic edifices were partly revealed by drilling and geophysical surveys (e.g. Zelenka et al., 2004). Some of thevolcanoes produced widespread ignimbrites, outcropping on the margins of the Pannonian Basin. This is also the case of the so-called Middle Tuff Complex (MTC) exposed on the Bükk Foreland (Fig. 1C). This volcanic sequence consists of at least two, or maybe even three ignimbrite units, which erupted in the time interval 17.5-16.0Ma (Szakács et al., 1998). The source vent of these ignimbrites was inferred to be located east of Bogács and south of Harsány towns $(580 \mathrm{~km}$ ESE from the Most Basin) with the main direction of pyroclastic transport towards the west. In addition, a pyroclastic fall deposit correlated with the MTC was discovered on the boundary between Bohemian Massif and Carpathian Foredeep in northern Austria. This tuff ("Stranning ash", Fig. 1C) was dated using the Ar-Ar method on K-feldspar to $17.23 \pm 0.18 \mathrm{Ma}$ (Roetzel et al., 2014). The Austrian occurrence also contains abundant biotite, but K-feldspar was used for geochronology as a more suitable mineral phase. In the $\mathrm{C \#}$ beds in Most Basin, K-feldspar was not found. As the biotite and K-feldspar differ in atmospheric transport, biotite from volcanic eruptions can be distributed over larger distances, while K-feldspar could not reach the Most Basin. Alternatively, the K-feldspar from MTC eruption could have also been deposited in the Most Basin but might have been completely altered (Fig. 6E).

The ${ }^{40} \mathrm{Ar} /{ }^{39} \mathrm{Ar}$ age of biotite in C2 is by about $400-500 \mathrm{ky}$ older than the $\mathrm{C} 2$ bed dated by integrated cyclostratigraphic/

TABLE 4. Chemical composition of biotite from sandy laminae of C\# beds

\begin{tabular}{|c|c|c|c|c|c|c|c|c|c|c|c|}
\hline sample & $\mathrm{O}$ & $\mathrm{Na}$ & $\mathrm{Mg}$ & $\mathrm{Al}$ & $\mathrm{Si}$ & $\mathrm{Cl}$ & $\mathrm{K}$ & $\mathrm{Ti}$ & $\mathrm{Mn}$ & $\mathrm{Fe}$ & Total \\
\hline Cr-07 (C2 Libouš Mine) & 37,89 & 0,36 & 5,27 & 7,54 & 16,77 & 0,19 & 6,39 & 2,87 & & 18,37 & 95,65 \\
\hline Cr-09 (C2 Bílina Mine) & 37,89 & 0,30 & 5,35 & 7,53 & 16,84 & 0,19 & 6,25 & 2,64 & 0,02 & 18,64 & 95,66 \\
\hline Cr-10 (Greigite hor. Jiří Mine) & 38,88 & 0,11 & 5,12 & 10,16 & 16,80 & & 7,75 & 1,94 & 0,07 & 15,32 & 96,15 \\
\hline
\end{tabular}

\begin{tabular}{llll}
\hline sample & $\mathrm{K} / \mathrm{Ti}$ & $\mathrm{Al} / \mathrm{Si}$ & \\
\hline Cr-07 (C2 Libouš Mine) & 2,22 & 0,45 & av. of 15. spectra \\
Cr-09 (C2 Bílina Mine) & 2,37 & 0,45 & av. of 15. spectra \\
Cr-10 (Greigite hor. Jiří Mine) & 2,22 & 0,45 & av. of 15. spectra \\
\hline
\end{tabular}


paleomagnetic methods (17.06Ma, Matys Grygar et al., 2014, 2017), and there is also a mismatch of ${ }^{40} \mathrm{Ar} /{ }^{39} \mathrm{Ar}$ age of biotite in $\mathrm{C} 2$ with $\mathrm{K}$-feldspar Ar-Ar geochronology of Straning tuff (17.23 $\pm 0.18 \mathrm{Ma}$, Roetzel et al., 2014). On the other hand, within the error given, the age of the Straning tuff matches well the cyclo-/magnetostratigraphy-based age of the C1 bed (17.31Ma, Matys Grygar et al., 2014, 2017). The discrepancy between K-feldspar and biotite ArAr ages was already noticed from many volcanic systems (e.g. Bachmann et al., 2007; Spell and Harrison, 1993). Systematic research comparing biotite and sanidine ArAr geochronology under control of independent method $\left({ }^{238} \mathrm{U}-{ }^{230} \mathrm{Th}\right.$ disequilibria) revealed a systematic shift of 200-500ky in biotite Ar-Ar ages even for very young ( $<50 \mathrm{ka})$ volcanic products due to Ar partitioning and preeruption closure in biotite (Hora et al., 2010). This effect is highly pronounced namely in cases of young (Neogene) geological events, while in older samples this discrepancy is comparable to analytical uncertainty. Considering this systematic bias of the biotite Ar-Ar geochronology, the analytical ages of $\mathrm{C} 2$ beds are in broad agreement with other methods and confirm the possible volcanic origin of the biotite settled at the base of $\mathrm{CH}$ beds. Association of biotite with quartz and transformed feldspar is not in contradiction with silicic volcanic origin.

\section{Origin of authigenic compounds}

Because phosphorus has no specific indicator of its origin, we initially focused on possible fingerprints of other element constituents of the crandallite. In the Most Basin sediments, $\mathrm{Sr}^{2+}$ and $\mathrm{Ba}^{2+}$ ions for $\mathrm{C \#}$ beds were incorporated from the pore- and lake water. In the case of $\mathrm{Sr}^{2+}$, this mechanism would explain the prominent decrease of $\mathrm{Sr}$ and $\mathrm{P}$ concentrations in the monotonous lacustrine clay layer covering the C\# beds (Matys Grygar and Mach, 2013; this paper, Fig. 3). The Sr depletion above the C\# beds was proposed to identify them, in particular when the beds themselves were destroyed mechanically during drilling or overlooked in sampling (Matys Grygar and Mach, 2013). The Sr depletion is not observed below the C\# beds, which demonstrates the Sr was not brought to the C\# beds by postdepositional diffusion from surrounding sediment.

\section{${ }^{87} \mathrm{Sr} /{ }^{86} \mathrm{Sr}$ isotope ratio and $\mathrm{C \#}$ provenance}

The $\mathrm{C} \#$ beds show minimal differences in $\mathrm{Sr}$ isotope ratio relative to a wide scatter of $\mathrm{Sr}$ isotope signatures in rocks relevant for the Most Basin (Fig. 9; Table I). Samples of various clays of the Osek, Lom, Holešice, and Libkovice members were also analyzed to find the extent of variability in ${ }^{87} \mathrm{Sr} /{ }^{86} \mathrm{Sr}$ isotope ratios of the Most Formation sediments.

We used ${ }^{87} \mathrm{Sr} /{ }^{86} \mathrm{Sr}$ to find sources of other soluble matter inputs to the basin. The $\mathrm{Sr}$ isotope datasets used for comparison were obtained in the literature on the areas of the Most Basin catchment that were the main source of water and clastic material for the Most Basin fill during its lacustrine evolution stage (Mach et al., 2014). The ${ }^{87} \mathrm{Sr}^{86} \mathrm{Sr}_{17}$ in crandallite differs significantly from common volcanic rocks (mainly alkali basaltic rocks) of the Ohře Rift (Ackerman et al., 2015; Holub et al., 2010; Rapprich and Holub, 2008; Ulrych et al., 2002). Only some fractionated phonolites show higher ${ }^{87} \mathrm{Sr} /{ }^{86} \mathrm{Sr}_{17}$. These rocks are very poor in $\mathrm{Sr}$ and form small rock bodies that could not have provided enough material to change the $\mathrm{Sr}$ isotopic ratios of the Most Basin sediments. All these facts make it possible to exclude the Ohře Rift volcanic rocks from possible sources of authigenic components of crandallite beds. This comports with the lack of high contents of typical mafic "volcanogenic" elements such as $\mathrm{Ti}, \mathrm{Ni}, \mathrm{Cr}$, and $\mathrm{Cu}$ in any parts of the $\mathrm{CH}$ beds when compared with the surrounding clays. On the other hand, the isotopic characteristics of the crandallite beds are very close to that of carbonates, and also silicic residua after leaching carbonate from the marine sediments of the Bohemian Cretaceous Basin (0.707353-0.708271, Nádaskay et al., 2019 and newly obtained data). The $\mathrm{Sr}$ isotopic ratios of the Cretaceous deposits partly overlap with the presentday waters of European rivers (the Donau River= 0.70886, Veizer, 1993; the Odra River=0.7010-0.7108, Zieliński et al.,, 2017). The isotopic signature of $\mathrm{C \#}$ beds is also close to that of Miocene (17Ma) seawater ${ }^{87} \mathrm{Sr} /{ }^{86} \mathrm{Sr}$ (McArthur et al., 2001). The isotopic signature and namely amounts of $\mathrm{Sr}$ available from the Cretaceous sediments could suggest that most of the $\mathrm{Sr}$ in $\mathrm{CH}$ originated from chemical weathering of the Cretaceous rock outcrops. We expect that carbonate shells (with high amounts of Sr, Nádaskay et al., 2019) in outcrops of marlstones and claystones were weathered and leached preferentially. The shift in $\mathrm{Sr}$ isotopic signatures of the crandallite beds from that typical of Cretaceous rocks towards more radiogenic values in the clays can be explained in terms of admixture of more radiogenic strontium. As all the $\mathrm{Rb}$-rich rocks ( $\mathrm{Rb}$ produces radiogenic $\mathrm{Sr}$ signature) are poor in Sr, which could be mobilized during weathering, rather very small amounts of highly radiogenic strontium signature seem to be a good candidate to represent additional strontium derived from the Cretaceous rocks. In this aspect, granites and rhyolites of the Altenberg-Teplice Volcanic Complex with strongly elevated ${ }^{87} \mathrm{Sr} /{ }^{86} \mathrm{Sr}$ values (except for their early stages with less radiogenic signatures, Walther et al., 2016) would have potential to modify the ${ }^{87} \mathrm{Sr} /{ }^{86} \mathrm{Sr}$ ratio in the Most Basin paleolake.

In contrast to the $\mathrm{C} \#$ beds, the trend of clastic sediments of the Main Coal Seam in ${ }^{87} \mathrm{Sr} /{ }^{86} \mathrm{Sr}_{17}$ vs $\mathrm{Sr}$ (Fig. 9) follows that of metamorphic basement and granitic rocks of carboniferous age occurring in potential watershed. It can be explained by a difference in conditions in the lake during the formation of $\mathrm{CH}$ beds and deposition of clastic 
sediments. The crandallite beds exclusively incorporated $\mathrm{Sr}$ dissolved in lacustrine water (mostly originating from the Cretaceous rocks), while the monotonous lacustrine clays incorporated more detritic grains from non-carbonate rocks. The negative correlation between the $\mathrm{Sr}$ contents and ${ }^{87} \mathrm{Sr} /{ }^{86} \mathrm{Sr}_{17}$ ratios (Fig. 9) thus suggests the mixing of two contrasting sources. A source poor in Sr, but with highly radiogenic signature (gneisses and namely granites or rhyolites), dominates over the source of less radiogenic strontium (the Cretaceous sediments and possibly also Ohře Rift volcanic rocks). The higher $\mathrm{Sr}$ contents in monotonous lacustrine clays is accompanied by a higher $\mathrm{P}, \mathrm{Ca}$, and $\mathrm{Ba}$ contents and so we can deduce that this extra $\mathrm{Sr}$ has the same form as $\mathrm{Sr}$ in $\mathrm{C \#}$ beds, crandallite, with $\mathrm{Sr}$ originating from the lake water. Within clays containing less than 70ppm $\mathrm{Sr}$, the clastic signal prevails; this comes from weathered Paleozoic acid magmatic rocks and metamorphic rocks of SW part of the Bohemian Massif, the main source of clastic sediment components in the Most Basin fill. The isotopic composition of this $\mathrm{Sr}$ is also similar to that of Proterozoic gneisses of the Krušné Hory Mts. (Table I).

Sr isotopes help explain mixing of inorganic sources of basin inputs. The other question is how and in which conditions authigenic minerals precipitated; methods including REE spectra, stable $\mathrm{C}$ and $\mathrm{O}$ isotopes in carbonate, and organic geochemistry analyzing provide insight.

\section{Conditions of crandallite precipitation}

Generally, crandallite is a mineral, which requires quite specific conditions to be formed (Dill, 2001). Relatively minor differences in solution acidity around a $\mathrm{pH}$ value of 7 controls whether apatite (in alkaline medium) or crandallite (in acid medium) is precipitated. With higher $\mathrm{HPO}_{4}{ }^{2-}$ activities, acidic environment (to $\mathrm{pH}=5$ ) are needed for the crandallite precipitation. The crandallite physical-chemical stability was examined especially in weathering crusts including phosphate deposits. Unlike more ubiquitous Caphosphates of the apatite group, which are stable in neutral or slightly acidic conditions with a sufficiently high $\mathrm{PO}_{4}^{3-}$ anion activity, crandallite is stable in more acidic conditions ( $\mathrm{pH}$ between 6.5 and 5.5). Besides sufficient availability of phosphate ions, the presence of $\mathrm{Al}^{3+}$ or $\mathrm{Al}\left(\mathrm{OH}_{2}\right)+$ is necessary for crandallite crystallization (Huang and Keller, 1972; Vieillard et al., 1979). Crandallite crystals scavenge $\mathrm{Sr}^{2+}$ and $\mathrm{Ba}^{2+}$ and other larger cations from surrounding solutions, substituting them for $\mathrm{Ca}^{2+}$ cations in its crystal lattice (May et al., 1963). Thus, crandallite commonly occurs as a solid solution with $\mathrm{Sr}$ - or Ba-rich isostructural minerals goyazite and gorceixite, respectively.

REE concentrations normalized to chondrite (Fig. 8A; Boynton, 1984) and North American Shale Composite (Fig. 8B; NASC, Haskin and Haskin, 1966) show significant positive Eu anomalies, attributable to special chemical properties of $\mathrm{Eu}$ within the lanthanides group. Europium usually existing in poorly water-soluble $\mathrm{Eu}^{3+}$ form can be under certain conditions reduced to more soluble $\mathrm{Eu}^{3+}$. The specific conditions of crandallite precipitation (reduction by organic matter, a narrow interval of acidity, high phosphate activity) enabled its extraction from detritic minerals like monazite. Subsequently, its reduced form $\left(\mathrm{Eu}^{2+}\right)$ became available for incorporation into crandallite, analogous to $\mathrm{Sr}^{2+}$ or $\mathrm{Ba}^{2+}$. This presumption is in good agreement with observations from organic geochemistry, which provided evidence of high bacteria/algae activity at the lake bottom during crandallite precipitation. Disparate conditions for $\mathrm{C} 1$ formation in the Libouš Mine area are reflected in differences in mineralogical composition (high content of detritic clay minerals and authochthonous siderite) and bed thickness. Europium is thus a sensitive indicator of crandallite precipitation conditions across the basin. The Ce-anomaly (defined as $\log \left[\mathrm{Ce} / \mathrm{Ce} e^{*}\right]$, where $\mathrm{Ce} / \mathrm{Ce} *=$ $3 \times \mathrm{Ce}_{\mathrm{N}} /\left(2 \times \mathrm{La}_{\mathrm{N}}+\mathrm{Nd}_{\mathrm{N}}\right)$; normalized to the North American Shale Composite (NASC) of Haskin and Haskin (1966) was used by Elderfield and Pagett (1986) to distinguish between oxic and anoxic conditions during phosphorite sedimentation, with boundary set at zero. Wright et al. (1987) then modified the redox boundaries to anoxic/ transitional for $\mathrm{Ce}$ anomaly of 0 and transitional/oxic for $\mathrm{Ce}$ anomaly of -0.1 . Ce-anomaly values for $\mathrm{C} 1$ precipitates for Bílina and Libouš Mine at 0.06 and 0.09 , respectively suggest anoxic conditions at the lake bottom during the C1 bed sedimentation, whereas values of this anomaly in the range $-0.01--0.03$ indicate transitional oxic/anoxic conditions for sedimentation of remaining $\mathrm{CH}$ beds.

$\mathrm{C}$ and $\mathrm{O}$ stable isotopic ratios in the $\mathrm{C} 1$ contained in siderite can be compared with data obtained in earlier studies (Mach et al., 2001, R. Lojka, unpublished data of carbonates dispersed in clays of the Most Formation above the main coal seam, data overview in Figure 10). In the $\delta^{13} \mathrm{C} / \delta^{18} \mathrm{O}$ graph, the newly-studied $\mathrm{C} \#$ plot along the border of the main field of diagenetic carbonates. Graph subarea of $\mathrm{C} 1$ samples is extreme by lower values of both $\delta^{13} \mathrm{C}$ and $\delta^{18} \mathrm{O}$ (Fig. 10). It shows slightly different conditions of its formation, than in the case of dispersed carbonates. Interestingly the siderite from $\mathrm{C} 1$ in the Libouš Mine differs from carbonates of the Libkovice Member clays from both central and Bílina parts of the basin and especially from the samples from the drill core SP257 (black points in Fig. 10) situated near the $C 1$ sampling site (Fig. 1). Isotopic compositions of clays from the Holešice Member in the central part of the basin (yellow rectangles in Fig. 10) are nearer to siderite in $\mathrm{C} 1$. Nevertheless, $\mathrm{C} 1$ siderites were formed by the same manner as siderites in lacustrine silty clays of the Libkovice or Holešice members, i.e. early after sedimentation. As preceding studies assumed (Mach et al., 2001), the isotopic, mineralogical, and chemical signatures 
of carbonates formed in more extreme conditions are more different. Siderite of the $\mathrm{C} 1$ bed thus precipitated during early diagenesis in slightly higher temperature, different acidity, and more reduction conditions than carbonates dispersed in the surrounding monotonous lacustrine clays, any case not in the zone of prevailing methanogenesis or sulfate reduction. The high content of siderite in the upper part of C1 (up to $50 \%$ ) shows, that phosphate-containing sediment was very porous in the time of carbonate crystalization, also in the agreement with high porosity calculated from C\# bulk density of other samples. The very high porosity of the $\mathrm{C} 1, \mathrm{C} 2$ and $\mathrm{C} 3$ crandallite rock reaching $66 \%$ of sample volume documents presence not only of water in pores but also some other material existing in pores before and during crandallite precipitation; the material subsequently diluted or consumed diagenetically. The most probable explanation of this material would be organic matter later consumed by bacteria, finally removed in the form of $\mathrm{H}_{2} \mathrm{O}, \mathrm{CO}_{2}$ and $\mathrm{C} 4$ as products of their metabolism.

GC/MS analyses of the extractable organic compounds indicate significant differences in $\mathrm{C \#}$ beds in comparison with the surrounding sediments and demonstrate different conditions of their formation. The reduced TAR values (Fig. $11 \mathrm{~A}$ ) indicate a higher algal presence and bacterial activity compared to the surrounding clays. Decreased $\mathrm{Pr} / \mathrm{Ph}$ values in C\# beds (Fig. 11B) can be interpreted as evidence of a significantly reducing environment during phosphate bed formation. Similarly, $\mathrm{Pr} / n-\mathrm{C}_{17}$ and $\mathrm{Ph} / n-\mathrm{C}_{18}$ ratios based on higher resistance of $\mathrm{Pr}$ and $\mathrm{Ph}$ compared to n-alkanes (Fig. 10C, D) show that C\# beds, having higher ratios, endured more significant bacterial degradation of organic matter than in the surrounding clays. Finally, the higher proportion of shorter-chain fatty acids (Fig. 11E) documents, similarly to TAR, increased presence of bacterial-algal mass entering the set of organic compounds in $\mathrm{C \#}$ beds.

Stable $\mathrm{C}$ and $\mathrm{O}$ isotopes together with organic geochemistry and REE patterns define the conditions of crandallite and carbonate precipitation. These minerals precipitated in anoxic to transitional anoxic/oxic conditions surrounded by organic matter decomposing by vigorous bacterial activity. Organic matter was prevalently of bacterial or algal origin.

\section{Prerequisites for C\# bed formation: phosphate accumulation and environmental disruptions}

We principally envisage the origin of crandallite in three ways:

1. crandallite grains were detritic, transported to the lake by rivers,

2. crandallite precipitated in the water column and then deposited on the bottom of the lake,
3. crandallite is a product of transformation of some other source of phosphate within the sediment.

The first hypothesis is unsupported, no such significant source of crandallite is known within potential source areas. It is also questionable whether crandallite could be transported for such long distances without dissolution in water and dilution by detritus. If there were to be some source, e.g. older kaolinic weathering crust, the crandallite would be diluted by a larger amount of clay minerals, which was not the case in $\mathrm{C \#}$ beds.

The second possibility would require an abundant source of diluted phosphate in lacustrine water together with high concentrations of $\mathrm{Al}^{3+}$ and $\mathrm{Ca}^{2+}$ cations and special acidic conditions (Vieillard et al., 1979) in the water column. Under usual lacustrine conditions phosphate is primarily a part of its biogenic cycle bound in living organisms, which tend to recycle this nutrient as soon as possible after death of organism and their decomposition. Persistent combination of high activities of all needed chemical components and acidic conditions in the column lacustrine water is not probable.

The third idea is most probable for the lake in the Most Basin (Fig. 12). We propose that dead organisms (especially algae and bacteria according to our results) accumulate on the lake bottom, where anoxic bacterial decomposition under acidic conditions make crandallite precipitation possible. Low $\mathrm{pH}$ produces $\mathrm{Al}^{3+}$ from clay minerals from suspension fluvially transported to the lake. Acidic decomposition of clay minerals would also produce amorphous $\mathrm{SiO}_{2}$, indeed found in $\mathrm{C \#}$ beds by XRD and chemical analysis. Apatite containing skeletons from higher organisms could contribute phosphate beside phosphate from soft tissues of all organisms. The lack of the original bone structure in the crandallite bed could be explained by recrystallization of the original biogenic apatite similarly as reported by Dericquebourg et al. (2019). Geochemical data obtained from above described analysis like organic geochemistry, REE geochemistry and C, O stable isotope geochemistry document intensive decomposition of organic matter under acidic anoxic conditions.

An enigmatic aspect is the fixation of such a large amount of $\mathrm{P}$ from biogenic cycle in the Most Basin. How could such a large amount of a "phosphate concentrate" be so regularly deposited on the bottom of the basin-wide lake? The limiting factor for any of the hypothetic processes responsible for crandallite bed formation would be the quantity of the biogenic material needed. To create a $2 \mathrm{~cm}$ thick $\mathrm{C} 2$ bed containing $9 \%$ of phosphorus in the Most Basin, ca. $2 \mathrm{~kg}$ per $1 \mathrm{~m}^{2}$ of phosphorus must have been deposited on the lake bottom (using dry density around $1 \mathrm{~g} / \mathrm{cm}^{3}$ obtained for non-sideritized beds). According to Whittaker and Likens 
in Lieth and Whittaker (1975), normal lacustrine primary production of organic matter is $0.1-1.5 \mathrm{~kg}$ of dry mass (or $0.02-0.95 \mathrm{~kg}$ of $\mathrm{C}$ ) per $\mathrm{m}^{2}$ and year (mean $0.4 \mathrm{~kg}$ of dry mass per $\mathrm{m}^{2}$ and year), depending on the distance from the tributary river mouths. Depending on the form of biomass, the $\mathrm{P}$ content can vary from 0.5 to $5 \%$. The measured state of biomass content was 0.0 to $0.1 \mathrm{~kg}$ per $\mathrm{m}^{2}$ after Whittaker and Likens in Lieth and Whittaker (1975). The stoichiometric content of $\mathrm{P}$ in freshwater fish bodies is usually in the range of $1.3-5.7 \%$, averaging $2.9 \%$ in dry mass (McIntyre and Flecker, 2010). Similar data for invertebrates (Evans-White et al., 2005) gives phosphorous content in the interval of 0.3 to $1 \%$ in dry mass. Data for 5 species of freshwater zooplankton from the Kjelsiisputten Lake, Norway given by Hessen and Andersen (1990) are in the interval of 0.6-1.4\% of $\mathrm{P}$ in dry biomass. Taking a very rough average primary productivity of dry biomass as $0.4 \mathrm{~kg}$ per year (Whittaker and Likens in Lieth and Whittaker, 1975) and content of $\mathrm{P}$ in this mass to $1.5 \%$, we obtain $0.4 \times 0.015=0.0060 \mathrm{~kg} /$ $\mathrm{m}^{2}$. Similarly, the actually measured state of biomass around $0.05 \mathrm{~kg} / \mathrm{m}^{2}$ gives $0.05 \times 0.015=0.00075 \mathrm{~kg} / \mathrm{m}^{2}$ of $\mathrm{P}$. Another direct view to the potential $\mathrm{P}$ sources in lacustrine water is provided by an aggregate of $\mathrm{P}$ content in particles floating in lacustrine water. Hecky et al. (1993) published dataset on $\mathrm{P}$ content in seston for 51 recent lakes of various climatic regimes. According to this dataset, the $\mathrm{P}$ content in particles (including bioseston phyto and zooplankton, nekton etc.) is in the range 0.09 to $1.81 \mu \mathrm{mol} \cdot 1-1$ with a median value around $0.2 \mu \mathrm{mol} / \mathrm{l}=0.0002 \mathrm{~mol} / \mathrm{m}^{3}$. Accordingly, in a $10 \mathrm{~m}$ column of lacustrine water $0.0002 * 30.97 * 10=0.062 \mathrm{~g} / \mathrm{m}^{2}$ of $\mathrm{P}$ could potentially be in particle source, which can at any one moment be deposited onto the lake bottom.

Roughly estimated values of potential $\mathrm{P}$ sources in lacustrine water calculated by various methods (above) scatter across a few orders of magnitude and reach a maximum of a few grams of $\mathrm{P}$ per $\mathrm{m}^{2}$ and year. In any case, they show that it was not possible to form $\mathrm{C} 2$ bed by a single-event extinction of all lacustrine organisms. A longer deposition of $\mathrm{P}$ would thus be needed under normal lacustrine productivity, in particular lasting for a thousand years in the Most Basin C\# beds. The usual clastic sediment deposition rate of the Libkovice Member clay was in average $17-20 \mathrm{~cm} / \mathrm{ky}$ (Matys Grygar et al., 2014, 2017) thus a several-ky-long interval for the formation of C\# would represent a disruption on the order of tens $\mathrm{cm}$ to several meters of the sediment condensed to a few $\mathrm{cm}$, something that could not be revealed by the integrated magneto-/cyclostratigraphy age model for the entire $200 \mathrm{~m}$ of clays of the Libkovice Member (Figs. 2; 3).

Considering all facts and assumptions above, the $\mathrm{C \#}$ beds can be interpreted as the sediment-starved intervals, with the usual clastic input temporarily suppressed and lacustrine deposits formed mainly by biogenic/ autochthonous chemogenic components (Fig. 12). One possible condition enabling a radical decrease of clastic input to the basin would be unusual seasonal stability of climatic conditions in the catchment area. If the seasons have differed minimally, flooding conditions crucial for clay suspension forming in watershed and transport to the lake could have been absent. Such a climatic regime could be imagined in periods of the weakest seasonal contrasts, i.e. either during minimal eccentricity of the Earth orbit and minimal obliquity of the Earth rotational axis, or maximal eccentricity with the Earth in perihelion in winter and aphelion in summer according to the actual precession (cycle ca. 20ky). Especially occurrences of $\mathrm{C} 1$ and C2 together with C' and C" fall very well (Fig. 3) to the latter pattern periods (Matys Grygar et al., 2017). The coincidence of eccentricity maximum and $\mathrm{C \#}$ bed is apparent in the case of $\mathrm{C} 1, \mathrm{C} 1 \mathrm{a}$ and $\mathrm{C} 3$. The precise timing of $\mathrm{C} 2$ is within one precession cycle near an eccentricity maximum. It is necessary to mention here crandallite dispersed in the lacustrine sediments also in Sr maxima outside $\mathrm{C \#}$ beds documents the chemical conditions were favorable for crandallite formation in the entire lacustrine deposition.

At first glance, it is hard to judge whether these stable climate periods were humid or dry. Stable humid climate could result in very dense plant cover of the catchment with minimal physical erosion and intense pedogenetic hydrolysis of minerals rather than their transformation to clay minerals, lack of slope erosion, vegetation covering rock outcrops, and stable vegetated riverbanks limiting floodplain reworking. Eutrophication of the lake in pluvial with development of sub-oxic or anoxic conditions in the lake bottom would prevent $P$ recycling by aquatic organisms and favor bacterial metabolism in the lake bottom as it was proposed by Dericquebourg et al. (2015) for similar phosphate accumulation in African lacustrine sediments.

On the other hand, stable dry periods could produce very limited detritic input, transport by aeolian rather than fluvial processes. Both such conditions would considerably decrease clastic input. Either huge explosive volcanic events, or dry climatic events with an associated aeolian process could produce the regular, continuous, thin sandy laminae without any ripples or deformational balls and

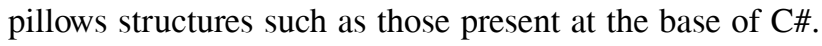
Results of organic geochemistry analyzes support the "dry periods" hypothesis by higher content of organic matter having its origin in autochthonous (bacterial and algal) input in relation to allochthonous sources in the basin watershed. Lower content of terrigenous organic matter is associated with lower input not only of clastic sediment components, but also of water generally.

We cannot exclude other possibilities explaining the close relations of $\mathrm{C} \#$ beds occurrences and general 

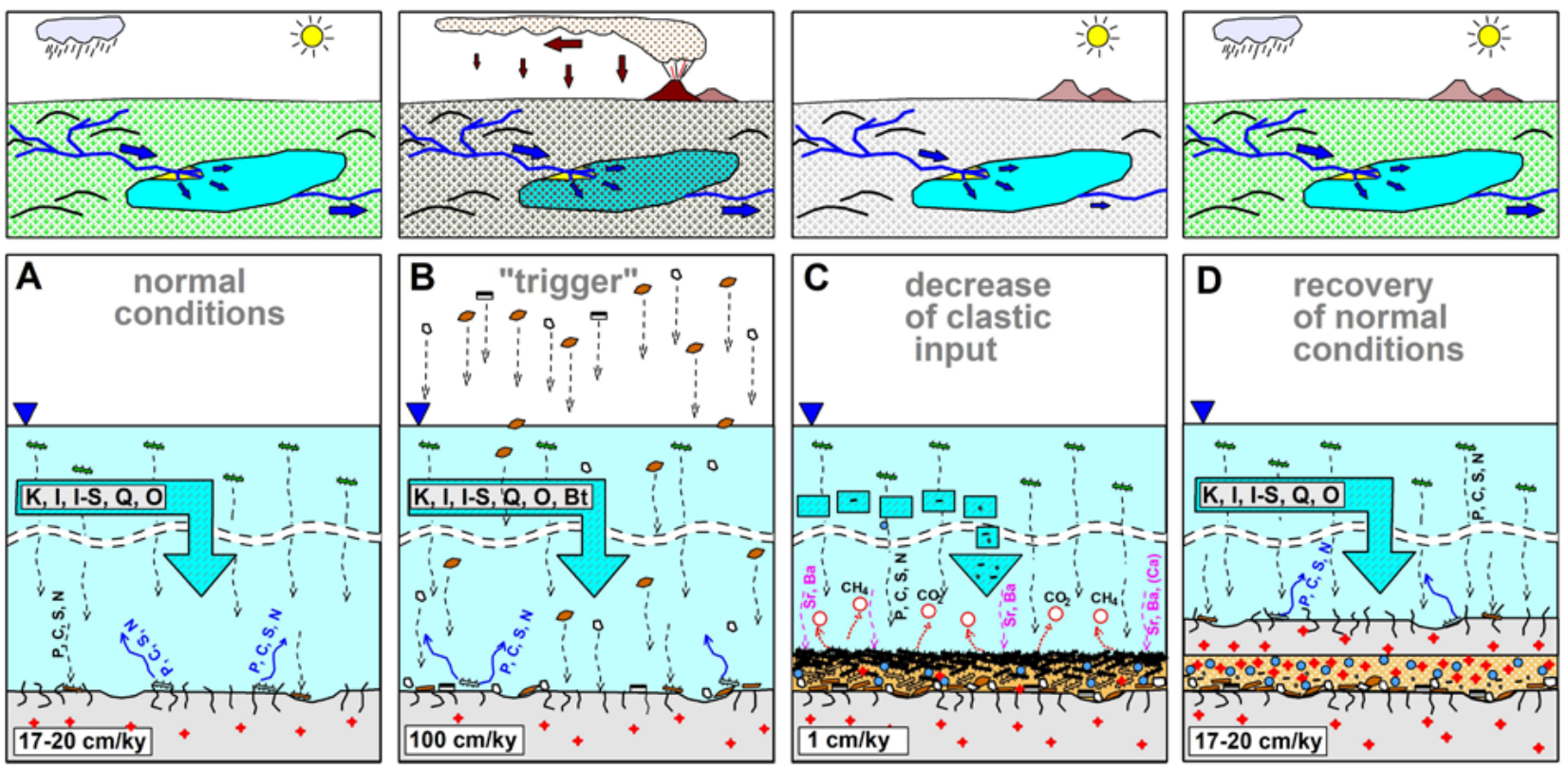

Usual silty clay sedimentation
from suspension, accompanied
by bioproduction and recycling
of dead organic material.
Intensive bioturbation by
invertebrates. Crystalization
of authigenic siderite in pores
within bottom sediment.

Volcanic ash fall or extraordinary strong aeolian event. Formation of quartz/biotitel feldspar laminae. Dispersion and in wathershed too. Interruption of sediment bioturbation.

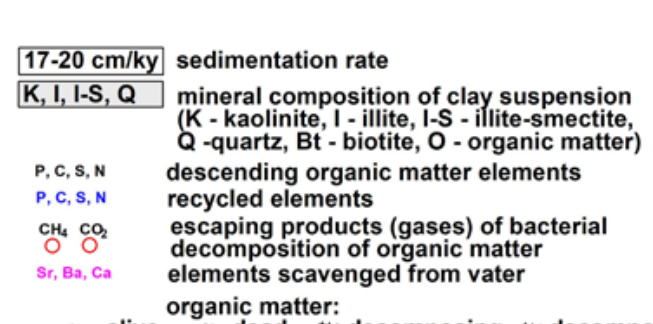

- alive organic matter:

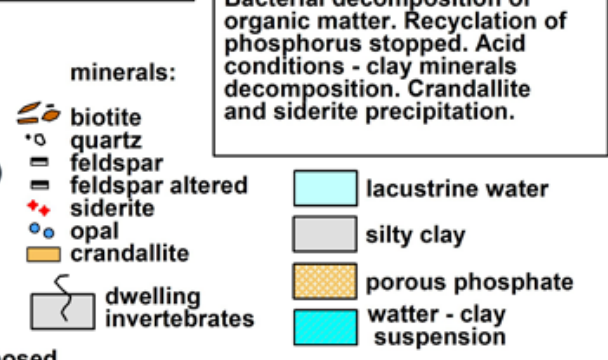

Abrupt decrease of clastic input to the lake. Apart from clay minerals volcanogenic minerals from ash fall form a part of transported suspension with finer granularity. Bioproduction going on + accumulation of organic matter on the bottom. Bacterial decomposition of phosphorus stopped. Acid conditions - clay minerals decomposition. Crandallite
Recovery of normal clastic

Recovery of normal clastic of biogenous elements. Return of invertebrates dwelling Lack of diluted $\mathrm{Sr}$, Ba in water.

vegetation

vegetation ash fall vegetation affected vegetation affected
by climatic change

$\rightarrow$ water stream

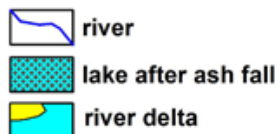

FIGURE 12. Principal scheme of crandallite bed origin (version of change to dry stable climate). Upper part of the figure — schematic paleogeographic conditions, lower part of the figure - schematic crossections through column of water and the topmost part of sediment. A, B, C, D, main stages of the process of crandallite bed formation.

geochemical characteristics of $\mathrm{K} / \mathrm{Al}, \mathrm{Al} / \mathrm{Si}, \mathrm{Ti} / \mathrm{Al}, \mathrm{Mg} / \mathrm{Al}$ or cation exchange capacity. Changes of some geochemical parameters - proxies of mineralogical composition of clay sediment during that time - can be explained in other ways. One such idea involves autocyclic processes working in the lake especially the changing of deltas and depocenters position within basin. Evidence of this can be found in local lakes and of Holešice Member deltas, especially case of Bílina Delta (Dvořák and Mach, 1999; Rajchl and Uličný, 1997). Conditions in local lakes surrounded by peat swamp is rather different from the whole basinwide lake represented by sediments of Libkovice Member excluding the topmost part of Holešice Member, 10-20m thick Břešt'any Clays. Břešt'any clays as a widespread layer represent the stage of expansion of the local lakes, their interconnection and creation of one basin-wide lake covering the entire Most Basin. The two topmost delta fans connected to these basin-wide clay layers were documented in southern part of Bílina Mine (Dvořák and Mach, 1999). Bottom part of Břešt'any Clays is split by wedges of these delta bodies. Břešt'any clays differ from Libkovice Member clay only by absence of illite-smectite in its composition on major part of the basin. Some portion of smectite structures occur only in the central part of the Most Basin between ČSA Mine and Most, where it is present in lower half profile of this layer. It was detected by higher values of cation changing capacity (Fig. 2). This Illite-smectite area is located approximately $15 \mathrm{~km} \mathrm{~W}$ of the abovementioned delta bodies in the area of Bílina Mine. This situation gives rise to the possibility that at the scale of the Most Basin some lateral changes of lacustrine sediment composition caused by different rates of various clay 
minerals sedimentation depending on the distance from the deltas. Consequently, changing clay composition within the profile could be the result of changing delta position. Delta position changes were identified as being caused by changes in water level in the lake (Rajchl and Uličný, 1997). On the other hand, we found that content of illite-smectite in the Libkovice Member clays well documented by cation changing capacity is not dependent on the Illite, kaolinite and silt of quartz content in the clay displayed by $\mathrm{K} / \mathrm{Al}$ (Mg/Al) or $\mathrm{Al} / \mathrm{Si}$ relations (Matys Grygar et al., 2019a). This fact was then confirmed by methods of lithological correction of previous results (Matys Grygar et al., 2020). Stated simply, the suspended fractionation within the lake is only one but not the main reason of clay mineral composition variations in the profile. Because occurrences of $\mathrm{C \#}$ beds are specifically related to $\mathrm{K} / \mathrm{Al}$ stratigraphy led by Milankovich cycles of orbital Earth parameters (Matys Grygar et al., 2017) and not to other parametres closed to physical properties of sediment we can exclude some autocyclic reason of its formation as the main reason.

Close relation of $\mathrm{C} \#$ beds cooccurrence with $\mathrm{K}$, minima is not sole fact supporting the idea of climatically driven phosphate accumulation. Likewise, it can be supported by the co-occurrence of several meter thick layers of clay with several times higher content of phosphates (indicated as $\mathrm{Sr}$ anomalies) and layers with increasing of $\mathrm{Al} / \mathrm{Si}$ ratio of sediment (Fig. 3). The $\mathrm{Al} / \mathrm{Si}$ variation in the class of the Libkovice Member represents another form of climatically driven cyclicity similar to the $\mathrm{K} / \mathrm{Al}$ ratio. Higher $\mathrm{Al} / \mathrm{Si}$ in $\mathrm{K} /$ Al minima indicates higher contents of kaolinite that can be interpreted as higher intensity of chemical weathering (deeper hydrolysis of clay minerals) in the watershed.

Noteworthy from an environmental point of view are also the chemical pre-requisites for the crandallite crystallization. It needs a pH of 5.5 to 6.6 , lower than apatite depending on the phosphate ion activity (Dill, 2001). Such a slightly acid solution would prevent the precipitation of calcite and common Ca-phosphates. Global acidification was apparently among the general geochemical aspects of global environmental crises related to volcanism (BorruelAbadía et al., 2019). If such a crisis was behind C\# formation, it could also explain the basin-wide biotic crisis needed to remove a sufficient amount of $\mathrm{P}$ from biogenic recycling. This crisis alone cannot explain the persistent deficit of clastic input to the lake. Occurrence of invertebrate bioturbation in the overlying and underlying clays together with the lack of bioturbation in the $\mathrm{C \#}$ beds could be the result of reducing/acidic conditions during the formation of the $\mathrm{C \#}$ beds. Reducing conditions are documented also by $\mathrm{Pr} / \mathrm{Ph}$ ratios in $\mathrm{C \#}$ beds and surrounding clays.

A very interesting aspect of all $\mathrm{C \#}$ beds is the sudden re-establishment of the clay sedimentation after the crandallite-formation interval (Fig. 6B, C, J). This can be connected only with a rapid change in the watershed conditions, maybe in combination with rapid progradation of the river deltas to the lake, with hyperpycnal suspension of clay brought again to the bottom of the lake, all under renewed oxidizing conditions documented by Planolites montanus occurrence. Such scenario would evidence extraordinarily rapid climate changes in the lower Miocene history.

Convolute bedding of Kelvin-Helmholtz (Fernando, 1991) and/or Rayleigh-Taylor type instabilities (Gladstone et al., 2018) described in the middle of C1 (Fig. 4F) could be interpreted as evidence of seismic activity during formation of the bed. The density contrast between the upper part of $\mathrm{C} 1$ bed (denser due to containing siderite filling pores) and the lower half of it (very porous, containing prevalent phosphate + clay minerals) led to a probable reaction to shear stress produced by seismic waves (Heifetz et al., 2005) generating typical billows (Fig. 4F).

Another subject of discussion can be formation of bottom sandy lamina of C\# beds. According to above-offered idea of formation of this lamina by falling its particles from the air to the water surface (by volcanic or aeolian event) and after that to the bottom of the lake. This process covers a wide area by very regular layers of sandy to silty material in a short time interval. We excluded the competing hypothesis of water because, in our opinion, the Holešice Member study (Dvořák and Mach, 1999; Rajchl and Uličný, 1997) showed that thin laminae of fine sand could be formed in lacustrine conditions only after transport of the sand by dense clay suspension. Such suspension sediments within the prodelta area in the form similar to turbidites, prodeltaic heteroliths. If the sand is not a part of suspension, it can be usually transported only by bottom transport (moving ripples) and in that case, it finishes its course just near the mouth of tributary on the delta front where the rate of water stream decreases suddenly. According to our observations, prodeltaic heteroliths containing thin sandy laminae produced by sedimentation from hyperpycnal suspension did not reach more than several hundred meters from delta front covering areas maximum of couple square kilometers often characterized by syndepositional deformations near the delta (balls and pillows or micro-ripples). Biotite containing laminae on the $\mathrm{C} \#$ beds cover hundreds square kilometers and have no signs of horizontal bottom transport like ripples. A typical sign of sandy laminae which are a part of prodeltaic heteroliths (turbidites) is their coupling with overburden clay bed formed in the second part of the process of turbidite flow sedimentation. Sandy lamina can't occur without normally graded clay bed in the overburden and usually, the clay portion is much thicker than the sand one. The biotite-containing sandy laminae have no clay cover in the case of $\mathrm{C \#}$ beds, it is covered by a phosphate 
layer. Another argument supporting the hypothesis of ash fall or aeolian origin of bottom sandy laminae is the relatively low degree of biotite weathering and usual form of its individua. They are very frequently represented by well-preserved crystals without any signs of destruction by transport or pre-sedimentary weathering. This can be hardly imagined on biotite that experienced protracted weathering and fluvial transport. Biotite was exclusively identified on the bottom of $\mathrm{C \#}$ beds within the whole profile of the Most Formation although it is common in rocks forming the Most Basin watershed. This means that any other biotite of the Most Basin watershed was completely transformed by weathering and destroyed by transport to the basin. We can therefore exclude water transport of biotite, quartz sandy material to the whole basin area.

\section{Role of volcanism in C\# formation}

The biotite in the basal strata of crandallite beds was of volcanic origin, suggesting some large volcanic eruptions coincided with the onset of crandallite precipitation (or accumulation of P-rich crandallite precursor). On the other hand, the climatic extremes lasting over several thousands of years could hardly be driven by a volcanic eruption. Similarly, the largest ever known volcanic eruption of Toba $(74 \mathrm{ka})$ preceded glaciation, but the volcanic winter resulting from the eruption only accelerated the advent of the glacial stage (Rampino and Self, 1992). Volcanism is a good hypothetic trigger of a sudden change of conditions in the catchment and the lake, in particular in the period of the Earth evolution approaching the onset of the Middle Miocene Climatic Optimum (MMCO), as this period was close to a global climate change. On the other hand, we cannot exclude the possibility of post-volcanic aeolian transport of volcanic products to the Most Basin by extraordinarily strong aeolian processes. This possibility can be supported by the content of probable glauconite grains within the basal sand mineral association.

\section{CONCLUSIONS}

Contrary to preceding works, we conclude that Sr- and Ba-bearing $\mathrm{Ca}-\mathrm{Al}$ phosphate beds in lacustrine clays of the Libkovice Member of the Most Basin resulted from climatic disruptions in periods of large orbital eccentricity and coincidence with other orbital factors, in particular a specific phase of precession cycles, by an unusually stable precipitation regime, i.e. a very low seasonality. C\# beds were formed in a sediment-starved interval under persistent dry or persistent humid climate. The climatic trigger for formation of the $\mathrm{C \#}$ beds in the Most Basin is supported by their association with $\mathrm{K}$ concentration minima driven by orbitally-controlled sedimentary cyclicity. The precipitation of the phosphate from biogenic precursors in contact with lacustrine water is proven by $\mathrm{Sr}$ isotopic signatures and depletion of the lacustrine clays above the $\mathrm{C} \#$ beds in $\mathrm{Sr}$, $\mathrm{Ba}$, and $\mathrm{P}$. The presence of biotite crystals of volcanic origin, mostly concentrated in the bed base remains enigmatic, but can be explained by two hypotheses: aeolian transport from rock outcrops (earlier volcanic ash fall) of the basin vicinity to the basin floor (under dry climate), or direct volcanic influence (under pluvial climate). Volcanic events could trigger several kiloyears-lasting environmental changes in the Libkovice paleolake body or watershed. The available data do not provide unequivocal evidence for preferring either of the two above proposed hypotheses for crandallite bed conditions: pluvial climate, or drought. The position of the $\mathrm{C} \#$ beds at the base of $\mathrm{K}$ minima would point to generally humid climate and bottom anoxia caused by lake eutrophication, and in this case the biotite-quartz sand on the bottom of the bed would require a coincidence with volcanogenic fallout. Both cases, however, represent extremes of the precipitation regime in the Most Basin catchment and could point to yet unidentified environmental disruptions around the time of the MMCO onset.

\section{ACKNOWLEDGMENTS}

We would like to thank all the people and institutions who helped to collect the samples and evaluate the presented data. North Bohemian mines j.s.c., SevEn j.s.c. and PKÚ s.c. companies allowed us to collect samples from the drill cores and mine outcrops from 2009 until present. Some unpublished datasets were provided by R. Lojka (Czech Geological Survey). Significant laboratory work was done by M. Heizler and his team from NMGRL, B. Čejková, I. Jačková, J. Hora, F. Laufek, V. Erban from the Czech Geological Survey, and J. Kapusta (Dept. of Geology, Faculty of Science, Palacký University Olomouc). Analytical works were supported by the North Bohemian mines j.s.c. and the Czech Geological Survey (project 310410). We are grateful to J. Hora for repeated revisions of the English text. Manuscript benefited from constructive comments by two anonymous reviewers.

\section{REFERENCES}

Ackerman, L., Ulrych, J., Řanda, Z., Erban, V., Hegner, E., Magna, T., Balogh, K., Frána, J., Lang, M., Novák, J.K., 2015. Geochemical characteristics and petrogenesis of phonolites and trachytic rocks from the České Středohoří Volcanic Complex, the Ohře Rift, Bohemian Massif. Lithos, 224-225, 256-271.

Bachmann, O., Oberli, F., Dungan, M.A., Meier, M., Mundil, R., Fischer, H., 2007. ${ }^{40} \mathrm{Ar} /{ }^{39} \mathrm{Ar}$ and U-Pb dating of the Fish Canyon magmatic system, San Juan Volcanic field, Colorado: Evidence for an extended crystallization history. Chemical Geology, 236, 134-166.

Baubron, J.C., Demange, J., 1982. First geochronological study of the volcanic plateau of Aubrac (French Massif Central)- 
tectonic and regional implications. Journal of Volcanology and Geothermal Research, 14(1-2), 67-75.

Bauluz, B., Gasca, J.M., Moreno-Azanza, M., Canudo, J.I., 2014. Unusual replacement of biogenic apatite by aluminium phosphate phases in dinosaur teeth from the Early Cretaceous of Spain. Lethaia, 47, 556-566.

Borruel-Abadía, V., Barrenechea, J.F., Galán-Abellán, A.B., Alonso-Azcárate, J., De la Horra, R., Luque, F.F, LópezGómez, J., 2016. Quantifying aluminium phosphate-sulphate minerals as markers of acidic conditions during the PermianTriassic transition in the Iberian Ranges, E Spain. Chemical Geology, 429, 10-20.

Borruel-Abadía, V., Barrenechea, J.F, Galán-Abellán, A.B., De la Horra, R., López-Gómez, J., Ronchi, A., Luque, FJ., AlonsoAzcárate, J., Marzo, M., 2019. Could acidity be the reason behind the Early Triassic biotic crisis on land? Chemical Geology, 515, 77-86.

Bourbonniere, R.A., Meyers, P.A., 1996. Sedimentary geolipid records of historical changes in the watersheds and productivities of Lakes Ontario and Erie. Limnology and Oceanography, 41, 352-359.

Boynton, W.V., 1984. Cosmochemistry of the rare earth elements: meteorite studies. Developments in geochemistry, Elsevier, 2, 63-114.

Coufal, P., Mejstříková, L., 1996. Unikátní barium-stronciová mineralizace na lokalitách DNT. Hnědé Uhlí, VUHU Most, 1(96), 41-50.

Dericquebourg, P., Person, A., Ségalen L., Pickford, M., Senut, B., Fagel, N., 2015. Environmental significance of Upper Miocene phosphorites at hominid sites in the Lukeino Formation (Tugen Hills, Kenya). Sedimentary Geology, 327, 43-54.

Dericquebourg, P., Person, A., Ségalen, L., Pickford, M., Senut, B., Fagel, N., 2019. Bone diagenesis and origin of calcium phosphate nodules from a hominid site in the Lukeino Formation (Tugen Hills, Kenya). Palaeogeography, Palaeoclimatology, Palaeoecology, 536, 1-12.

Didyk, B.M., Simoneit, B.R.T., Brassell, S.C., Eglinton, G., 1978. Organic geochemical indicators of palaeoenvironmental conditions of sedimentation. Nature, 272, 216-222.

Dill, H.G., 2001. The geology of aluminium phosphates and sulphates of the alunite group minerals: a review. EarthScience Reviews, Elsevier, 53, 35-93.

Elderfield, H., Pagett, R., 1986. REE in ichthyoliths: variations with redox conditions and depositional environment. Science of Total Environment, 49, 175-197.

Evans-White, M., Stelzer, R.S., Lamberti, G.A., 2005. Taxonomic and regional patterns in benthic macroinvertebrate elemental composition in streams. Freshwater Biology, 11, 1786-1799.

Fernando, H.J.S., 1991. Turbulent mixing in stratified fluids. Annual Review of Fluid Mechanics, 23, 455-493.

Gladstone, Ch., McClelland, H.L.O., Woodcock, N.H., Hunt, J.E., 2018. The formation of convolute lamination in mud-rich turbidites. Sedimentology, 65, 1800-1825.

Haskin, M.A., Haskin, L.A., 1966. Rare earths in European shales: a redetermination. Science, 154, 507-509.
Havelcová, M., Sýkorová, I., Mach, K., Trejtnarová, H., Blažek, J., 2015. Petrology and organic geochemistry of the lower Miocene lacustrine sediments (Most Basin, Eger Graben, Czech Republic). International Journal of Coal Geology, 139, 26-39.

Hecky, R.E., Campbell, P., Hendzel, L.L., 1993. The stoichiometry of carbon, nitrogen, and phosphorus in particulate matter of lakes and oceans. Limnology and Oceanography, 38(4), 709-724.

Heifetz, E., Agnon, A., Marco, S., 2005. Soft sediment deformation by Kelvin Helmholtz Instability: A case from Dead Sea earthquakes. Earth and Planetary Science Letters, 236, 497-504.

Hessen, D.O., Andersen, T., 1990. Bacteria as a source of phosphorous for zooplankton. Hydrobiologia, 206, 217-223.

Holbourn, A., Kuhnt, W., Kochhann, K.G.D., Andersen, N., Meier, K.J.S., 2015. Global perturbation of the carbon cycle at the onset of the Miocene Climatic Optimum. Geology, 43, 123-126.

Holub, FV., Rapprich, V., Erban, V., Pécskay, Z., Mlčoch, B., Míková, J., 2010. Petrology and geochemistry of the Tertiary alkaline intrusive rocks at Doupov, Doupovské hory Volcanic Complex (NW Bohemian Massif). Journal of Geosciences, 55(3), 251-278.

Hora, J.M., Singer, B.S., Jicha, B.R., Beard, B.L., Johnson, C.M., de Silva, S., Salisbury, M., 2010. Volcanic biotite-sanidine 40Ar/39Ar age discordances reflect Ar partitioning and preeruption closure in biotite. Geology, 38(10), 923-926.

Huang, W.H., Keller, W.D., 1972. Geochemical mechanics for the dissolution, transport, and deposition of aluminium in the zone of weathering. Clays and Clay Minerals, 20, 69-74.

Jochum, P., Hohl, U., Herwig, K., Lammel, E., Stoll, B., Hofmann, A.W., 2005. GeoReM: A New Geochemical Database for Reference Materials and Isotopic Standards. Geostandards and Geoanalytical Research, 29(3), 333-338.

Kasinski, J., 1991 Tertiary lignite-bearing lacustrine facies of the Zittau Basin: Ohre rift system (Poland, Germany and Czechoslovaquia). International association of Sedimentology, 13 (Special Publications), 93-107.

Kempe, U., Bombach, K., Matukov, D., Schlothauer, T., Hutschenreuter, J., Wolf, D., Sergeev, S., 2004. $\mathrm{Pb} / \mathrm{Pb}$ and U/ $\mathrm{Pb}$ zircon dating of subvolcanic rhyolite as a time marker for Hercynian granite magmatism and $\mathrm{Sn}$ mineralization in the Eibenstock granite, Erzgebirge, Germany: considering effects of zircon alteration. Mineralium Deposita, 39, 646-669.

Kokowska-Pawlowska, M., Nowak, J., 2013. Phosphorus minerals in tonstein; coal seam 405 at Sośnica-Makoszowy coal mine, Upper Silesia, southern Poland. Acta Geologica Polonica, 63(2), 271-281.

Kedzierski, M., Uchman, A., Sawlowicz, Z., Briguglio, A., 2015. Fossilized bioelectric wire - the trace fossil Trichichnus. Biogeosciences, 12, 2301-2309.

Kříbek, B., Knésl, I., Rojík, P., Sýkorová, I., Martínek, K., 2017. Geochemical history of a Lower Miocene lake, the Cypris Formation, Sokolov Basin, Czech Republic. Journal of Paleolimnology, 58, 169-190. 
Lieth, H., Whittaker, R.H. (eds.), 1975. Primary Productivity of the Biosphere. Ecological studies, Analysis and synthesis, Springer-Verlag New York Inc., 14, 339pp.

Lippolt, H.J., 1983. Distribution of volcanic activity in space and time. In: Fuchs, K. (ed.). Plateau uplift. Springer, 112-120.

Mach, K., 1997. A logging correlation scheme for the Main coal seam of the North Bohemian brown coal basin, and the implications for the palaeogeographical development of the basin. European Coal Geology and Technology, Geological Society, 125 (Special Publications), 309-320.

Mach, K., Žák, K., Jačková, I., 1999. Sulphur speciation and isotopic composition in a vertical profile of the main coal seam of the North Bohemian Brown Coal basin and their paleogeographic interpretation. Bulletin of the Czech Geological Survey, 74(1), 51-66.

Mach, K., Žák, K., Jačková, I., 2001. Stable Isotope study of diagenetic carbonates in Miocene sediments of the North Bohemian Brown Coal Basin ("Most Basin"), Czech Republic. Abstracts of the 9th Coal Geology Conference Prague, 23.

Mach, K., Teodoridis, V., Matys Grygar, T., Kvaček, Z., Suhr, P., Standke, G., 2014. An evaluation of paleogeography and paleoecology in the Most Basin (Czech Republic) and Saxony (Germany) from the late Oligocene to the early Miocene. Neues Jahrbuch für Geologie und Paläontologie, Abhandlungen, 272(1), 13-45.

Matys Grygar, T., Mach, K., 2013a. Regional chemostratigraphic key horizons in the macrofossil-barren siliciclastic lower Miocene lacustrine sediments (Most Basin, Eger Graben, Czech Republic). Bulletin of Geosciences, 88(3), 557-571.

Matys Grygar, T., Mach, K., 2013b. Chemostratigraphy of Miocene sediments in Most Basin. Zprávy o geologických výzkumech $\mathrm{v}$ roce 2012. A regionální geologie a stratigrafie, 26-29.

Matys Grygar, T., Mach, K., Schnabl, P., Pruner, P., Laurin, J., Martinez, M., 2014. A lacustrine record of the early stage of the Miocene Climatic Optimum in Central Europe from the Most Basin, Ohře (Eger) Graben Czech Republic. Geological Magazine, 151(6), 1013-1033.

Matys Grygar, T., Hošek, M., Mach, K., Schnabl, P., Martinez, M., 2017. Climatic instability before the Miocene Climatic Optimum reflected in a Central European lacustrine record from the Most Basin in the Czech Republic. Palaeogeography, Palaeoclimatology, Palaeoecology, 485, 930-945.

Matys Grygar, T., Mach, K., Martinez, M., 2019a. Checklist for the use of potassium concentrations in siliciclastic sediments as paleoenvironmental archives. Sedimentary Geology, 382, 75-84.

Matys Grygar, T., Mach, K., Schnabl, P., Martinez, M., Zeeden, C., 2019b. Orbital forcing and abrupt events in a continental weathering proxy from central Europe (Most Basin, Czech Republic, 17.7-15.9 Ma) recorded beginning of the Miocene Climatic Optimum. Palaeogeography, Palaeoclimatology, Palaeoecology, 514, 423-440.

Matys Grygar, T., Mach, M. Koubová, P., Martinez, M., Hron, K., Fačevicová, K., 2021. Beginning of the Miocene Climatic Optimum in Central Europe in sediment archive of he Most Basin, Czech Republic. Bulletin of Geosciences, 96, 61-81.
May, I., Schnepfe, M.M., Naeser, C.R., 1963. Strontium Sorption Studies on Crandallite. Contributions to Geochemistry, Geological survey Bulletin, United States Printing Office, Washington, 1144-C, 1-17.

McArthur, J.M., Howarth, R.W., Bailey, T.R., 2001. Strontium isotope stratigraphy: LOWESS Version 3: Best fit to the marine Sr-isotope curve for 0-509 $\mathrm{Ma}$ and accompanying look-up table for deriving numerical age. The Journal of Geology, 109, 155-170.

McArthur, J.M., Howarth, G.A., Shields, G.A., 2012. Strontium Isotope Stratigraphy. In: Gradstein, FM., Ogg, J.G., Schmitz., Ogg, G. (eds.). The Geologic Time Scale. Elsevier, 127-144.

McKelvey, V.E., 1967. Phosphate Deposits. Contributions to economic geology. Geological Survey Bulletin, 1252-D, 21pp.

McIntyre, P.B., Flecker, A.S., 2010. Ecological Stoichiometry as an Integrative Framework in Stream Fish Ecology. American Fisheries Society Symposium, American Fisheries Society, 73, 539-558.

Mikuláš, R., Mach, K., Dvořák, Z., 2006. Bioturbation of Claystones of the Most Basin in the Bílina Quarry (Miocene, Czech Republic). Acta Universitatis Carolinae Geologica, 2003, 47(1-4), 79-85.

Muszyński, M., Wyszomirski, P., 1998. New occurrences of the crandallite group minerals in sedimentary rocks of Poland. Mineralogia Polonica, 29(1), 19-27.

Nádaskay, R., Kochergina, Y.V., Čech, S., Švábenická, L., Valečka, J., Erban, V., Halodová, P., Čejková, B., 2019. Integrated stratigraphy of an offshore succession influenced by intense siliciclastic supply: Implications for Coniacian tectonosedimentary evolution of the West Sudetic area (NW Bohemian Cretaceous Basin, Czech Republic). Cretaceous Research, 102, 127-159.

Novák, F., Pekárková, R., Ševců, J., 1993. Barium rich crandallite from the Nástup Tušimice quarry (North Bohemian Brown Coal Basin). Věstník českého geologického ústavu, 68(2), 53-57.

Novotný, T., Mach, K., 2017. Jsou v hlavní sloji mostecké pánve zachovány vulkanogenní proplástky (tzv. tonsteiny)? Zpravodaj Hnědé uhlí, VUHU Most, 2, 25-36.

Pécskay, Z., Lexa, J., Szakács, A., Seghedi, I., Balogh, K., Konečný, V., Zelenka, T., Kovacs, M., Póka, T., Fülöp, A., Márton, E., Panaiotu, C., Cvetković, V., 2006. Geochronology of Neogene magmatism in the Carpathian arc and intra-Carpathian area. Geologica Carpathica, 57(6), 511-530.

Pe-Piper, G., Dolansky, L.M., 2005. Early diagenetic origin of Al phosphate-sulfate minerals (woodhouseite and crandallite series) in terrestrial sandstones, Nova Scotia, Canada. American Mineralogist, 90, 1434-1441.

Rajchl, M., Uličný, D., Grygar, R., Mach, K., 2009. Evolution of basin architecture in an incipient continental rift: the Cenozoic Most Basin Eger Graben (Central Europe). Basin Research, 21, 269-294.

Rampino, M.R., Self, S., 1992. Volcanic winter and accelerated glaciation following the Toba super-eruption. Nature, 359(6390), 50-52. 
Rapprich, V., Cajz, V., Košták, M., Pécskay, Z., Řídkošil, T., Raška, P., Radoň, M., 2007. Reconstruction of eroded monogenic Strombolian cones of Miocene age: A case study on character of volcanic activity of the Jicin Volcanic Field (NE Bohemia) and subsequent erosional rates estimation. Journal of Geosciences, 52(3-4), 169-180.

Rapprich, V., Holub, FV., 2008. Geochemical variations within the Upper Oligocene-Lower Miocene lava succession of Úhošt' Hill (NE margin of Doupovské hory Mts., Czech Republic). Geological Quarterly, 52(3), 253-268.

Roetzel, R., de Leeuw, A., Mandic, O., Márton, E., Nehyba, S., Kuiper, K.F,, Scholger, R., Wimmer-Frey, I., 2014. Lower Miocene (Upper Burdigalian, Karpatian) volcanic ashfall at the south-eastern margin of the Bohemian Massif in Austria - New evidence from ${ }^{40} \mathrm{Ar} /{ }^{39} \mathrm{Ar}$-dating, paleomagnetic, geochemical and mineralogical investigations. Austrian Journal of Earth Sciences, 107(2), 2-22.

Rojík, P., 2004. New stratigraphic subdivision of the Tertiary in the Sokolov Basin in Northwestern Bohemia. Journal of the Czech Geological Society, 49(3-4), 173-184.

Rosenbaum, J., Sheppard, S.M.F., 1986. An isotopic study of siderites, dolomites and ankerites at high-temperatures. Geochimica et Cosmochimica Acta, 50(6), 1147-1150.

Spell, T.L., Harrison, T.M., 1993. 40Ar/39Ar geochronology of post-Valles Caldera rhyolites, Jemez Volcanic Field, New Mexico. Journal of Geophysical Research (Solid Earth), 98, 8031-8051.

Spötl, C., 1990. Authigenic aluminium phosphate-sulphates in sandstones of the Mitterberg Formation, Northern Calcareous Alps, Austria. Sedimentology, 37, 837-845.

Steiger, R.H., Jäger, E., 1977. Subcommission on Geochronology; convention on the use of decay constants in geo and cosmochronology. Earth and Planetary Science Letters, 36, 359-362.

Štemprok, M., 2016. Drill hole CS-1 penetrating the Cínovec/ Zinnwald granite cupola (Czech Republic): an A-type granite with important hydrothermal mineralization. Journal of Geosciences, 61(4), 395-423.

Szakács, A., Szakács, A., Márton, E., Póka, T., Zelenka, T., Pécskay, Z., Seghedi, I., 1998. Miocene acidic explosive volcanism in the Bukk Foreland, Hungary: identifying eruptive sequences and searching for source locations. Acta Geologica Hungarica, 41(4), 413-435.

ten Haven, H.L., de Leeuw, J.W., Rullkötter, J., Sinninghe Damsté, J.S., 1987. Restricted utility of the pristane/phytane ratio as a palaeoenvironmental indicator. Nature, 330, 641-643.
Triplehorn, D.M., Bohor, B.F., 1983. Goyazite in kaolinic altered tuff beds of Creataceous age near Denver, Colorado. Clays and Clay Minerals, 31(4), 299-304.

Ulrych, J., Svobodová, J., Balogh, K., 2002. The source of Cenozoic volcanism in the České středohoří Mts., Bohemian Massif. Neues Jahrbuch für Mineralogie, Abhandlungen, 177(2), 133-162.

Ulrych, J., Dostal, J., Adamovič, J., Jelínek, E., Špaček, P., Hegner, E., Balogh, K., 2011. Recurrent Cenozoic volcanic activity in the Bohemian Massif (Czech Republic). Lithos, 123, 133-144.

Veizer, J., 1993. Anthropogenic/Geogene dynamics of the Danube and the Elbe: Carbon and Strontium isotopes. Boston (MA, U.S.A.), GSA Annual Meeting, GSA Abstracts with Programs, A415.

Vieillard, P., Tardy, Y., Nahon, D., 1979. Stability fields of clays and aluminium phosphates: paragenesis in lateritic weathering of argillaceous phosphatic sediments. American Mineralogist, 64, 626-634.

Volkman, J.K., Johns, R.B., Gillan, FT., Perry, G.J., Bavor Jr., H.J., 1980. Microbial lipids of an intertidal sediment, I. Fatty acids and hydrocarbons. Geochimica et Cosmochimica Acta, 44, 1133-1143.

Walther, D., Breitkreuz, Ch., Rapprich, V., Kochergina, Y.V., Chlupáčová, M., Lapp, M., Stanek, K., Magna, T., 2016. The Late Carboniferous Schönfeld-Altenberg Depression on the NW margin of the Bohemian Massif (Germany/Czech Republic): volcanosedimentary and magmatic evolution. Journal of Geosciences, 61, 371-393.

Wright, J., Schrader, H., Holserab, W.T., 1987. Paleoredox variations in ancient oceans recorded by rare earth elements in fossil apatite. Geochimica et Cosmochimica Acta, 51, 631-644.

Zagorac, D., Müller, H., Ruehl, S., Zagorac, J., Rehme, S.J., 2019. Recent developments in the Inorganic Crystal Structure Database: theoretical crystal structure data and related features. Journal of Applied Crystallography, 52, 918-925.

Žák, K., 2007. Souhrnné zpracování geochemických dat z karbonátových konkrecí a pevných karbonátových poloh v lomu Bílina. Bílina (Severočeské doly, a.s.), Unpublished report, $80 \mathrm{pp}$.

Zelenka, T., Balázs, E., Balogh, K., Kiss, J., Kozák, M., Nemesi, L., Pécskay, Z., Püspöki, Z., Ravasz, C., Szeky-Fux, V., Újfalussy, A., 2004. Buried Neogene volcanic structures in Hungary. Acta Geologica Hungarica, 47(2-3), 177-219.

Zieliński, M., Dopieralska, J., Belka, Z., Walczak, A., Siepak, M., Jakubowicz, M., 2018. Strontium isotope identification of water mixing sources in a river system (Oder River, central Europe): A guantitative aproach. Hydrological Processes, 1-15.

Manuscript received August 2020;

revision accepted July 2021;

published Online September 2021. 


\section{APPENDIX I}

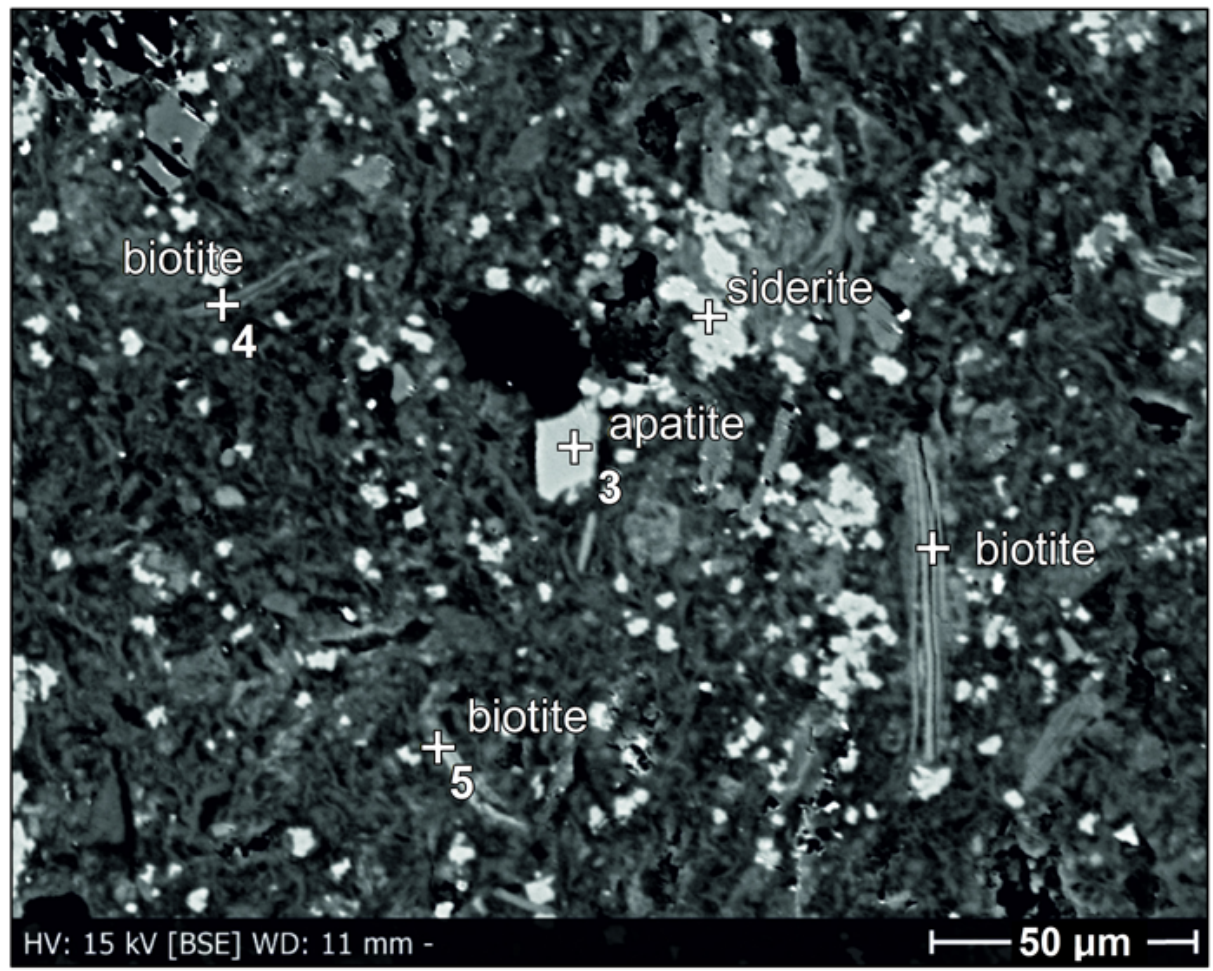

FIGURE I. Electron microprobe M1a. For details see Table IV.

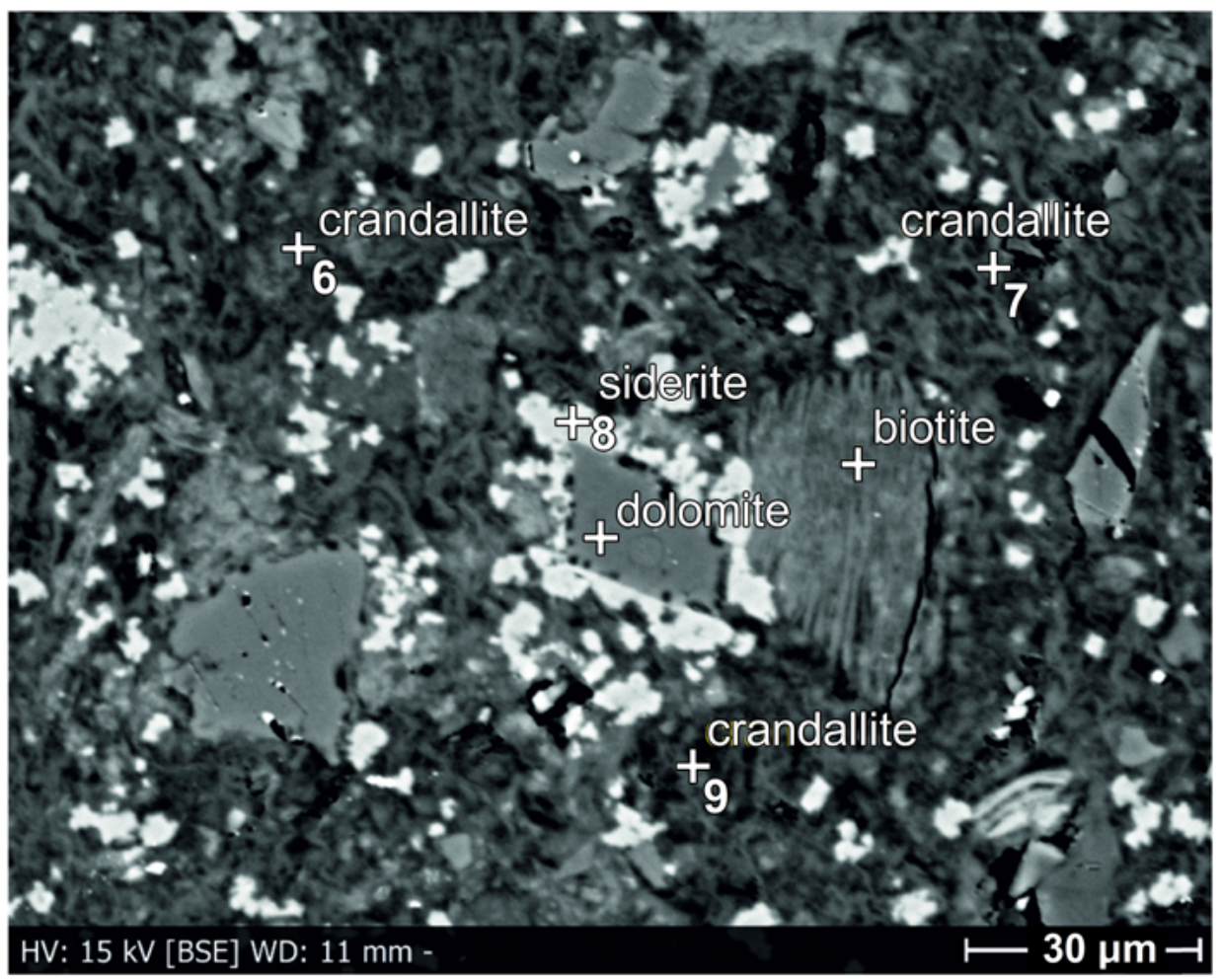

FIGURE II. Electron microprobe M1b. For details see Table IV. 


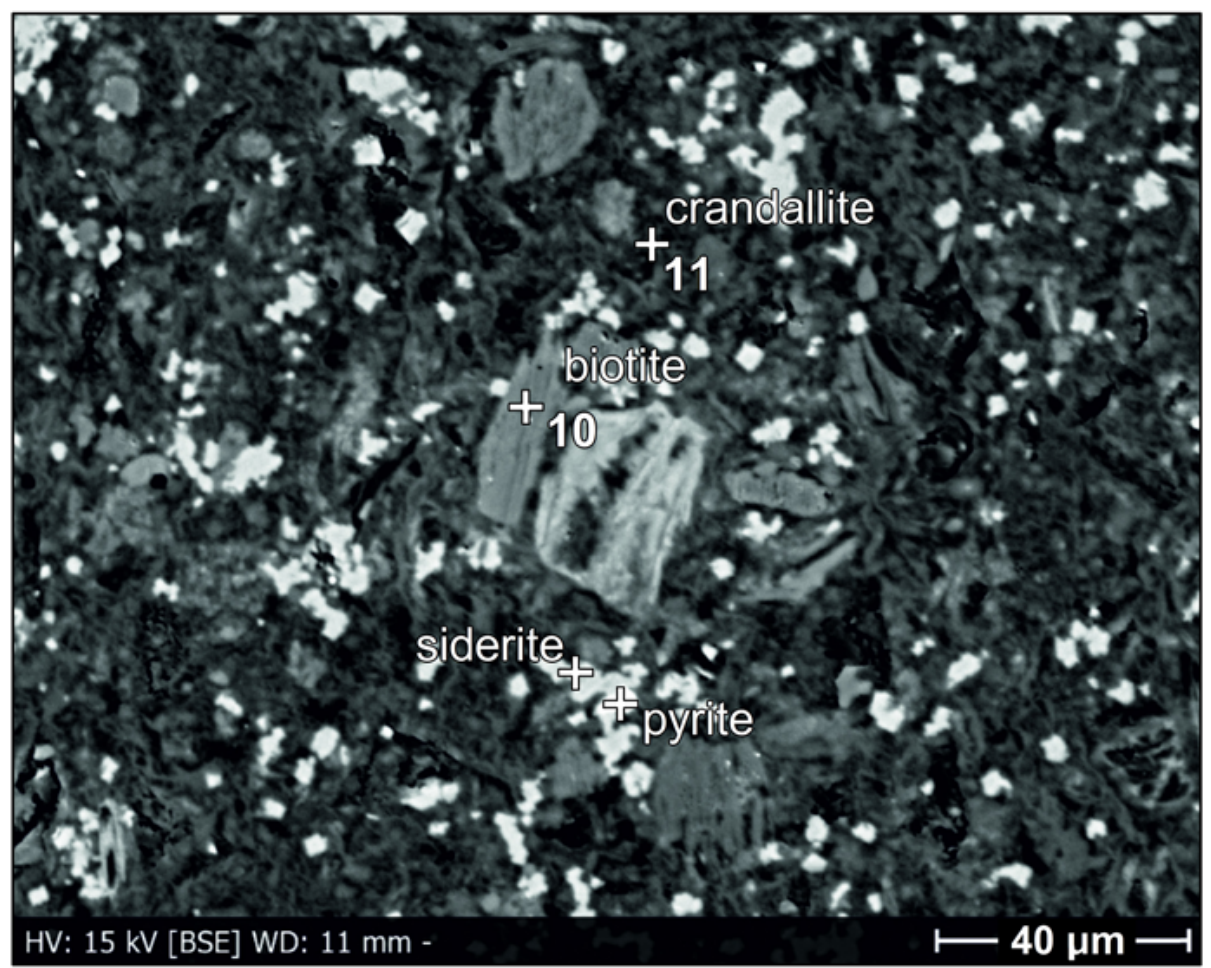

FIGURE III. Electron microprobe M1c. For details see Table IV.

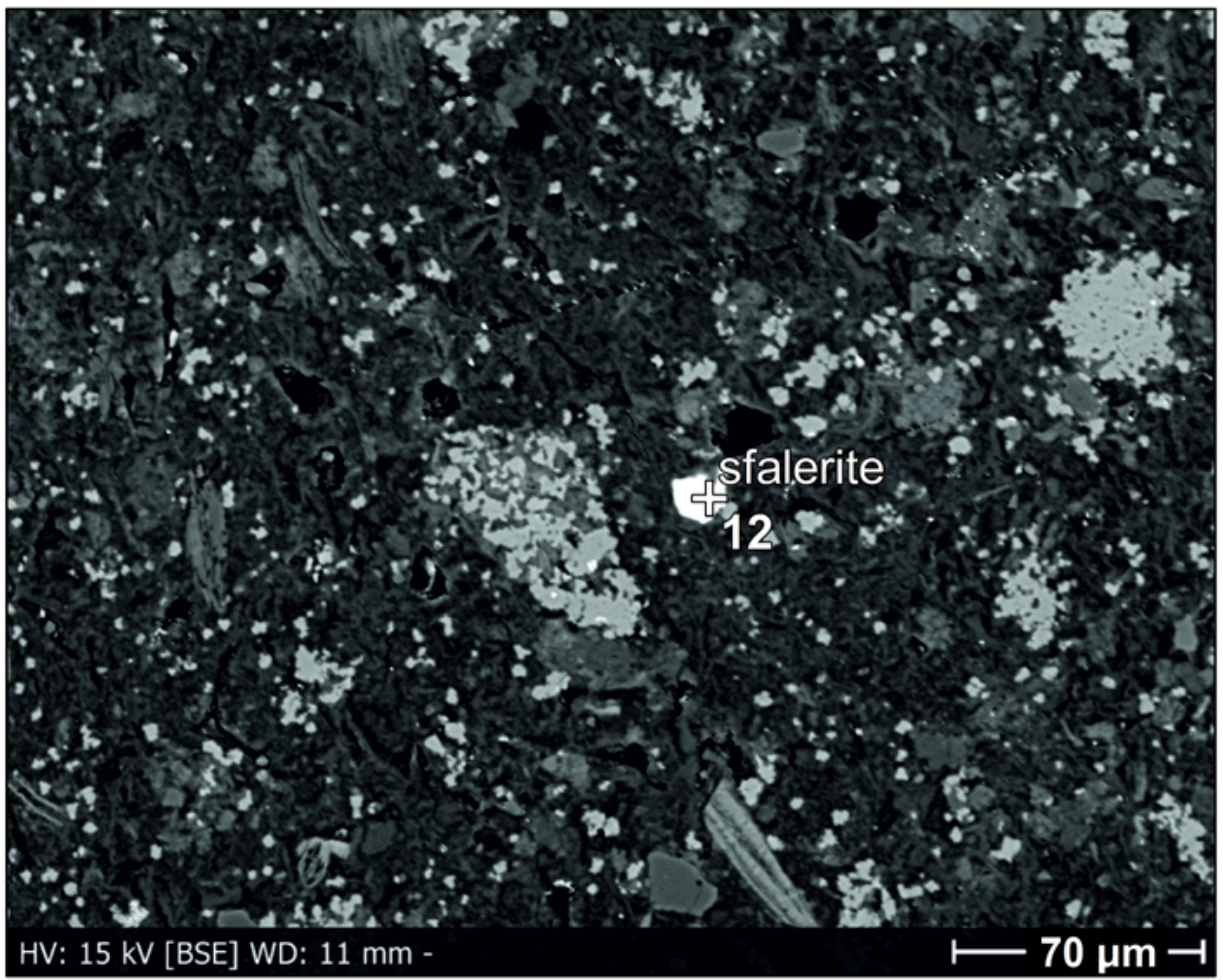

FIGURE IV. Electron microprobe M1d. For details see Table IV. 


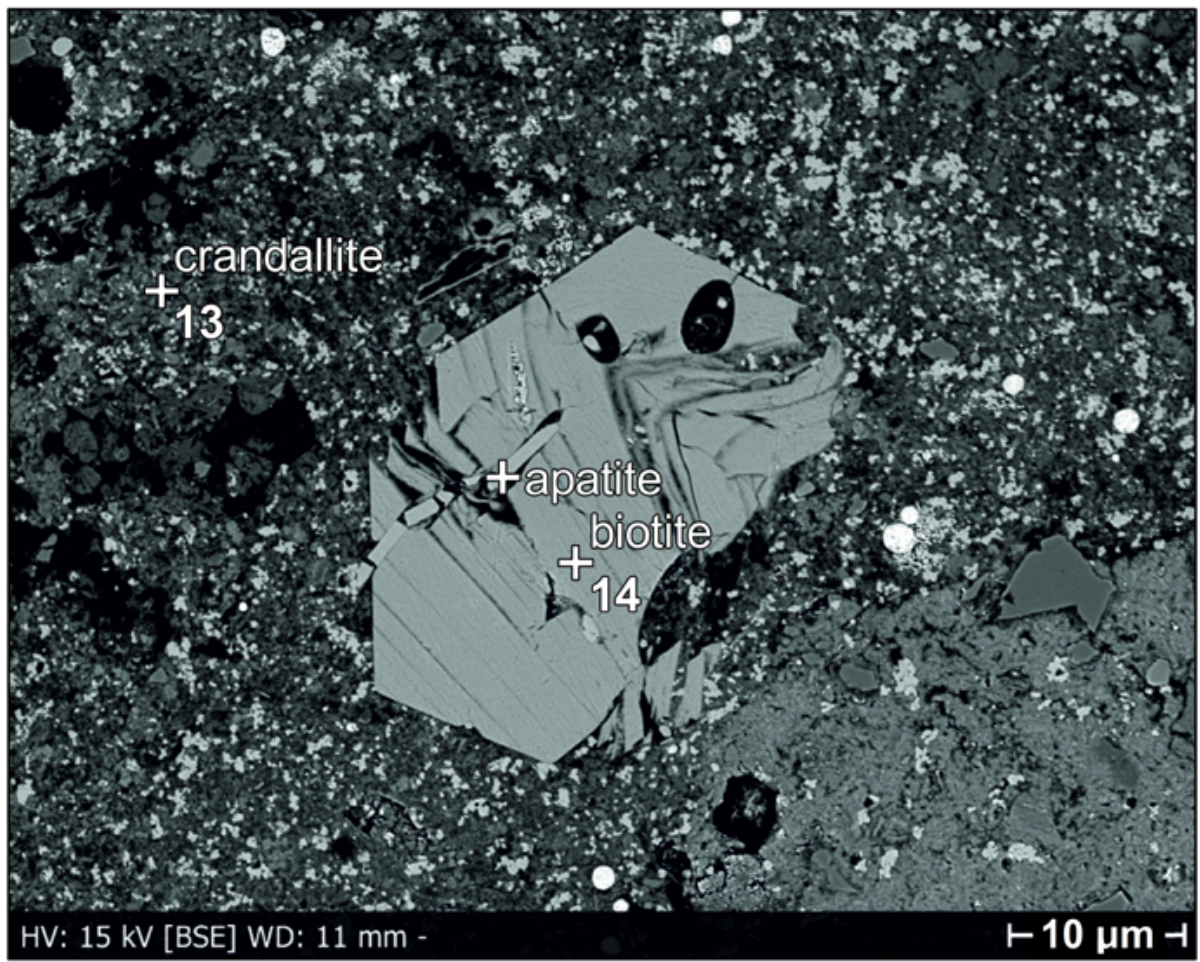

FIGURE V. Electron microprobe M2a. For details see Table IV.

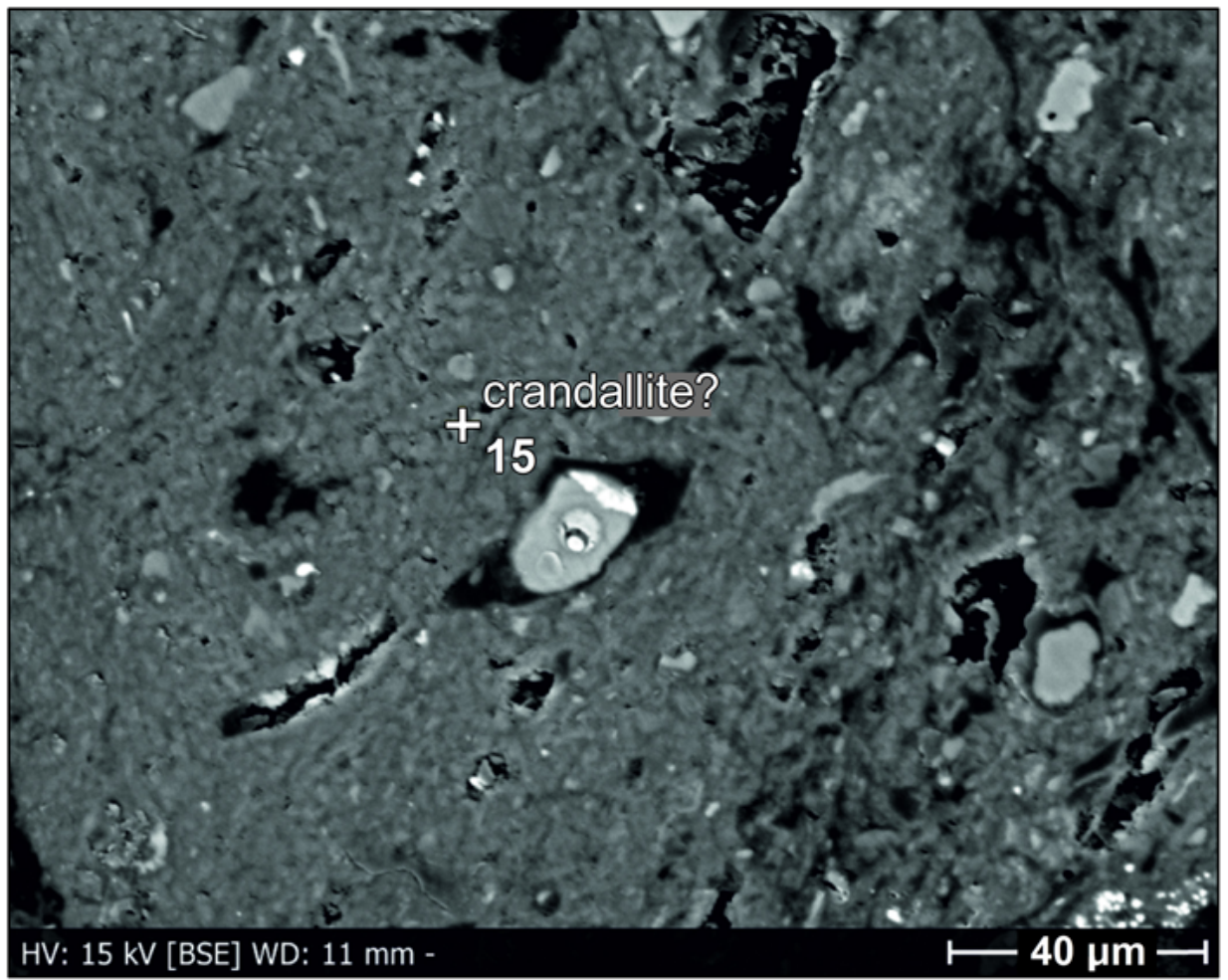

FIGURE VI. Electron microprobe M2b. For details see Table IV. 


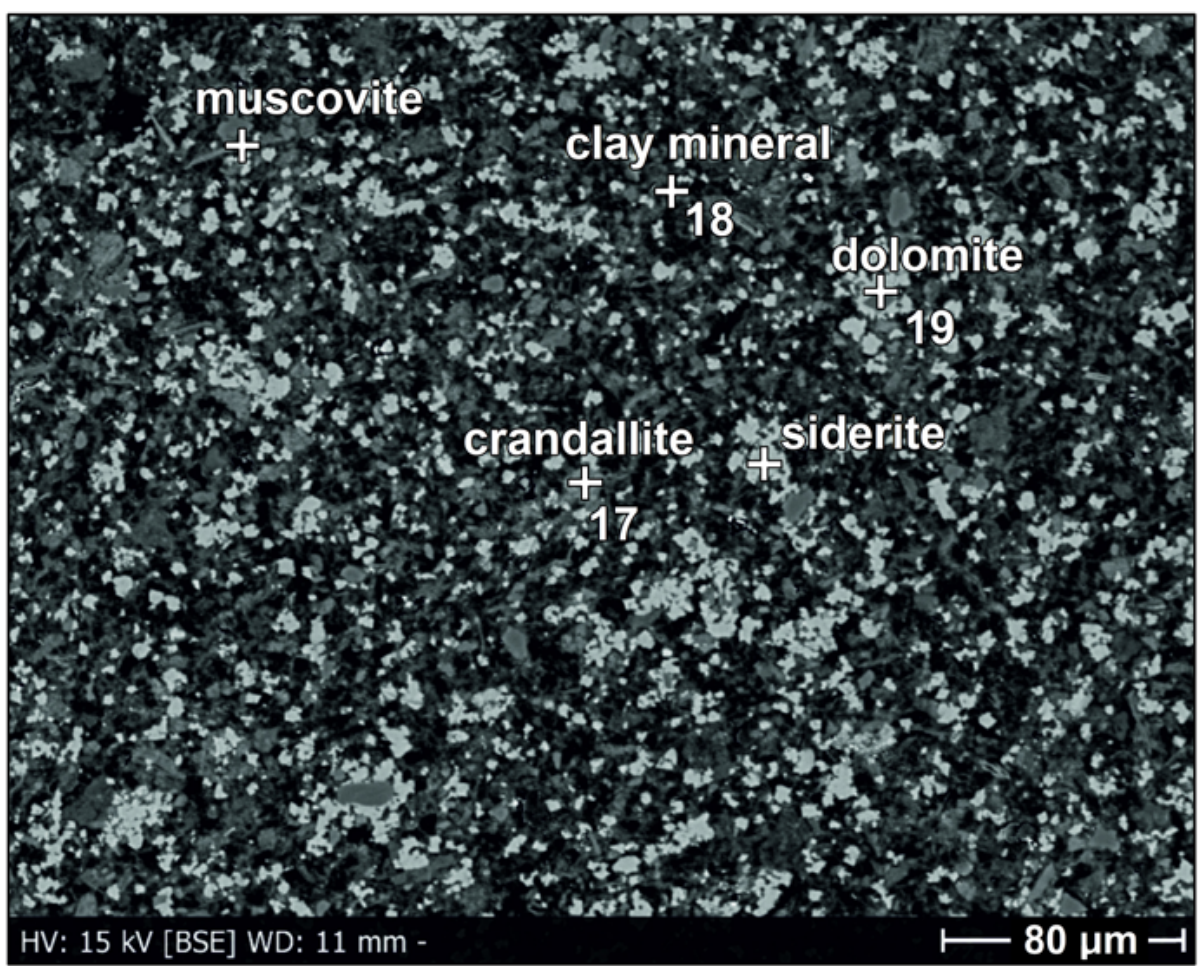

FIGURE VII. Electron microprobe M3. For details see Table IV.

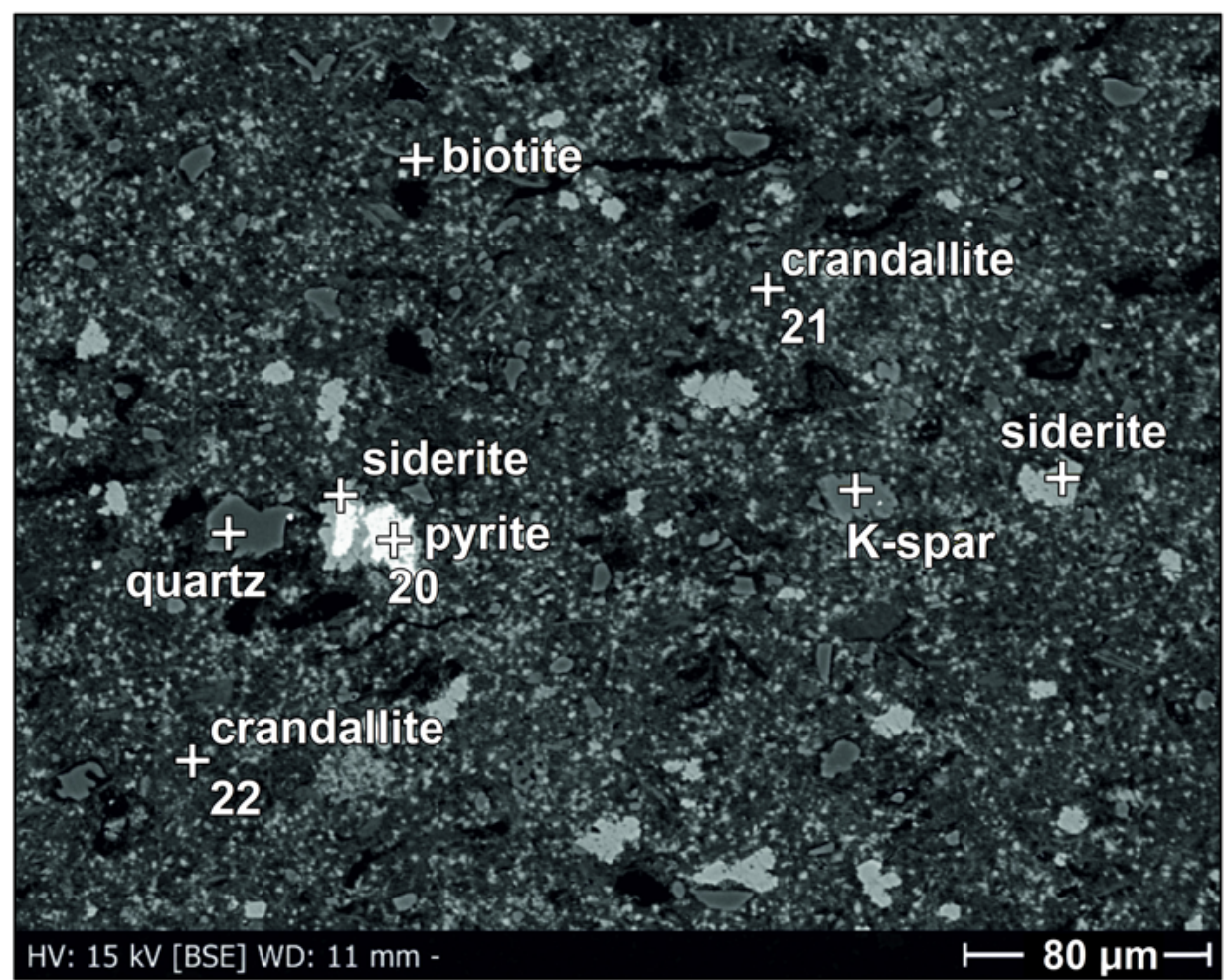

FIGURE VIII. Electron microprobe M4. For details see Table IV. 


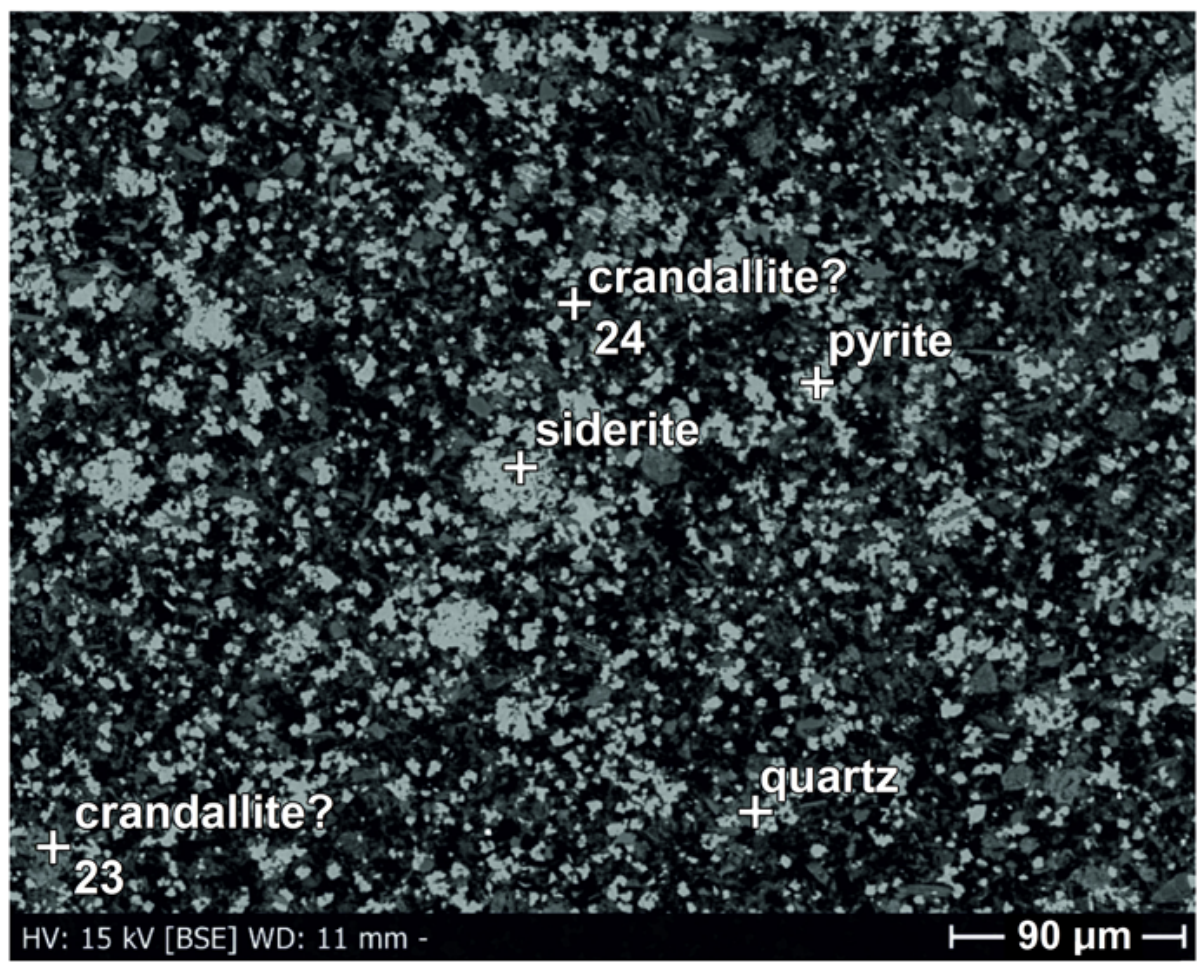

FIGURE IX. Electron microprobe M5. For details see Table IV.

TABLE I. Chemical composition of individual clasts, crystals or amorphous phase of C\# beds using a JEOL JXA-8600 electron microprobe. C1DNT samples. M1: basal sandy lamina, vertical section (perpendicular to the bottom contact), M2: basal sandy lamina, horizontal section (parallel to the bottom contact), M3: middle part of C1 with lower content of siderite, M4: upper part, section near the contact with overlying clay, M5: middle part of $\mathrm{C} 1$, higher content of siderite

\begin{tabular}{|c|c|c|c|c|c|c|c|c|c|}
\hline Sample & Description & Unit & Locality & $\mathrm{Sr}(\mathrm{ppm})$ & $\mathrm{Rb}(\mathrm{ppm})$ & $\mathrm{Sr} / \mathrm{Rb}$ & $\begin{array}{l}{ }^{87} \mathrm{Sr} /{ }^{86} \mathrm{Sr} \\
\text { measured }\end{array}$ & $2 \sigma$ & ${ }^{87} \mathrm{Sr}^{86} \mathrm{Sr}_{17}$ \\
\hline C1DBA (Cr01c) & C1 bed - upper part & Libkovice M. & Bílina Mine & 13225 & 21 & 634 & 0,709738 & 0,000010 & 0,709737 \\
\hline C1DBB (Cr01t) & $\mathrm{C} 1$ bed - basal lamina & Libkovice M. & Bílina Mine & 2317 & 61 & 38 & 0,709932 & 0,000013 & 0,709914 \\
\hline C2DBA (Cr02c) & $\mathrm{C} 2$ bed - upper part & Libkovice M. & Bílina Mine & 15640 & 13 & 1237 & 0,709885 & 0,000042 & 0,709884 \\
\hline C2DBB (Cr02t) & $\mathrm{C} 2$ bed - basal lamina & Libkovice M. & Bílina Mine & 3118 & 47 & 66 & 0,709937 & 0,000011 & 0,709926 \\
\hline C3DBA (Cr03a) & C3 bed - upper half & Libkovice M. & Bílina Mine & 13795 & 15 & 908 & 0,710192 & 0,000010 & 0,710191 \\
\hline C3DBB (Cr03b) & C2 bed - lower half & Libkovice M. & Bílina Mine & 14950 & 32 & 470 & 0,710223 & 0,000010 & 0,710222 \\
\hline SD 18/2019 & clay & Osek M. & OS17 drill hole & 50 & 60 & 1 & 0,724202 & 0,000008 & 0,723362 \\
\hline SD 19/2019 & clay & Lom M. & Bílina Mine & 60 & 50 & 1 & 0,728985 & 0,000009 & 0,728401 \\
\hline SD 20/2019 & clay & Lom M. & Bílina Mine & 60 & 50 & 1 & 0,728577 & 0,000008 & 0,727993 \\
\hline SD 10/2019 & clay & Libkovice M. & SP378 drill hole & 150 & 60 & 3 & 0,717065 & 0,000008 & 0,716785 \\
\hline SD 8/2019 & clay & Libkovice M. & Bílina Mine & 130 & 60 & 2 & 0,717969 & 0,000008 & 0,717646 \\
\hline SD 9/2019 & clay & Břešt'any clay & Bílina Mine & 105 & 65 & 2 & 0,721928 & 0,000010 & 0,721495 \\
\hline SD 11/2019 & clay & Břešt'any clay & Bílina Mine & 75 & 60 & 1 & 0,724621 & 0,000010 & 0,724061 \\
\hline SD 14/2019 & clay & Holešice M. & AL507 drill hole & 120 & 60 & 2 & 0,722326 & 0,000008 & 0,721976 \\
\hline SD 12/2019 & clay & Holešice M. & Bílina Mine & 85 & 75 & 1 & 0,723718 & 0,000007 & 0,723100 \\
\hline SD 13/2019 & clay & Holešice M. & SP378 drill hole & 250 & 60 & 4 & 0,715291 & 0,000010 & 0,715123 \\
\hline SD 6/2019 & limestone - cone-in-cone & Holešice M. & Bílina Mine & 50 & 20 & 3 & 0,718667 & 0,000009 & 0,718387 \\
\hline SD 7/2019 & limestone - concretion & Holešice M. & Libouš Mine & 125 & 30 & 4 & 0,712370 & 0,000010 & 0,712202 \\
\hline SD 21/2019 & clay breccia & Holešice M. & Libouš Mine & 1200 & 20 & 60 & 0,708605 & 0,000012 & 0,708593 \\
\hline SD 22/2019 & clay breccia & Holešice M. & Libouš Mine & 14600 & 25 & 584 & 0,709920 & 0,000009 & 0,709919 \\
\hline SD $1 / 2019$ & travertine & Duchcov M. & Merkur Mine & 700 & 30 & 23 & 0,716447 & 0,000008 & 0,716417 \\
\hline SD 2/2019 & travertine & Duchcov M. & Merkur Mine & 2000 & 2 & 1000 & 0,716008 & 0,000009 & 0,716007 \\
\hline Cr5 & hauyne tephrite & Střezov Formation. & Milá Hill & 717 & 41 & 17 & 0,703390 & 0,000011 & 0,703350 \\
\hline SD $3 / 2019$ & spongilite limestone & Upper Cretaceous & Nové Strašecí & 260 & 17 & 15 & 0,708928 & 0,000010 & 0,708882 \\
\hline SD 4/2019 & clayey limestone & Upper Cretaceous & Bílina Mine & 580 & 20 & 29 & 0,708665 & 0,000009 & 0,708641 \\
\hline SD $5 / 2019$ & spongilite limestone & Upper Cretaceous & Hrádek near Raná & 250 & 5 & 50 & 0,709548 & 0,000008 & 0,709534 \\
\hline
\end{tabular}


TABLE I. Continued

\begin{tabular}{|c|c|c|c|c|c|c|c|c|c|}
\hline Sample & Description & Unit & Locality & $\mathrm{Sr}(\mathrm{ppm})$ & $\mathrm{Rb}(\mathrm{ppm})$ & $\mathrm{Sr} / \mathrm{Rb}$ & $\begin{array}{l}{ }^{87} \mathrm{Sr} /{ }^{86} \mathrm{Sr} \\
\text { measured }\end{array}$ & $2 \sigma$ & ${ }^{87} \mathrm{Sr} /{ }^{86} \mathrm{Sr}_{17}$ \\
\hline SD $15 / 2019$ & biotite granite & Carboniferous & Fláje & 450 & 60 & 8 & 0,712959 & 0,000009 & 0,712866 \\
\hline FLG01 & biotite granite & Carboniferous & Fláje & 227 & 141 & 16 & 0,717260 & 0,000008 & 0,716826 \\
\hline SD $16 / 2019$ & rhyolite & Carboniferous & Dubí & 30 & 150 & 0 & 0,826417 & 0,000010 & 0,822883 \\
\hline TR25 & fiamme-rich rhyolite ignimbrite & Carboniferous & Divoká Bystřice gorge & 61 & 387 & 0 & 0,793843 & 0,000001 & 0,789377 \\
\hline Mi-4/391.7 & fiamme-rich rhyolite ignimbrite & Carboniferous & $\begin{array}{l}\text { Mikulov, road to Cinovec, } \\
\text { drilling Mi-4, depth } 391.7 \mathrm{~m}\end{array}$ & 17 & 324 & 0 & 0,928444 & 0,000001 & 0,914881 \\
\hline $\mathrm{Mi}-4 / 584.9$ & fiamme-rich rhyolite ignimbrite & Carboniferous & $\begin{array}{l}\text { Mikulov, road to Cínovec, } \\
\text { drilling Mi-4, depth } 584.9 \mathrm{~m}\end{array}$ & 46 & 395 & 0 & 0,812818 & 0,000001 & 0,806707 \\
\hline RCT-01 & fiamme-rich rhyolite ignimbrite & Carboniferous & Teichweg (Zinnwald, GE) & 52 & 274 & 0 & 0,767168 & 0,000001 & 0,763442 \\
\hline TR22 & crystall-rich rhyolite ignimbrite & Carboniferous & Pramenáč hill & 17 & 366 & 0 & 1,011820 & 0,000001 & 0,996245 \\
\hline RCLug-02 & crystall-rich rhyolite ignimbrite & Carboniferous & Lugstein (Zinnwlad, GE) & 28 & 328 & 0 & 0,871888 & 0,000001 & 0,996245 \\
\hline Mi-4/166.5 & crystall-rich rhyolite ignimbrite & Carboniferous & $\begin{array}{l}\text { Mikulov, road to Cinovec, } \\
\text { drilling Mi-4, depth } 166.5 \mathrm{~m}\end{array}$ & 17 & 461 & 0 & 0,995794 & 0,000001 & 0,976078 \\
\hline TR18 & crystall-rich rhyolite ignimbrite & Carboniferous & Vlči kámen rock & 23 & 321 & 0 & 0,898912 & 0,000001 & 0,888917 \\
\hline TR39 & crystall-rich rhyolite ignimbrite & Carboniferous & Medvědi vrch hill & 28 & 307 & 0 & 0,851304 & 0,000001 & 0,843479 \\
\hline TR36 & crystall-rich rhyolite ignimbrite & Carboniferous & Spáleniště hill & 80 & 164 & 0 & 0,742550 & 0,000001 & 0,741103 \\
\hline TR20 & crystall-poor rhyolite lava & Carboniferous & Lysá hora hill & 5 & 332 & 0 & 1,793945 & 0,000002 & 1,739087 \\
\hline WO_73.5 & granite porphyry & Carboniferous & Přitkov, 6133_WO drill hole & 70 & 286 & 0 & 0,763085 & 0,000001 & 0,760196 \\
\hline FT63 & granite porphyry & Carboniferous & Ultendorf (GE) & 90 & 213 & 0 & 0,743160 & 0,000001 & 0,741496 \\
\hline $231 / 1$ & Li-mica granite & Carboniferous & $\begin{array}{l}\text { Cínovec, drilling CS-1, } \\
\text { depth } 724.6\end{array}$ & 6 & 1194 & 0 & 3,532659 & 0,000003 & 3,349385 \\
\hline $231 / 2$ & Li-mica granite & Carboniferous & $\begin{array}{l}\text { Cinovec, drilling CS-1, } \\
\text { depth } 724.8\end{array}$ & 4 & 1093 & 0 & 2,178822 & 0,000001 & 1,945868 \\
\hline SD 25/2019 & gneiss argilized & Upper Proterozoic & ČSA Mine & 40 & 110 & 0 & 0,791857 & 0,000009 & 0,789920 \\
\hline SD $17 / 2019$ & elluvium of gneiss & Duchcov M. & ČSA Mine & 51 & 50 & 1 & 0,734252 & 0,000009 & 0,733565 \\
\hline SD 23/2019 & gneiss & Upper Proterozoic & KH mts. - Horní Jiřetín & 150 & 50 & 3 & 0,723300 & 0,000009 & 0,723067 \\
\hline SD 24/2019 & gneiss & Upper Proterozoic & KH mts. - Boleboř & 90 & 150 & 1 & 0,785664 & 0,000008 & 0,784490 \\
\hline SD 26/2019 & gneiss & Upper Proterozoic & KH mts. - Křimov & 100 & 170 & 1 & 0,730943 & 0,000009 & 0,729752 \\
\hline SD $27 / 2019$ & gneiss argilized & Upper Proterozoic & Merkur Mine & 500 & 40 & 13 & 0,720578 & 0,000007 & 0,720522 \\
\hline
\end{tabular}


TABLE II. Strontium isotope results

\begin{tabular}{|c|c|c|c|c|}
\hline $\begin{array}{c}\text { Sample / } \\
\text { Stratigraphy+E20A1:A1:E83 }\end{array}$ & $\begin{array}{l}\text { Locality / } \\
\text { Drillhole }\end{array}$ & $\begin{array}{c}\text { Position in the profile / } \\
\text { depth m }\end{array}$ & $\begin{array}{c}d^{13} \mathrm{C} \\
\text { (\%o } \\
\text { PDBV) }\end{array}$ & $\begin{array}{c}\mathrm{d}^{18} \mathrm{O} \\
(\% \mathrm{o} \\
\text { PDBV) }\end{array}$ \\
\hline C1DNTSA & Libouš North & top (hard) & $-3,17$ & $-5,80$ \\
\hline C1DNTSB & Libouš North & $2 \mathrm{~cm}$ from the top (hard) & $-3,13$ & $-5,86$ \\
\hline C1DNTSC & Libouš North & $5 \mathrm{~cm}$ from the top (hard) & $-3,09$ & $-5,96$ \\
\hline C1DNTSD & Libouš North & $8 \mathrm{~cm}$ from the top (soft) & $-2,57$ & $-5,93$ \\
\hline C1DNTSE & Libouš North & basal lamina with biotite & $-0,79$ & $-4,90$ \\
\hline C1DNTJA & Libouš South & top (hard) & $-2,40$ & $-5,58$ \\
\hline C1DNTJB & Libouš South & $2 \mathrm{~cm}$ from the top (hard) & $-2,38$ & $-5,56$ \\
\hline C1DNTJC & Libouš South & $5 \mathrm{~cm}$ from the top (soft) & $-1,95$ & $-5,52$ \\
\hline C1DNTJD & Libouš South & basal lamina with biotite & 1,10 & $-4,50$ \\
\hline Libkovice M. & LB297 & 32,50 & 8,52 & $-0,72$ \\
\hline Libkovice M. & LB297 & 41,83 & 10,46 & 0,02 \\
\hline Libkovice M. & LB297 & 49,50 & 7,48 & $-1,61$ \\
\hline Libkovice M. & LB297 & 52,50 & 3,59 & $-3,01$ \\
\hline Libkovice M. & LB297 & 52,50 & 3,57 & $-3,01$ \\
\hline Libkovice M. & LB297 & 59,17 & 2,78 & $-3,76$ \\
\hline Libkovice M. & LB297 & 63,17 & 1,52 & $-3,57$ \\
\hline Libkovice M. & LB297 & 63,87 & 4,73 & $-1,93$ \\
\hline Libkovice M. & LB297 & 67,17 & 1,27 & $-4,18$ \\
\hline Libkovice M. & LB297 & 67,17 & 1,27 & $-4,23$ \\
\hline Libkovice M. & LB297 & 70,87 & 7,46 & $-1,34$ \\
\hline Libkovice M. & LB297 & 73,18 & 1,42 & $-3,92$ \\
\hline Libkovice M. & LB297 & 76,83 & 4,11 & $-3,34$ \\
\hline Libkovice M. & LB297 & 80,50 & 6,78 & $-2,17$ \\
\hline Libkovice M. & LB297 & 81,50 & 4,44 & $-2,82$ \\
\hline Libkovice M. & LB297 & 85,17 & 4,92 & $-3,22$ \\
\hline Libkovice M. & LB297 & 98,50 & 4,78 & $-2,91$ \\
\hline Libkovice M. & LB297 & 102,17 & 0,26 & $-5,08$ \\
\hline Libkovice M. & LB297 & 102,25 & 2,28 & $-4,71$ \\
\hline Libkovice M. & LB297 & 110,83 & 1,97 & $-4,66$ \\
\hline Libkovice M. & LB297 & 115,83 & 2,69 & $-4,69$ \\
\hline Libkovice M. & LB297 & 117,50 & 1,22 & $-4,83$ \\
\hline Holešice M. & LB297 & 121,17 & 4,49 & $-4,17$ \\
\hline Holešice M. & LB297 & 121,50 & 0,32 & $-5,06$ \\
\hline Holešice M. & LB297 & 124,17 & 1,08 & $-4,39$ \\
\hline Holešice M. & LB297 & 126,50 & 0,21 & $-5,18$ \\
\hline Holešice M. & LB297 & 129,50 & 1,38 & $-4,54$ \\
\hline Holešice M. & LB297 & 129,50 & 1,43 & $-4,77$ \\
\hline Holešice M. & LB297 & 134,18 & 1,90 & $-4,45$ \\
\hline Holešice M. & LB297 & 141,83 & 5,48 & $-4,05$ \\
\hline Holešice M. & LB297 & 148,83 & 4,26 & $-6,27$ \\
\hline Holešice M. & LB297 & 153,50 & 5,29 & $-4,65$ \\
\hline Holešice M. & LB297 & 159,83 & 4,40 & $-6,17$ \\
\hline Holešice M. & LB297 & 164,50 & 3,72 & $-6,10$ \\
\hline Holešice M. & LB297 & 172,17 & 2,82 & $-6,16$ \\
\hline Holešice M. & LB297 & 181,90 & 3,51 & $-5,83$ \\
\hline Holešice M. & LB297 & 184,50 & 2,29 & $-4,36$ \\
\hline Holešice M. & LB297 & 193,50 & 2,01 & $-5,26$ \\
\hline Holešice M. & LB297 & 204,50 & $-1,27$ & $-6,11$ \\
\hline
\end{tabular}




\begin{tabular}{|c|c|c|c|c|}
\hline $\begin{array}{l}\text { Sample / } \\
\text { Stratigraphy+E20A1:A1:E83 }\end{array}$ & $\begin{array}{l}\text { Locality / } \\
\text { Drillhole }\end{array}$ & $\begin{array}{c}\text { Position in the profile / } \\
\text { depth } \mathrm{m}\end{array}$ & $\begin{array}{l}d^{13} \mathrm{C}(\% \circ \\
\text { PDBV) }\end{array}$ & $\begin{array}{l}d^{18} \mathrm{O}(\% \circ \\
\text { PDBV) }\end{array}$ \\
\hline Holešice $M$ & LB297 & 210,50 & 0,38 & $-4,49$ \\
\hline Holešice M. & LB297 & 213,50 & $-0,38$ & $-4,49$ \\
\hline Holešice M. & LB297 & 217,17 & 0,67 & $-4,43$ \\
\hline Holešice M. & LB297 & 222,50 & $-0,89$ & $-5,57$ \\
\hline Holešice M. & LB297 & 230,83 & $-0,28$ & $-4,67$ \\
\hline Holešice M. & LB297 & 236,17 & 2,07 & $-6,02$ \\
\hline Holešice M. & LB297 & 246,83 & $-3,32$ & $-6,02$ \\
\hline Holešice M. & LB297 & 286,05 & $-2,88$ & $-5,10$ \\
\hline Holešice M. & AL405 & 7,17 & 4,10 & $-3,63$ \\
\hline Holešice M. & AL405 & 13,83 & 2,36 & $-3,64$ \\
\hline Holešice M. & AL405 & 20,50 & 1,71 & $-3,85$ \\
\hline Holešice M. & AL405 & 29,50 & 1,75 & $-4,12$ \\
\hline Holešice M. & AL405 & 37,17 & 1,84 & $-4,43$ \\
\hline Holešice M. & AL405 & 48,82 & 3,16 & $-4,63$ \\
\hline Holešice M. & AL405 & 54,50 & 4,38 & $-3,05$ \\
\hline Libkovice M. & HK521 & 61,18 & 4,53 & $-4,18$ \\
\hline Libkovice M. & HK521 & 50,83 & 8,19 & $-0,49$ \\
\hline Libkovice M. & HK521 & 60,17 & 9,87 & 0,02 \\
\hline Libkovice M. & HK521 & 68,50 & 10,81 & 0,43 \\
\hline Libkovice M. & HK521 & 78,50 & 11,41 & 0,93 \\
\hline Libkovice M. & HK521 & 85,17 & 10,71 & 0,80 \\
\hline Libkovice M. & HK521 & 130,17 & 7,72 & $-0,73$ \\
\hline Libkovice M. & HK521 & 166,83 & 9,27 & $-0,80$ \\
\hline Libkovice M. & HK521 & 200,50 & 5,79 & $-1,85$ \\
\hline Holešice M. & HK521 & 241,83 & 11,81 & 0,12 \\
\hline Libkovice M. & SP257 & 32,50 & 7,49 & $-1,54$ \\
\hline Libkovice M. & SP257 & 37,17 & 8,62 & $-2,03$ \\
\hline Libkovice M. & SP257 & 41,83 & 8,56 & $-1,73$ \\
\hline Libkovice M. & SP257 & 45,83 & 9,21 & $-1,04$ \\
\hline Libkovice M. & SP257 & 49,17 & $-0,37$ & $-4,83$ \\
\hline Libkovice M. & SP257 & 54,17 & 7,01 & $-2,38$ \\
\hline Libkovice M. & SP257 & 64,50 & 9,10 & $-1,54$ \\
\hline Libkovice M. & SP257 & 71,50 & 7,64 & $-2,03$ \\
\hline Libkovice M. & SP257 & 80,50 & 8,28 & $-1,55$ \\
\hline Holešice M. & SP257 & 88,49 & 7,43 & $-2,12$ \\
\hline Holešice M. & SP257 & 106,50 & 7,95 & $-3,12$ \\
\hline Holešice M. & SP257 & 114,82 & 14,06 & $-1,86$ \\
\hline Holešice M. & SP257 & 152,17 & 3,92 & $-8,42$ \\
\hline
\end{tabular}




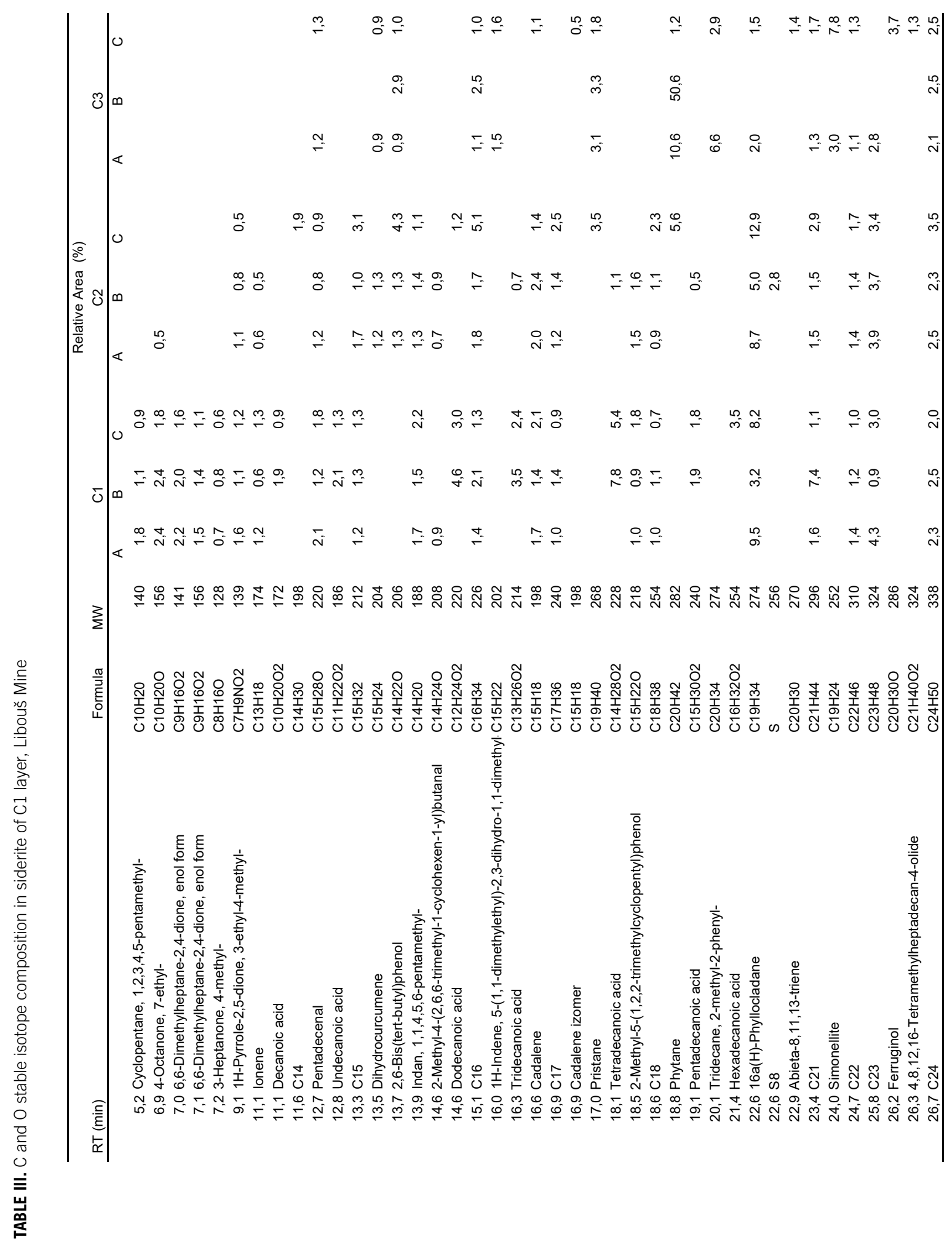




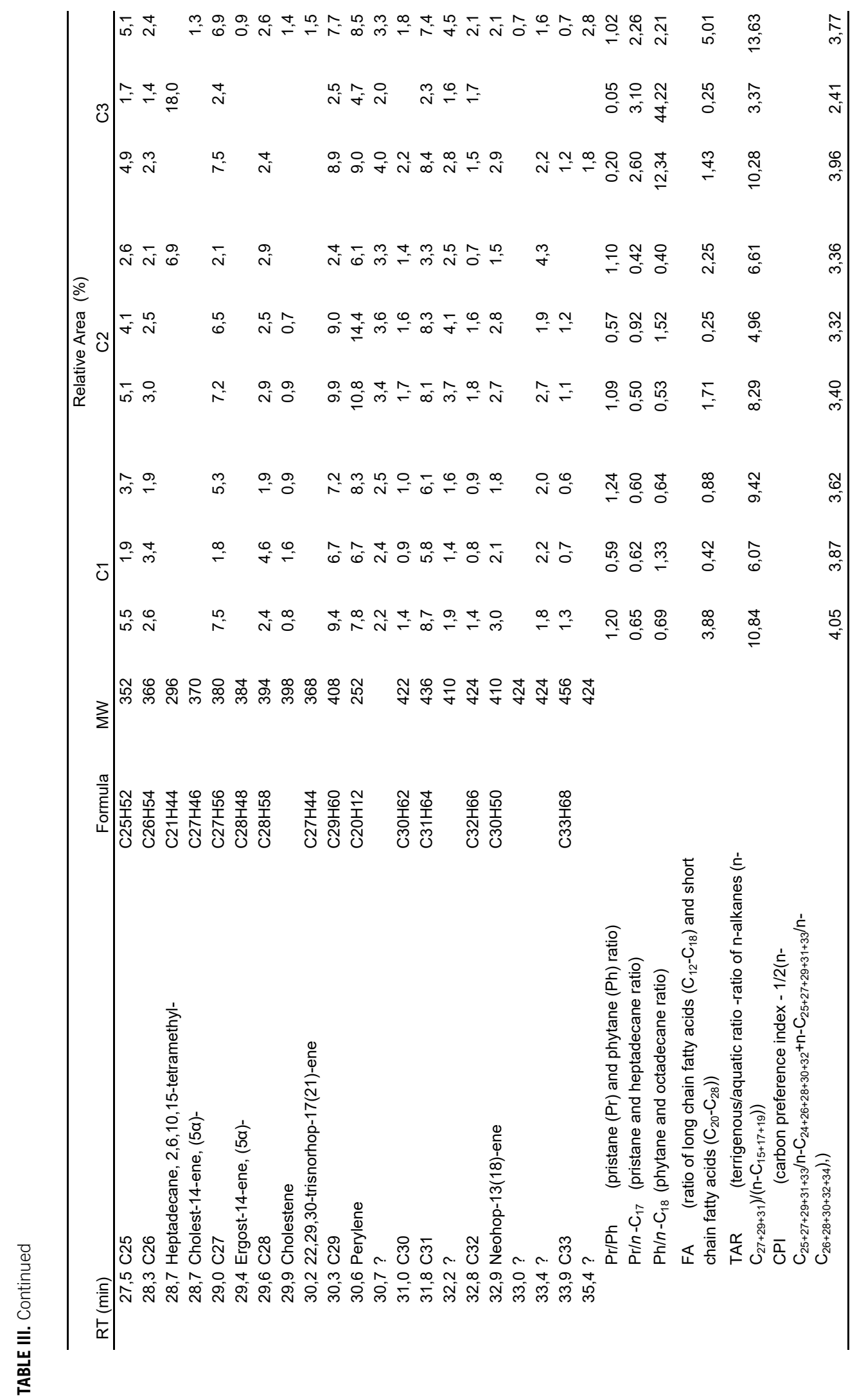


TABLE IV. Extractable organic matter composition of C\# beds and surrounding clays. Column A belongs to close overburden clay, column B represents the phosphate $\mathrm{C \#}$ bed, column $\mathrm{C}$ belongs to close underlying clay bed

\begin{tabular}{|c|c|c|c|c|c|c|c|c|c|c|}
\hline №/mineral & Elt & W\% & interval(95\%) & $\mathrm{A} \%$ & Ix/lstd & Kratio & Z.A.F. & coefs & $\mathrm{Ox} \%$ & Cat\# \\
\hline M1a-3 & $\mathrm{O}$ & 34,25 & 61,62 & 0 & 0 & & & & & \\
\hline \multirow[t]{4}{*}{ apatite } & $\mathrm{P}$ & 16,67 & 15,49 & 0,9253 & 0,1435 & 0,9511 & 0,9033 & 0,9997 & 38,19 & 0,25 \\
\hline & $\mathrm{Ca}$ & 31,3 & 22,48 & 1,7387 & 0,2845 & 0,9403 & 0,9748 & 1,0002 & 43,79 & 0,36 \\
\hline & $\mathrm{Fe}$ & 0,81 & 0,42 & 0,0099 & 0,0067 & 0,8358 & 0,9817 & 1 & 1,04 & 0,01 \\
\hline & Sum & 83,03 & 100 & 83,03 & 0,62 & & & & & \\
\hline M1a-4 & $\mathrm{O}$ & 34,77 & 62,25 & 0 & 0 & & & & & \\
\hline \multirow[t]{7}{*}{ /biotite } & $\mathrm{Na}$ & 0,22 & 0,27 & 0,0234 & 0,0011 & 0,9617 & 0,5509 & 1,0006 & 0,29 & 0 \\
\hline & $\mathrm{Mg}$ & 0,46 & 0,54 & 0,0427 & 0,0032 & 0,9785 & 0,6984 & 1,005 & 0,76 & 0,01 \\
\hline & Al & 13,79 & 14,64 & 1,3764 & 0,1044 & 0,9436 & 0,8072 & 0,9963 & 26,05 & 0,24 \\
\hline & $\mathrm{Si}$ & 18,38 & 18,75 & 0,5518 & 0,1315 & 0,9656 & 0,7587 & 0,999 & 39,32 & 0,3 \\
\hline & $\mathrm{K}$ & 3,88 & 2,84 & 0,3017 & 0,0326 & 0,9003 & 0,9351 & 1,0004 & 4,67 & 0,05 \\
\hline & $\mathrm{Fe}$ & 1,38 & 0,71 & 0,0167 & 0,0112 & 0,813 & 1 & 1 & 1,78 & 0,01 \\
\hline & Sum & 72,87 & 100 & 72,87 & 0,61 & & & & & \\
\hline M1a-5 & $\mathrm{O}$ & 31,15 & 60,73 & 0 & 0 & & & & & \\
\hline \multirow[t]{7}{*}{ /biotite } & $\mathrm{Mg}$ & 2,37 & 3,04 & 0,2015 & 0,0149 & 0,9972 & 0,6302 & 1,0016 & 3,93 & 0,05 \\
\hline & $\mathrm{Al}$ & 10,32 & 11,93 & 0,9463 & 0,0718 & 0,9617 & 0,7292 & 0,9938 & 19,49 & 0,2 \\
\hline & $\mathrm{Si}$ & 14,43 & 16,03 & 0,4299 & 0,1025 & 0,9842 & 0,735 & 0,9991 & 30,88 & 0,26 \\
\hline & K & 3,26 & 2,6 & 0,2604 & 0,0281 & 0,9182 & 0,9382 & 1,004 & 3,93 & 0,04 \\
\hline & $\mathrm{Ti}$ & 1,18 & 0,77 & 0,0377 & 0,0099 & 0,8477 & 0,9792 & 0,9757 & 1,98 & 0,01 \\
\hline & $\mathrm{Fe}$ & 8,78 & 4,9 & 0,1079 & 0,0724 & 0,8306 & 0,9995 & 1 & 11,29 & 0,08 \\
\hline & Sum & 71,49 & 100 & 71,49 & 0,65 & & & & & \\
\hline \multirow{10}{*}{$\begin{array}{l}\text { M1b-6 } \\
\text { /crandallite } \\
\text { /opal }\end{array}$} & $\mathrm{O}$ & 35,01 & 64,18 & 0 & 0 & & & & & \\
\hline & $\mathrm{Mg}$ & 0,36 & 0,44 & 0,0327 & 0,0024 & 0,9918 & 0,6695 & 1,0032 & 0,6 & 0,01 \\
\hline & Al & 13,6 & 14,78 & 1,3232 & 0,1004 & 0,9565 & 0,7783 & 0,9938 & 25,7 & 0,23 \\
\hline & $\mathrm{Si}$ & 8,81 & 9,2 & 0,2672 & 0,0637 & 0,9789 & 0,7425 & 1,003 & 18,84 & 0,14 \\
\hline & $P$ & 8,48 & 8,03 & 0,3886 & 0,0603 & 0,9417 & 0,762 & 0,9926 & 19,42 & 0,13 \\
\hline & $\mathrm{K}$ & 0,73 & 0,55 & 0,0579 & 0,0063 & 0,9132 & 0,9301 & 1,0065 & 0,88 & 0,01 \\
\hline & $\mathrm{Ca}$ & 2,33 & 1,71 & 0,1265 & 0,0207 & 0,9305 & 0,9515 & 1,0038 & 3,26 & 0,03 \\
\hline & $\mathrm{Fe}$ & 1 & 0,53 & 0,0123 & 0,0082 & 0,8259 & 0,9952 & 1 & 1,29 & 0,01 \\
\hline & $\mathrm{Ba}$ & 2,8 & 0,6 & 0,0393 & 0,019 & 0,6572 & 1,0349 & 1,0013 & 3,13 & 0,01 \\
\hline & Sum & 73,13 & 100 & 73,13 & 0,56 & & & & & \\
\hline \multirow{10}{*}{$\begin{array}{l}\text { M1b-7 } \\
\text { /crandallite } \\
\text { /opal }\end{array}$} & $\mathrm{O}$ & 35,01 & 64,18 & 0 & 0 & & & & & \\
\hline & $\mathrm{Mg}$ & 0,36 & 0,44 & 0,0327 & 0,0024 & 0,9918 & 0,6695 & 1,0032 & 0,6 & 0,01 \\
\hline & Al & 13,6 & 14,78 & 1,3232 & 0,1004 & 0,9565 & 0,7783 & 0,9938 & 25,7 & 0,23 \\
\hline & $\mathrm{Si}$ & 8,81 & 9,2 & 0,2672 & 0,0637 & 0,9789 & 0,7425 & 1,003 & 18,84 & 0,14 \\
\hline & $P$ & 8,48 & 8,03 & 0,3886 & 0,0603 & 0,9417 & 0,762 & 0,9926 & 19,42 & 0,13 \\
\hline & $\mathrm{K}$ & 0,73 & 0,55 & 0,0579 & 0,0063 & 0,9132 & 0,9301 & 1,0065 & 0,88 & 0,01 \\
\hline & $\mathrm{Ca}$ & 2,33 & 1,71 & 0,1265 & 0,0207 & 0,9305 & 0,9515 & 1,0038 & 3,26 & 0,03 \\
\hline & $\mathrm{Fe}$ & 1 & 0,53 & 0,0123 & 0,0082 & 0,8259 & 0,9952 & 1 & 1,29 & 0,01 \\
\hline & $\mathrm{Ba}$ & 2,8 & 0,6 & 0,0393 & 0,019 & 0,6572 & 1,0349 & 1,0013 & 3,13 & 0,01 \\
\hline & Sum & 73,13 & 100 & 73,13 & 0,56 & & & & & \\
\hline M1b-8 & $\mathrm{O}$ & 11,28 & 50,3 & 0 & 0 & & & & & \\
\hline \multirow[t]{6}{*}{ /siderite } & $\mathrm{Mg}$ & 0,35 & 1,01 & 0,0202 & 0,0015 & 1,1013 & 0,3949 & 0,9949 & 0,57 & 0,02 \\
\hline & $\mathrm{Al}$ & 0,45 & 1,19 & 0,0328 & 0,0025 & 1,0624 & 0,524 & 0,9876 & 0,85 & 0,02 \\
\hline & $\mathrm{Ca}$ & 1,08 & 1,92 & 0,0685 & 0,0112 & 1,0394 & 0,9653 & 1,0324 & 1,51 & 0,04 \\
\hline & $\mathrm{Mn}$ & 1,2 & 1,56 & 0,0114 & 0,0114 & 0,917 & 0,9995 & 1,0369 & 1,55 & 0,03 \\
\hline & $\mathrm{Fe}$ & 34,46 & 44,02 & 0,4429 & 0,2971 & 0,9315 & 1,0018 & 1 & 44,33 & 0,88 \\
\hline & Sum & 48,81 & 100 & 48,81 & 0,99 & & & & & \\
\hline M1b-9 & $\mathrm{O}$ & 37,24 & 64,46 & 0 & 0 & & & & & \\
\hline /crandallite & $\mathrm{Mg}$ & 0,29 & 0,33 & 0,0258 & 0,0019 & 0,993 & 0,669 & 1,0031 & 0,47 & 0,01 \\
\hline \multirow[t]{7}{*}{ /opal } & $\mathrm{Al}$ & 15,14 & 15,54 & 1,4763 & 0,112 & 0,9576 & 0,7785 & 0,9932 & 28,6 & 0,24 \\
\hline & $\mathrm{Si}$ & 5,9 & 5,82 & 0,1791 & 0,0427 & 0,98 & 0,7374 & 1,0044 & 12,63 & 0,09 \\
\hline & $\mathrm{P}$ & 11,44 & 10,23 & 0,5379 & 0,0834 & 0,9427 & 0,7809 & 0,9928 & 26,2 & 0,16 \\
\hline & $\mathrm{Ca}$ & 4,03 & 2,78 & 0,2192 & 0,0359 & 0,9316 & 0,9542 & 1,0037 & 5,63 & 0,04 \\
\hline & $\mathrm{Fe}$ & 0,42 & 0,21 & 0,0052 & 0,0035 & 0,8269 & 0,9943 & 1 & 0,54 & 0 \\
\hline & $\mathrm{Ba}$ & 3,14 & 0,63 & 0,0441 & 0,0213 & 0,658 & 1,0328 & 1,0005 & 3,51 & 0,01 \\
\hline & Sum & 77,59 & 100 & 77,59 & 0,55 & & & & & \\
\hline
\end{tabular}


TABLE IV. Continued

\begin{tabular}{|c|c|c|c|c|c|c|c|c|c|c|}
\hline №/mineral & Elt & W\% & interval(95\%) & $\mathrm{A} \%$ & Ix/lstd & Kratio & Z.A.F. & coefs & $\mathrm{Ox} \%$ & Cat\# \\
\hline M1c-10 & $\mathrm{O}$ & 28,46 & 61,1 & 0 & 0 & & & & & \\
\hline /crandallite & $\mathrm{Mg}$ & 1,99 & 2,81 & 0,1612 & 0,012 & 1,0169 & 0,5895 & 0,9999 & 3,3 & 0,05 \\
\hline \multirow[t]{8}{*}{ lopal } & $\mathrm{Al}$ & 7,61 & 9,69 & 0,6758 & 0,0513 & 0,9808 & 0,6914 & 0,9927 & 14,38 & 0,16 \\
\hline & $\mathrm{Si}$ & 9,31 & 11,39 & 0,2822 & 0,0673 & 1,0038 & 0,7267 & 1,0013 & 19,92 & 0,19 \\
\hline & $P$ & 4,29 & 4,76 & 0,1978 & 0,0307 & 0,9658 & 0,744 & 0,9932 & 9,83 & 0,08 \\
\hline & $\mathrm{K}$ & 2,67 & 2,35 & 0,2175 & 0,0235 & 0,9375 & 0,9337 & 1,0074 & 3,22 & 0,04 \\
\hline & $\mathrm{Ca}$ & 1,03 & 0,88 & 0,0574 & 0,0094 & 0,9555 & 0,9467 & 1,0089 & 1,44 & 0,01 \\
\hline & $\mathrm{Fe}$ & 10,05 & 6,18 & 0,1255 & 0,0842 & 0,8501 & 0,9939 & 1 & 12,93 & 0,1 \\
\hline & $\mathrm{Ba}$ & 3,35 & 0,84 & 0,0488 & 0,0236 & 0,6755 & 1,0347 & 1,0136 & 3,74 & 0,01 \\
\hline & Sum & 68,76 & 100 & 68,76 & 0,64 & & & & & \\
\hline \multirow{9}{*}{$\begin{array}{l}\text { M1c-11 } \\
\text { /crandallite } \\
\text { /opal }\end{array}$} & O & 32,4 & 64,38 & 0 & 0 & & & & & \\
\hline & $\mathrm{Mg}$ & 0,38 & 0,5 & 0,0339 & 0,0025 & 0,9947 & 0,659 & 1,0025 & 0,63 & 0,01 \\
\hline & $\mathrm{Al}$ & 11,41 & 13,44 & 1,0971 & 0,0832 & 0,9593 & 0,7683 & 0,9938 & 21,55 & 0,21 \\
\hline & $\mathrm{Si}$ & 7,29 & 8,25 & 0,2233 & 0,0532 & 0,9818 & 0,7472 & 1,0038 & 15,59 & 0,13 \\
\hline & $\mathrm{P}$ & 8,96 & 9,2 & 0,4165 & 0,0646 & 0,9444 & 0,7724 & 0,9928 & 20,53 & 0,14 \\
\hline & $\mathrm{Ca}$ & 3,62 & 2,87 & 0,1975 & 0,0323 & 0,9334 & 0,9543 & 1,0043 & 5,07 & 0,04 \\
\hline & $\mathrm{Fe}$ & 1,22 & 0,69 & 0,0149 & 0,01 & 0,8287 & 0,9939 & 1 & 1,57 & 0,01 \\
\hline & $\mathrm{Ba}$ & 2,93 & 0,68 & 0,0411 & 0,0199 & 0,6593 & 1,0326 & 1,0016 & 3,27 & 0,01 \\
\hline & Sum & 68,21 & 100 & 68,21 & 0,55 & & & & & \\
\hline \multirow{4}{*}{$\begin{array}{l}\text { M1d-12 } \\
\text { /sfalerite }\end{array}$} & S & 28,81 & 50,67 & 0,8703 & 0,2455 & 1,1085 & 0,7761 & 1 & 0 & 0 \\
\hline & $\mathrm{Fe}$ & 1,98 & 2 & 0,0304 & 0,0204 & 0,9713 & 0,9861 & 1,0734 & 0 & 0 \\
\hline & $\mathrm{Zn}$ & 54,86 & 47,32 & 0,8004 & 0,5005 & 0,9311 & 0,9976 & 1 & 0 & 0 \\
\hline & Sum & 85,66 & 100 & 0 & 0 & & & & & \\
\hline \multirow{10}{*}{$\begin{array}{l}\text { M2a-13 } \\
\text { /crandallite } \\
\text { /opal }\end{array}$} & 0 & 34,47 & 64,55 & 0 & 0 & & & & & \\
\hline & $\mathrm{Mg}$ & 0,28 & 0,35 & 0,0253 & 0,0019 & 0,9937 & 0,6581 & 1,0024 & 0,47 & 0 \\
\hline & $\mathrm{Al}$ & 10,08 & 11,19 & 0,9749 & 0,074 & 0,9583 & 0,7685 & 0,9952 & 19,04 & 0 \\
\hline & $\mathrm{Si}$ & 11,96 & 12,77 & 0,3725 & 0,0888 & 0,9807 & 0,7638 & 1,0027 & 25,6 & 0 \\
\hline & $P$ & 7,53 & 7,28 & 0,3426 & 0,0531 & 0,9435 & 0,7546 & 0,9927 & 17,24 & 0 \\
\hline & K & 0,45 & 0,35 & 0,036 & 0,0039 & 0,9151 & 0,9295 & 1,0076 & 0,55 & 0 \\
\hline & $\mathrm{Ca}$ & 2,67 & 2 & 0,1453 & 0,0238 & 0,9325 & 0,9519 & 1,0046 & 3,74 & 0 \\
\hline & $\mathrm{Fe}$ & 1,48 & 0,79 & 0,0181 & 0,0121 & 0,8279 & 0,9942 & 1 & 1,9 & 0 \\
\hline & $\mathrm{Ba}$ & 3,3 & 0,72 & 0,0463 & 0,0224 & 0,6587 & 1,0342 & 1,0019 & 3,68 & 0 \\
\hline & Sum & 72,22 & 100 & 72,22 & 0 & & & & & \\
\hline M2a-14 & $\mathrm{O}$ & 31,12 & 59,06 & 0 & 0 & & & & & \\
\hline \multirow[t]{7}{*}{ /biotite } & $\mathrm{Mg}$ & 4,6 & 5,74 & 0,3671 & 0,0272 & 1,0114 & 0,5858 & 0,9993 & 7,63 & 0 \\
\hline & $\mathrm{Al}$ & 5,87 & 6,61 & 0,5096 & 0,0387 & 0,9754 & 0,6752 & 0,9931 & 11,1 & 0 \\
\hline & $\mathrm{Si}$ & 14,12 & 15,26 & 0,4298 & 0,1024 & 0,9983 & 0,7358 & 0,9994 & 30,2 & 0 \\
\hline & $\mathrm{K}$ & 4,78 & 3,71 & 0,3901 & 0,0422 & 0,9319 & 0,9418 & 1,0064 & 5,76 & 0 \\
\hline & $\mathrm{Ti}$ & 2,23 & 1,41 & 0,0724 & 0,0191 & 0,8607 & 0,9781 & 0,9822 & 3,71 & 0 \\
\hline & $\mathrm{Fe}$ & 15,1 & 8,21 & 0,188 & 0,1262 & 0,8441 & 0,9981 & 1 & 19,43 & 0 \\
\hline & Sum & 77,82 & 100 & 77,82 & 0 & & & & & \\
\hline M2b-15 & $\mathrm{O}$ & 30,98 & 64,66 & 0 & 0 & & & & & \\
\hline /crandallite & $\mathrm{Mg}$ & 0 & 0 & 0 & 0 & 1,0177 & 0,6239 & 1,0015 & 0 & 0 \\
\hline & $\mathrm{Al}$ & 12,9 & 15,96 & 1,2045 & 0,0914 & 0,9816 & 0,7329 & 0,9918 & 24,37 & 0 \\
\hline & $\mathrm{Si}$ & 0,63 & 0,75 & 0,019 & 0,0045 & 1,0048 & 0,7119 & 1,006 & 1,34 & 0 \\
\hline & $\mathrm{P}$ & 12,73 & 13,73 & 0,6212 & 0,0964 & 0,9668 & 0,7945 & 0,9931 & 29,18 & 0 \\
\hline & $\mathrm{Ca}$ & 3,36 & 2,8 & 0,1884 & 0,0308 & 0,9567 & 0,9503 & 1,0094 & 4,71 & 0 \\
\hline & $\mathrm{Fe}$ & 0,47 & 0,28 & 0,0059 & 0,004 & 0,8515 & 0,986 & 1 & 0,61 & 0 \\
\hline & $\mathrm{Ba}$ & 7,5 & 1,82 & 0,107 & 0,0517 & 0,6764 & 1,0306 & 1,0005 & 8,38 & 0 \\
\hline & Sum & 68,58 & 100 & 68,58 & 0 & & & & & \\
\hline M3-17 & 0 & 33,59 & 64,72 & 0 & 0 & & & & & \\
\hline /crandallite & $\mathrm{Mg}$ & 0,12 & 0,15 & 0,0105 & 0,0008 & 0,998 & 0,6555 & 1,0025 & 0,19 & 0 \\
\hline \multirow[t]{6}{*}{ /opal } & $\mathrm{Al}$ & 12,62 & 14,42 & 1,2156 & 0,0922 & 0,9625 & 0,767 & 0,9932 & 23,85 & 0 \\
\hline & $\mathrm{Si}$ & 4,91 & 5,39 & 0,1503 & 0,0358 & 0,9851 & 0,7397 & 1,005 & 10,51 & 0 \\
\hline & $\mathrm{P}$ & 11,31 & 11,25 & 0,536 & 0,0831 & 0,9477 & 0,7859 & 0,9928 & 25,91 & 0 \\
\hline & $\mathrm{K}$ & 0,13 & 0,1 & 0,0103 & 0,0011 & 0,9193 & 0,9292 & 1,0093 & 0,16 & 0 \\
\hline & $\mathrm{Ca}$ & 3,41 & 2,63 & 0,1868 & 0,0306 & 0,9367 & 0,9528 & 1,0049 & 4,78 & 0 \\
\hline & $\mathrm{Fe}$ & 0,93 & 0,51 & 0,0114 & 0,0077 & 0,8319 & 0,9929 & 1 & 1,19 & 0 \\
\hline
\end{tabular}


TABLE IV. Continued

\begin{tabular}{|c|c|c|c|c|c|c|c|c|c|c|}
\hline №/mineral & Elt & $\mathrm{W} \%$ & interval(95\%) & $\mathrm{A} \%$ & Ix/lstd & Kratio & Z.A.F. & coefs & $\mathrm{Ox} \%$ & Cat\# \\
\hline & $\mathrm{Ba}$ & 3,69 & 0,83 & 0,052 & 0,0251 & 0,6618 & 1,0325 & 1,0012 & 4,12 & 0 \\
\hline & Sum & 70,71 & 100 & 70,71 & 0 & & & & & \\
\hline M3-18 & $\mathrm{O}$ & 33,42 & 63,98 & 0 & 0 & & & & & \\
\hline /crandallite & $\mathrm{Mg}$ & 0,16 & 0,2 & 0,0143 & 0,0011 & 0,9789 & 0,6911 & 1,0048 & 0,26 & 0 \\
\hline \multirow[t]{8}{*}{ lopal } & $\mathrm{Al}$ & 13,2 & 14,98 & 1,3066 & 0,0991 & 0,944 & 0,8033 & 0,9958 & 24,94 & 0 \\
\hline & Si & 15,29 & 16,68 & 0,4554 & 0,1086 & 0,966 & 0,7527 & 0,9998 & 32,72 & 0 \\
\hline & $P$ & 2,56 & 2,53 & 0,1096 & 0,017 & 0,9292 & 0,7178 & 0,992 & 5,86 & 0 \\
\hline & $\mathrm{K}$ & 0,02 & 0,01 & 0,0012 & 0,0001 & 0,9007 & 0,9306 & 1,0023 & 0,02 & 0 \\
\hline & $\mathrm{Ca}$ & 0,65 & 0,5 & 0,035 & 0,0057 & 0,9176 & 0,9546 & 1,0017 & 0,91 & 0 \\
\hline & $\mathrm{Fe}$ & 1,84 & 1,01 & 0,0223 & 0,0149 & 0,8134 & 1,0007 & 1 & 2,36 & 0 \\
\hline & $\mathrm{Ba}$ & 0,53 & 0,12 & 0,0074 & 0,0036 & 0,6478 & 1,0413 & 1,0031 & 0,59 & 0 \\
\hline & Sum & 67,67 & 100 & 67,67 & 0 & & & & & \\
\hline M3-19 & 0 & 14,31 & 50 & 0 & 0 & & & & & \\
\hline /dolomite & $\mathrm{Mg}$ & 10,04 & 23,07 & 0,8159 & 0,0605 & 1,0031 & 0,6363 & 0,9956 & 16,64 & 0 \\
\hline \multirow[t]{3}{*}{ lopal } & $\mathrm{Ca}$ & 18,64 & 25,99 & 1,0296 & 0,1685 & 0,9419 & 0,9869 & 1,0006 & 26,08 & 0 \\
\hline & $\mathrm{Fe}$ & 0,93 & 0,93 & 0,0114 & 0,0076 & 0,8374 & 0,9812 & 1 & 1,2 & 0 \\
\hline & Sum & 43,91 & 100 & 43,91 & 0 & & & & & \\
\hline M4-20 & 0 & 12,24 & 50 & 0 & 0 & & & & & \\
\hline \multirow[t]{4}{*}{ /siderite } & $\mathrm{Mg}$ & 2,49 & 6,7 & 0,1474 & 0,0109 & 1,0924 & 0,4067 & 0,9947 & 4,13 & 0 \\
\hline & $\mathrm{Ca}$ & 1,28 & 2,08 & 0,0799 & 0,0131 & 1,0306 & 0,9654 & 1,0301 & 1,79 & 0 \\
\hline & $\mathrm{Fe}$ & 35,22 & 41,22 & 0,4489 & 0,3012 & 0,923 & 1,0017 & 1 & 45,3 & 0 \\
\hline & Sum & 51,22 & 100 & 51,22 & 0 & & & & & \\
\hline M4-21 & $\mathrm{O}$ & 32,99 & 64,9 & 0 & 0 & & & & & \\
\hline /dolomite & $\mathrm{Al}$ & 12,03 & 14,03 & 1,1545 & 0,0876 & 0,9652 & 0,762 & 0,9932 & 22,73 & 0 \\
\hline \multirow[t]{6}{*}{ lopal } & Si & 4,12 & 4,62 & 0,1267 & 0,0302 & 0,9879 & 0,74 & 1,0055 & 8,82 & 0 \\
\hline & $P$ & 11,92 & 12,11 & 0,5698 & 0,0884 & 0,9504 & 0,7915 & 0,9929 & 27,3 & 0 \\
\hline & $\mathrm{Ca}$ & 3,68 & 2,89 & 0,2021 & 0,0331 & 0,9396 & 0,9528 & 1,0055 & 5,15 & 0 \\
\hline & $\mathrm{Fe}$ & 0,87 & 0,49 & 0,0107 & 0,0072 & 0,8347 & 0,9918 & 1 & 1,12 & 0 \\
\hline & $\mathrm{Ba}$ & 4,18 & 0,96 & 0,0589 & 0,0285 & 0,6638 & 1,0317 & 1,0011 & 4,66 & 0 \\
\hline & Sum & 69,79 & 100 & 69,79 & 0 & & & & & \\
\hline M4-22 & 0 & 31,09 & 64,44 & 0 & 0 & & & & & \\
\hline /dolomite & $\mathrm{Al}$ & 11,58 & 14,23 & 1,1082 & 0,0841 & 0,9643 & 0,7624 & 0,9935 & 21,88 & 0 \\
\hline \multirow[t]{6}{*}{ lopal } & $\mathrm{Si}$ & 6,83 & 8,06 & 0,2078 & 0,0495 & 0,9869 & 0,7387 & 1,0036 & 14,61 & 0 \\
\hline & $P$ & 8,53 & 9,13 & 0,3958 & 0,0614 & 0,9495 & 0,7678 & 0,9928 & 19,54 & 0 \\
\hline & $\mathrm{Ca}$ & 2,93 & 2,43 & 0,1609 & 0,0263 & 0,9386 & 0,9531 & 1,0057 & 4,1 & 0 \\
\hline & $\mathrm{Fe}$ & 1,3 & 0,77 & 0,016 & 0,0108 & 0,8338 & 0,9925 & 1 & 1,67 & 0 \\
\hline & $\mathrm{Ba}$ & 3,89 & 0,94 & 0,0549 & 0,0266 & 0,6632 & 1,0335 & 1,0018 & 4,35 & 0 \\
\hline & Sum & 66,15 & 100 & 66,15 & 0 & & & & & \\
\hline M5-23 & 0 & 31,8 & 64,27 & 0 & 0 & & & & & \\
\hline /dolomite & $\mathrm{Al}$ & 12,03 & 14,41 & 1,1566 & 0,0878 & 0,9633 & 0,7663 & 0,9934 & 22,72 & 0 \\
\hline \multirow[t]{7}{*}{ lopal } & $\mathrm{Si}$ & 6,08 & 7 & 0,1854 & 0,0442 & 0,9859 & 0,7398 & 1,0041 & 13 & 0 \\
\hline & $P$ & 9,37 & 9,78 & 0,439 & 0,0681 & 0,9485 & 0,7755 & 0,9929 & 21,47 & 0 \\
\hline & K & 0,81 & 0,67 & 0,065 & 0,007 & 0,9201 & 0,9299 & 1,0085 & 0,98 & 0 \\
\hline & $\mathrm{Ca}$ & 2,82 & 2,27 & 0,154 & 0,0252 & 0,9376 & 0,9507 & 1,005 & 3,94 & 0 \\
\hline & $\mathrm{Fe}$ & 1,32 & 0,76 & 0,0162 & 0,0109 & 0,8327 & 0,9929 & 1 & 1,69 & 0 \\
\hline & $\mathrm{Ba}$ & 3,51 & 0,83 & 0,0494 & 0,0239 & 0,6624 & 1,0325 & 1,0017 & 3,92 & 0 \\
\hline & Sum & 67,73 & 100 & 67,73 & 0 & & & & & \\
\hline M5-24 & $\mathrm{O}$ & 34,13 & 64,67 & 0 & 0 & & & & & \\
\hline /dolomite & $\mathrm{Al}$ & 12,52 & 14,07 & 1,211 & 0,0919 & 0,9611 & 0,7702 & 0,9935 & 23,66 & 0 \\
\hline \multirow[t]{7}{*}{ lopal } & $\mathrm{Si}$ & 6,12 & 6,61 & 0,1879 & 0,0448 & 0,9837 & 0,744 & 1,0046 & 13,1 & 0 \\
\hline & $P$ & 10,8 & 10,57 & 0,5084 & 0,0789 & 0,9463 & 0,781 & 0,9928 & 24,74 & 0 \\
\hline & $\mathrm{K}$ & 0,38 & 0,3 & 0,0304 & 0,0033 & 0,9179 & 0,9294 & 1,0085 & 0,46 & 0 \\
\hline & $\mathrm{Ca}$ & 3,15 & 2,38 & 0,1718 & 0,0281 & 0,9353 & 0,9521 & 1,0046 & 4,4 & 0 \\
\hline & $\mathrm{Fe}$ & 1,21 & 0,66 & 0,0149 & 0,01 & 0,8305 & 0,9936 & 1 & 1,56 & 0 \\
\hline & $\mathrm{Ba}$ & 3,39 & 0,75 & 0,0477 & 0,0231 & 0,6607 & 1,033 & 1,0015 & 3,78 & 0 \\
\hline & Sum & 71,71 & 100 & 71,71 & 0 & & & & & \\
\hline
\end{tabular}

